\title{
Complexity drivers in manufacturing companies: a literature review
}

\author{
Wolfgang $\operatorname{Vogel}^{1}$ (D) Rainer $\operatorname{Lasch}^{1}$
}

Received: 21 February 2016/ Accepted: 1 November 2016/Published online: 24 November 2016

(C) The Author(s) 2016. This article is published with open access at Springerlink.com

\begin{abstract}
Increasing complexity in manufacturing companies has been one of the biggest issues during the last years. Companies in high-technology marketplaces are confronted with technology innovation, dynamic environmental conditions, changing customer requirements, globalization of markets and competitions as well as market uncertainty. Manufacturing companies can't escape these trends, which induce an increasing amount of complexity. Reasons for this phenomenon are internal and external sources of complexity so-called complexity drivers. Identifying, analyzing and understanding complexity drivers are the first step for complexity management's development and implementation. Complexity management is a strategic issue for companies to be competitive. The purpose of this literature review is to provide a general overview regarding complexity drivers in manufacturing companies. The different definitions of complexity drivers are described, and a new overall definition of complexity drivers is presented. Furthermore, the existing approaches for complexity driver's identification, operationalization and visualization are identified and specified. For complexity driver's clustering, a superior classification system was developed based upon existing classification systems in the literature. The literature review was done by systematically analyzing and collecting existing literature and
\end{abstract}

Wolfgang Vogel

Wolfgang.Vogel@mailbox.tu-dresden.de

Rainer Lasch

rainer.lasch@tu-dresden.de

1 Department of Business Management and Economics, Chair of Business Management, esp. Logistics, Technische Universität Dresden, Mommsenstr. 13, 01062 Dresden, Germany reveals gaps according to methodology and issue. Existing literature reviews are only focused on specific issues, such as logistics or supply chain management, and do not point out the applied research methodology in detail. A general overview regarding complexity drivers in manufacturing companies and along the value chain does not exist yet.

Keywords Complexity · Complexity management . Complexity drivers $\cdot$ Literature review

\section{Introduction}

Technology innovation, dynamic environmental conditions, changing customer requirements, market's globalization and market uncertainty are trends that manufacturing companies cannot escape and that often lead to an increase in complexity $[86,177,198]$. Within the last decades, complexity has increased continuously in many industries [242]. This is one of the biggest challenges that manufacturing companies have to face today [71]. The reasons are internal and external sources of complexity socalled complexity drivers.

The origin of the term complexity comes from the Latin word "complexus", which means "extensive, interrelated, confusing, entwined or twisted together" [71, 88, 103, 199]. This is similar to the Oxford Dictionaries [182] definition of "complex": Something is complex if it is "consisting of many different and connected parts" and it is "not easy to analyze or understand". Complexity is directly connected with a system and his terminology $[117,203,269]$. In the literature, complexity is defined as part of system's property [154]. GellMann [85] and Luhmann [163] argue that the definition of complexity always needs a description of system's level of 
detail. The approaches of the system theory provide an opportunity to divide a system in several subsystems and support the determination of system's level of detail [260]. The system theory can be attributed to the natural science, whereby control und adjustment operations are considered in a system's context [15]. For the term system, several definitions are existing in the literature. Göpfert [93] defines a system as an unit, consisting of several parts. Ulrich [269] and Patzak [195] extend this definition and describe a system as an entity of elements, which are related to each other or concrete relation can be made through the elements. Ulrich [269] argues that the elements and their relations are significant for system's complexity, and in dynamic systems the system can suppose a high amount of different conditions. Thus, complexity would be described by an amount of variable or elements [103].

In principle, a system is ever surrounded by an environment and can be isolated by the system boundary [260]. However, the system and its complexity are influenced by the environment [269].

Complexity and systems are consisting of the interaction between elements and relations [15, 163]. Thereby, the elements are representing the tangible parts of a system, whereas the connection between the elements is described by relations [260]. Consequently, a system's complexity depends on the amount of existing parts or components, the connections between them and the diversity of these relations and elements [71, 163]. In this context, Patzak [195] and Meyer [174] describe elements' diversity as variety and relations' diversity as connectivity. Bronner [36] extends this definition by consideration of system's $d y$ namic and comprises the variation of system's behavior over time.

Complexity has been discussed in several fields of research such as physics, biology, chemistry, mathematics, computer science, economics, engineering and management as well as philosophy [30, 120]. Thus, in scientific literature, there are many different definitions for the term "complexity" because the meaning is vague and ambiguous. There is no explicit, universal and widely accepted definition $[39,71,215]$. As a result, the term "complexity" is often used synonymously with the term "complicated" [88]. Meijer [172] argues that "complexity is in the eye of the beholder". Complexity is driven by the sensation or perspective of an individual. What is complex to someone might not be complex to another [103, 158].

There are two types of complexity: good and bad. The good type of complexity is necessary. It helps a company to gain market share and is value adding. On the other side, bad complexity brings little value, reduces revenue and causes excessive costs [71, 120]. Colwell [55] defines thirty-two types of complexity in twelve different areas and disciplines such as structural, functional, technical, computational and operational complexity. Götzfried [94] describes seventeen definitions of complexity in four different research fields such as systems theory, organizational theory, product design and operations management. In the literature, increasing complexity is often related to increasing costs [174]. Managing a system's complexity requires an optimum fit between internal and external complexity [240, 272]. The complexity management comprises the application of the mentioned complexity consideration with the aim of a target-oriented complexity design [174]. Schuh [240] argues further that the complexity management comprises four tasks: designing the necessary variety, handling variety-increasing factors, reducing variety and controlling complex systems [272].

Generally, complexity is caused by internal and external factors [174]. Meyer [174] defines these factors as complexity drivers. According to the Business Dictionary [47], a driver causes a condition or decision or has an effect on elements or a system. Complexity drivers lead to an increased level of complexity in comparison with an initial situation [174]. Furthermore, complexity drivers can cause turbulences and new functional models in a system [150].

For complexity's operationalization, Schuh [240] argues that it can only be realized by several complexity factors, which interact with each other.

Identifying, analyzing and understanding complexity drivers as main elements related to complexity are the first step to develop and implement a clear strategy to handle complexity [177, 255]. Without an idea of complexity drivers, it would be difficult to develop an effective complexity strategy [255]. Heydari and Dalili [116] argue that a research in complexity management needs to know what the key drivers of complexity in a system are. The management of complexity is a strategic issue for companies to be competitive [44, 177, 240]. In the study "Managing Complexity in Automotive Engineering". Erkayhan [72] concludes that the complexity drivers are the main adjusting levers for improvements of the company's success. Thus, complexity drivers play a significant role for complexity management, because they describe a system's complexity and help to evaluate and handle it.

Previous literature studies about complexity drivers have been done by Meyer [174], Serdarasan [255, 256] and Wildemann and Voigt [289] and comprise a time period of 20 years (1991-2011). They cover complexity drivers on specific issues such as logistics, supply chains and general in manufacturing companies. In total, 99 literature sources such as articles, books and $\mathrm{PhD}$ theses in the research period between 1991 and 2011 form their research. Furthermore, 281 complexity drivers are identified in total. Although these literature studies cover a lot of literature sources and complexity drivers in the referred fields, a systematic, explicit and reproducible method for 
identification, evaluation and synthesizing the existing literature about complexity drivers is not described [78]. For example, the authors in the previous literature studies have not described specific research questions, databases, search terms and synthesizing methods. In addition, not all authors provide a comparison between their findings and the findings of other literature sources. However, these are essential to determine the current state of knowledge about a particular research issue in a literature review. So they do not fulfill the requirements of a literature review in general.

This paper's purpose is a literature review of complexity drivers in manufacturing companies and along the value chain, including the fields product development, procurement/purchasing, logistics, production, order processing/ distribution/sale, internal supply chain and remanufacturing, which fulfills the mentioned requirements.

The contribution of this review is to develop additional knowledge for science and practice by describing what is currently known on the issue of complexity drivers. From scientific perspective, this literature review presents a current state of the art about complexity drivers and gives the researcher a first insight and general understanding about complexity drivers, before starting a research project in this field. It closes a currently existing gap in scientific literature. The literature review can be used for a dissertation or research proposal to give an overview about the issue of complexity drivers and is helpful for researchers, who have no prior knowledge in this field. Further, it helps the researcher to avoid time-wasting and research effort by "reinventing the wheel". Within this research, the gaps for future research are pointed out. Based on this review, researchers can build new ideas and theories for their own research. The research methodology, including research questions, databases and synthesizing methods, is described in detail to increase transparency. This enables the researcher to reproduce the findings. The literature review provides a comprehensive survey of significant literature (e.g., academic journal articles, books, essays, $\mathrm{PhD}$ theses, conference proceedings) and their results, based on analyzing, synthesizing and summarizing the existing literature. Furthermore, the different literature sources and the trends of complexity drivers in the literature and in the different fields (general in manufacturing companies and/or along the value chain) over the last 25 years are described. The trends show the researcher how essential the topic complexity drivers is in the literature and that it is thus interesting for future research. However, interesting topics for academic people do not have to be important for practice. To avoid this trade-off, we also include the practical perspective in our point of view. In addition, different definitions of complexity drivers are analyzed and described. A new overall definition of complexity drivers is presented. Furthermore, the existing approaches for complexity driver's identification, operationalization and visualization are identified and specified according to their focus. The identified complexity drivers were clustered in aggregated complexity driver's main categories according to their characteristics to provide a general classification system without overlaps. From practical perspective, this literature review gives the practitioner a first insight and understanding about the phenomena of complexity drivers and their importance. In several empirical studies, for example from Wildemann and Voigt [289], Gießmann [88] and Gießmann and Lasch [89], the issue complexity in companies and its drivers were analyzed. The result was that companies are aware of complexity and some of its causes but often do not know how to handle it, because of a lack of specific methods or tools for complexity driver's identification, operationalization or visualization. This study answers the following manager's questions "What are complexity drivers?" "Why they are so important for me?" and "How can I identify, operationalize and visualize complexity drivers?" by providing an overall definition about complexity drivers and an overview about the existing approaches for complexity driver's identification, operationalization and visualization. Beyond, the practitioner gets an overall selection of different approaches and their focuses and can choose the right one for solving his task or problem. Furthermore, a list of theoretical existing complexity drivers, which were found in the literature, are described, so the management has a general overview about complexity drivers and can compare these findings with their own complexity drivers to identify communalities and differences as well as get a first indication. This review collects existing approaches for complexity driver's identification, operationalization and visualization based on the literature. Therefore, it can be used as a basis to gain first implications about complexity drivers, their identification, operationalization and visualization. Further research will be needed to create helpful advice for practitioners to detect complexity issues as well as to present methodological support to detect causes of complexity and their effects.

This literature review is structured as follows: In Sect. 2, the paper gives an overview about the research method. Some definitions of literature reviews are disclosed, and a framework for constructing a literature review is specified. Section 3 presents the literature review about complexity drivers with an overview about different definitions and approaches for identification, operationalization and visualization. The most discussed complexity drivers in manufacturing companies and along the value chain are described. Section 4 concludes the paper and closes the research gap with implication for future research. 


\section{Research method}

\subsection{Research methodology and boundary definition}

The aim of this study is a systematic, explicit and reproducible literature review about complexity drivers in manufacturing companies and along the value chain, which provides definitions of complexity drivers, and existing approaches for complexity driver's identification, operationalization and visualization. The existing literature was identified, evaluated and synthesized by using qualitative data analysis to point out the existing literature sources and their focuses as well as the trends and issues. The literature results are compared with each other. To provide a comprehensive literature review, we used the methodology of Fink [78] and structured our article according to him. Literature reviews have been used for many years in scientific research and scholar findings. They are a long-standing tradition, but the definitions are tight [43]. Fink [78] defines a literature review as a "systematic, explicit and reproducible method for identifying, evaluating, and synthesizing the existing body of completed and recorded work produced by researchers, scholars, and practitioners". Brewerton and Millward [34] describe a literature review as a content analysis that uses qualitative and quantitative techniques to find structural and content criteria. According to Meredith [173], a literature review is a "summary of the existing literature by finding research focus, trends, and issues". Within this paper, we follow the definitions of Fink [78], Brewerton and Millward [34] and Meredith [173].

Fink [78] divides a literature review into seven tasks. The first step is selecting the research questions. Research questions are precisely stated questions, which guide the literature review. The next step is to select the required sources such as bibliographic or article databases, Web sites and other sources to determine relevant literature. Before starting the literature review, the researcher has to define the search terms. To review the databases and search terms, the researcher should ask experts or other researchers. The next steps are applying practical and methodological screening criteria to identify and select the relevant literature from the entity of found literature. To reject irrelevant articles, the researcher has to screen the literature by setting practical and methodological criteria.

According to Fink [78], the first step is to define the research questions. The benefit of research questions is that they already contain the words the reviewer needs to search for online to find relevant literature. These words or search terms are called key words, descriptors or identifiers [76].

For this literature review, we determined the following research questions including the relevant key word "complexity driver":

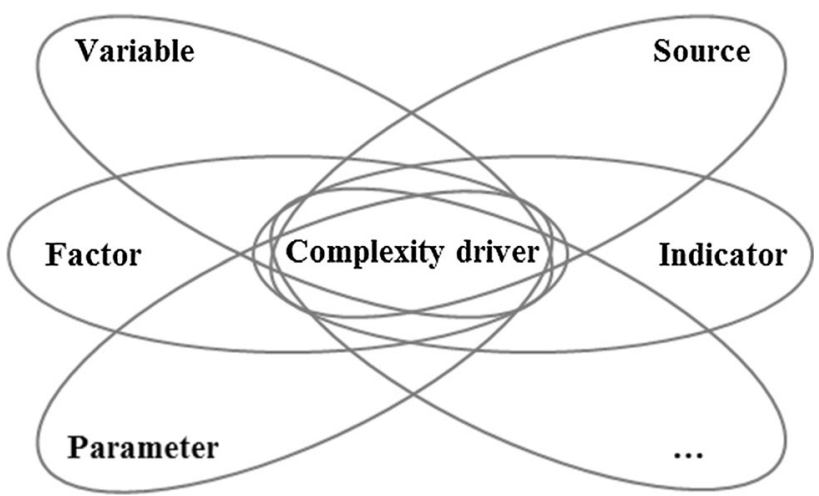

Fig. 1 Paraphrases of the term complexity driver and their intersection

RQ1: What are the different definitions of complexity drivers that currently exist in manufacturing companies and along the value chain?

RQ2: What methods are applied in the literature for complexity driver's identification, operationalization and visualization?

RQ3: What complexity drivers occur in manufacturing companies and along the value chain?

Before conducting a literature research, it is necessary to define the right search terms and databases. The search terms are based on the words that frame the research questions. In the literature, several paraphrases for complexity driver exist. These paraphrases are usually a combination of the terms factor, indicator, source, parameter, variable, symptom, phenomenon, dimension, force and property and the term complexity driver (see Sect. 3.2). When comparing the meaning of these different word combinations, it can be seen that the lowest common denominator is complexity driver (see Fig. 1). Thus, we limited our literature research to the search term complexity driver.

A researcher must use a "particular grammar and logic" to conduct a search that will acquire the appropriate publications [78]. One possibility is to combine the key words and other terms with Boolean operators such as AND, OR and NOT. Further, the operator NEAR can be used to identify the literature where the keywords have a close connection to each other. The application of Boolean operators depends on the specific database. To extend the amount of relevant literature, it is also necessary to search in different languages. In our research, we search in English- and German-language literature. This has two reasons: First, English is the global language and applied in the scientific world to provide research findings worldwide. Second, during our literature research we started with English-language sources and found some literature sour- 
Table 1 General framework of literature collection

\begin{tabular}{|c|c|c|c|c|}
\hline Focus & Database & Search terms & Date & Results \\
\hline $\begin{array}{l}\text { - General in manufacturing } \\
\text { companies }\end{array}$ & EBSCOhost & $\begin{array}{l}\text { ('Komplexitätstreiber' OR (Treiber N3 Komplexität)) AND ... } \\
\text { ('complexity driver*' OR (driver* N3 complexity)) AND ... }\end{array}$ & $\begin{array}{l}\text { April \& } \\
\text { May '16 }\end{array}$ & 401 \\
\hline - Product Development & Emerald & $\begin{array}{l}\text { ("Komplexitätstreiber" OR "Treiber d* Komplexität") AND ... } \\
\text { ("complexity driver" OR "driver of complexity") AND ... }\end{array}$ & $\begin{array}{l}\text { April \& } \\
\text { May'16 }\end{array}$ & 44 \\
\hline - Procurement / Purchasing & $\begin{array}{l}\text { GENIOS / } \\
\text { WISO }\end{array}$ & $\begin{array}{l}\text { ("Komplexitätstreiber" OR (Treiber ndj3 Komplexität)) AND ... } \\
\text { ("complexity driver*" OR (driver* ndj3 complexity)) AND ... }\end{array}$ & $\begin{array}{l}\text { April \& } \\
\text { May '16 }\end{array}$ & 1001 \\
\hline - Logistics & Google Scholar & $\begin{array}{l}\text { ("Komplexitätstreiber" OR "Treiber d* Komplexität") AND ... } \\
\text { ("complexity driver*" OR "driver* of complexity") AND ... }\end{array}$ & May ‘16 & 3234 \\
\hline - Production & IEEE Xplore & $\begin{array}{l}\text { ("Komplexitätstreiber" OR (Treiber NEAR/3 Komplexität)) AND ... } \\
\text { (complexity NEAR/3 driver) AND ... }\end{array}$ & May ‘16 & 2203 \\
\hline $\begin{array}{l}\text { - Order Processing / } \\
\text { Distribution / Sale }\end{array}$ & JSTOR & $\begin{array}{l}\text { ("Komplexitätstreiber" OR ("Treiber Komplexität" 5)) AND ... } \\
\text { ("complexity driver" OR ("driver complexity" 5)) AND ... }\end{array}$ & $\begin{array}{l}\text { May \& } \\
\text { June '16 }\end{array}$ & 146 \\
\hline - Supply Chain & ScienceDirect & $\begin{array}{l}\text { ("Komplexitätstreiber*" OR (Treiber W/3 Komplexität)) AND ... } \\
\text { (complexity W/3 driver*) AND ... }\end{array}$ & $\begin{array}{l}\text { May \& } \\
\text { June ' } 16\end{array}$ & 1726 \\
\hline \multirow[t]{2}{*}{ - Remanufacturing } & SpringerLink & $\begin{array}{l}\text { (Komplexitätstreiber OR (Treiber NEAR/3 Komplexität)) AND ... } \\
\text { (Complexity NEAR/3 driver*) AND ... }\end{array}$ & $\begin{array}{l}\text { May \& } \\
\text { June '16 }\end{array}$ & 2670 \\
\hline & & & Total: & 11425 \\
\hline
\end{tabular}

ces with references to German-language sources. This was another reason to extend the research in German-language literature.

According to Saunders, Lewis and Thornhill [219] the finalized search terms are identified through an iterative cycle starting with one key word and adding more in the process of research in order to summarize all necessary and possible literature and results. Furthermore, the search terms are defined in English and German and then formulated more general to extend the results and to prevent the elimination of important articles. We started our research by using the key words "Komplexitätstreiber" and "complexity driver" and formulated the search term "Komplexitätstreiber OR complexity driver". After reviewing the found literature, we found out that a lot of sources also used the term "Treiber der Komplexität" or "driver of complexity," so we added these terms to our first search term and received the new term "Komplexitätstreiber OR Treiber der Komplexität OR complexity driver OR driver of complexity". During the following search process, it became clear that sometimes these keywords are separated by other words so we implemented the NEAR operator to cover all existing and relevant literature. The finalized search terms are described in Table 1.

After defining the right search terms, a researcher must examine all sources systematically by using online bibliographic or article databases. Databases are often specialized in a specific research area. The research for this paper was performed in English and German by using the following eight English and German databases: EBSCOhost,
Emerald, GENIOS/WISO, Google Scholar, IEEE Xplore, JSTOR, ScienceDirect and SpringerLink.

The used databases were also defined through an iterative cycle. In our research, we started by using the databases EBSCOhost, JSTOR, GENIOS/WISO and Google Scholar. EBSCOhost and JSTOR are one of the biggest databases for academic research and connected with numerous other databases. During our research process on Google Scholar, some literature sources were found on other specific databases such as Emerald, IEEE Xplore, ScienceDirect and SpringerLink. Thus, these databases were also included in the research process.

Table 1 shows the general framework of our literature collections including the research focus, applied databases and search terms. Furthermore, the framework contains the results and search dates at an aggregate level to provide first insights. In our research, the time period was restricted between January 01, 1900, and December 31, 2015. The different frameworks with all precise search terms, results and searching dates are shown in "Appendix" (Table 13).

\subsection{Research segmentation and overview}

The search resulted in 11,425 literature sources including research papers from journals, conference proceedings, working papers, books, essays and $\mathrm{PhD}$ theses. However, several literature sources are found repeatedly.

According to Fink [78], literature research and analysis always accumulate many publications, but only a few are 


\begin{tabular}{|c|c|c|c|c|c|c|c|}
\hline \multirow{2}{*}{\multicolumn{3}{|c|}{$\begin{array}{c}\text { Categories } \\
\text { (combined with } \boldsymbol{R} \boldsymbol{Q} \text { ) }\end{array}$}} & \multicolumn{5}{|c|}{ Identified literature sources with Author's name(s) } \\
\hline & & & Source \#1 & Source \#2 & Source \#3 & $\ldots$ & Source \#n \\
\hline \multicolumn{8}{|c|}{ Definition of complexity drivers $(\boldsymbol{R} Q \mathbf{1})$} \\
\hline \multirow{3}{*}{$\begin{array}{l}\text { Methods for } \\
\text { complexity } \\
\text { drivers' ... } \\
\text { (RQ2) }\end{array}$} & & ... identification & & & & & \\
\hline & & ... operationalization & & & & & \\
\hline & & $\ldots$ visualization & & & & & \\
\hline \multirow{8}{*}{$\begin{array}{l}\text { Complexity } \\
\text { drivers in } \\
\text { manufacturing } \\
\text { companies } \\
(\boldsymbol{R Q 3})\end{array}$} & & General & & & & & \\
\hline & & Product development & & & & & \\
\hline & & Procurement / Purchasing & & & & & \\
\hline & $\Xi$ & Logistics & & & & & \\
\hline & $\begin{array}{l}\dot{U} \\
\cong\end{array}$ & Production & & & & & \\
\hline & $s^{\pi}$ & Order processing / Distribution / Sale & & & & & \\
\hline & & Supply chain & & & & & \\
\hline & & Remanufacturing & & & & & \\
\hline
\end{tabular}

Fig. 2 Synthesis matrix for literature's synthesizing

relevant. Consequently, it is necessary to screen and synthesize the results.

In this paper, the researched literature was synthesized based on the qualitative content analysis and the aforementioned research questions. The content analysis is used to analyze the literature and to identify the occurrences of specified information systematically. Within the qualitative content analysis, the information is extracted, formatted and evaluated to answer the research questions. The most important aspect is the extraction of the information to gain the required information. Extraction means to read the text, separating the text in different parts, and to decide which of the given text parts contain information that is relevant for the researcher. The relevant information is then assigned to previously defined categories [92]. In the qualitative content analysis, this assignment is called coding and is induced by a coding unit. The coding unit is a text passage, which is connected to a certain category or content. The assignment to the defined categories is performed by the researcher, called coder [152]. However, the researcher and his understanding and interpretation influence the extraction and text interpretation [92, 152]. When the coding process is done by more than one researcher, a common understanding and interpretation is required [152]. The defined categories are connected with the research questions and are not fixed. During the extraction process, they can be altered and new categories can also be added. As a result of the extraction, a vast amount of data are collected which can be used for information formatting and evaluation to answer the research questions. For information evaluation, the researcher compares the different literature sources to identify communalities and differences [92].

For analyzing and synthesizing the literature in our research, we followed the approach of the qualitative content analysis and defined in the first step twelve categories based on our three research questions. The categories were implemented in a synthesis matrix (see Fig. 2). The synthesis matrix helps the researcher to organize the identified literature and their different contents on an issue.

In the next step, we started the extraction process by screening the title and abstracts of the identified papers, books, etc. and eliminate sources without focus in manufacturing companies or the value chain. For example, papers focused on financial, insurance or biological issues were eliminated. Furthermore, we excluded all papers that were found multiple times. Within this procedure, the total amount of found literature sources could be reduced significantly.

Then, we started our detailed literature analysis by searching for the key words "complexity driver" or "driver of [...] complexity" and analyzed the content around the key words. The key words were highlighted in the text, and we made notes about our first impressions and thoughts. Afterward, we read all data repeatedly to achieve an overview of the whole content and separated the text in different parts 
Table 2 List of journals, books and papers published during the period 1991-2015

\begin{tabular}{llc}
\hline Literature source & Time horizon & Number of publications \\
\hline Journals & $1991-2015$ & 68 \\
Books & $1993-2015$ & 41 \\
Essay & $1991-2015$ & 41 \\
PhD theses & $1991-2015$ & 55 \\
Conference proceedings & $2010-2015$ & 13 \\
Working papers & $2000-2012$ & 11 \\
Newspaper & $1994-2009$ & 4 \\
Internet (Web sites) & $2005-2014$ & 2 \\
Total & & 235
\end{tabular}

regarding their content. The parts with relevant information about complexity drivers were assigned to the previously defined categories in our synthesis matrix. The assignment of a specific information to a certain category (coding) was induced by the particular text passage (coding unit). Parts without relevant information were ignored. As a result of our extraction process, a vast amount of data from 235 different literature sources were collected in a table to answer our research questions. For information evaluation, we compared the found information in each category to identify communalities or differences.

The synthesizing process resulted finally in 235 relevant papers. These papers were published in journal articles (68), books (41), essays (41), PhD theses (55), conference proceedings (13), working papers (11), newspaper (4) and Web sites (2) in the field of complexity drivers in the time period 1991-2015 (see Table 2).

Before 1991, no relevant literature sources in regard to the issue complexity drivers were found in our research.

One reason could be attributed to the development of the scientific research in the field complexity management [90]. According to Gießmann and Lasch [90], complexity management's development process can be separated in three steps: variant management, complexity management in a narrower sense and integrated complexity management (see Fig. 3). These steps do not appear strictly in sequence but also parallel.

Due to a change from seller's to buyer's market, the companies extend their product portfolio. In consequence, the product portfolio reached a volume that could hardly be managed by the companies [90]. Therefore, variant management was developed to handle product's complexity. Variant management's objective is to combine variant's diversity and profitability [82, 90]. Product's amount and property was one complexity driver. Within the complexity management, the focus lays more and more upon the processes. Processes were identified as a further complexity driver. In the third step, the upstream and downstream processes and stages were integrated in the focus. Furthermore, the interdependencies between the determining factors, the initiated approaches and company's subsystems were determined. The integrated complexity management provides a concept for an effective handling of complexity problems [90]. Therefore, it can be assumed that complexity drivers come more and more into scientific focus at the transition between variant management and complexity management in the early 1990s of the last century.

Another reason could be attributed to the definition and understanding of the term "complexity driver". In the literature, complexity drivers were defined in many ways (see Sect. 3.2). For the authors, complexity drivers have an influence on something and are responsible for increasing complexity in a system. In our research, we found out that the first definition about complexity drivers was specified by Schmidt [227] in the year 1992.

In variant management, the sources, which were responsible for increasing variant diversity and complexity, were called "variant driver" [240]. Thus, it is an indication for us that the term complexity driver can be attributed to the term variant driver.
Fig. 3 Complexity management's evolution [85]

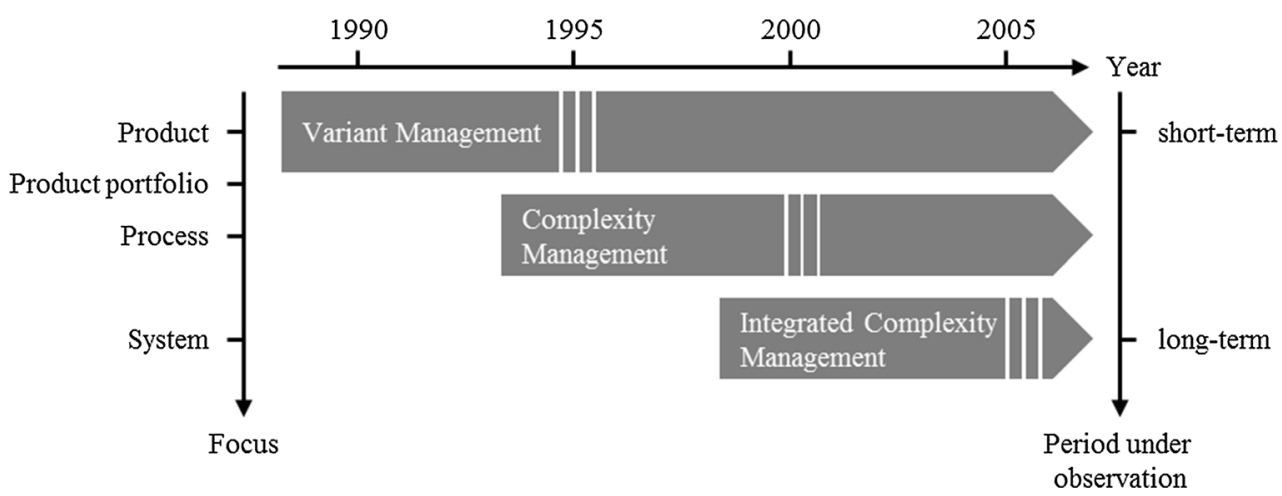




\section{Literature review about complexity drivers}

\subsection{Overview about literature research results}

Table 2 presents an overview about the identified literature sources and the number of publications in the field of complexity drivers in manufacturing companies and along the value chain (published between 1991 and 2015). More than $50 \%$ of the publications about complexity drivers were published in journals and $\mathrm{PhD}$ theses. Thus, complexity drivers have a high importance in scientific research. Complexity drivers are also mentioned in several books, essays, conference proceedings as well as working papers with a practical and/or scientific purpose. Working papers are publications from companies or universities with a practical and/or scientific purpose. In this research, most of the identified working papers are practically oriented. Newspapers and the Internet are also literature sources for complexity drivers. After analyzing the different literature sources and their focuses, we conclude that complexity drivers have a high relevance in practice as well as in scientific research.

As already mentioned, in our research we identified 235 papers about complexity drivers in the literature and clustered them according to their content in nineteen clusters (see Table 3). Building the nineteen clusters was an iterative process. We started by comparing the papers according to their content and generated the clusters based on their communalities and differences. One hundred and sixty papers $(68 \%)$ are only focused on complexity drivers (Cluster \#10), nineteen papers (8\%) are focused on complexity drivers and complexity driver's definition (Cluster $\# 12$ ), and twelve papers (5\%) are focused only on complexity drivers and approaches for complexity driver's identification (Cluster \#14). Furthermore, 169 papers $(72 \%)$ are written in German and $66(28 \%)$ in English.

In addition, we discovered that $212(90 \%)$ of the total amount of 235 papers describe specific complexity drivers in manufacturing companies and along the value chain (Cluster \#10-\#19). One hundred and fifty-four papers $(73 \%)$ are written in German and fifty-eight $(27 \%)$ in English. Twenty-three papers (Cluster \#1-\#9) comprise only general information about complexity drivers without the description of specific complexity drivers in manufacturing companies and along the value chain.

For separating the literature into the two parts "manufacturing companies" and "along the value chain", we analyzed the 212 literature sources and the identified complexity drivers regarding their focus. We followed the complexity driver's assignment to certain categories that the paper's authors used. If they describe complexity drivers, which belong to different parts of the value chain, we followed their assignment and used this information in our study. We assumed complexity drivers, which are not assigned to a certain part of the value chain by the authors, to be general in manufacturing companies. This separation is important for the management in a company, because higher management (e.g., CEO or director) needs a vast overview of the whole company and the occurring complexity drivers, whereas managers of certain departments (e.g., senior manager, department manager, team leader) need an overview about complexity drivers in their specific fields of interest.

Previous literature studies about complexity drivers have been done by four authors with different objectives: Meyer [174], Serdarasan [255, 256] and Wildemann and Voigt [289]. Principally, it can be distinguished between literature review and literature overview/survey. A literature overview/survey reviews the existing literature in a particular field of interest on a surface level. However, a literature review analyzes and evaluates the existing literature more in detail as an overview/survey and gives the reader a better understanding of the research [258]. Serdarasan [255, 256] signifies their literature studies as reviews and gives a detail overview of the "literature on supply chain complexity and its drivers". The literature studies of Meyer [174] and Wildemann and Voigt [289] refer to a literature research only on complexity drivers and can be assigned to the category literature overview/survey.

In his PhD thesis, Meyer [174] describes the state of the art regarding specific complexity drivers and their influence on increasing complexity. Before reviewing the literature, Meyer [174] describes his understanding of the term complexity drivers and states that complexity drivers are factors, which influence the system's complexity and are responsible for changing system's complexity level [174]. The literature results are subdivided by Meyer [174] into two categories:

Category \#1: General complexity drivers and their influences on increasing complexity in a company.

Category \#2: Major complexity drivers and their influences regarding logistics.

According to Meyer [174], the complexity drivers and their influences in category \#1 are based on variant management. They concern mostly product complexity and product complexity's area of influence. As a result of the literature research, Meyer [174] identifies nineteen literature sources and describes 127 complexity drivers in fourteen driver categories. In summary, Meyer [174] offers a table, showing the identified complexity drivers, their appearances in the literature and their influences. However, he does not describe a comparison between the different literature sources. Furthermore, he focused his research 


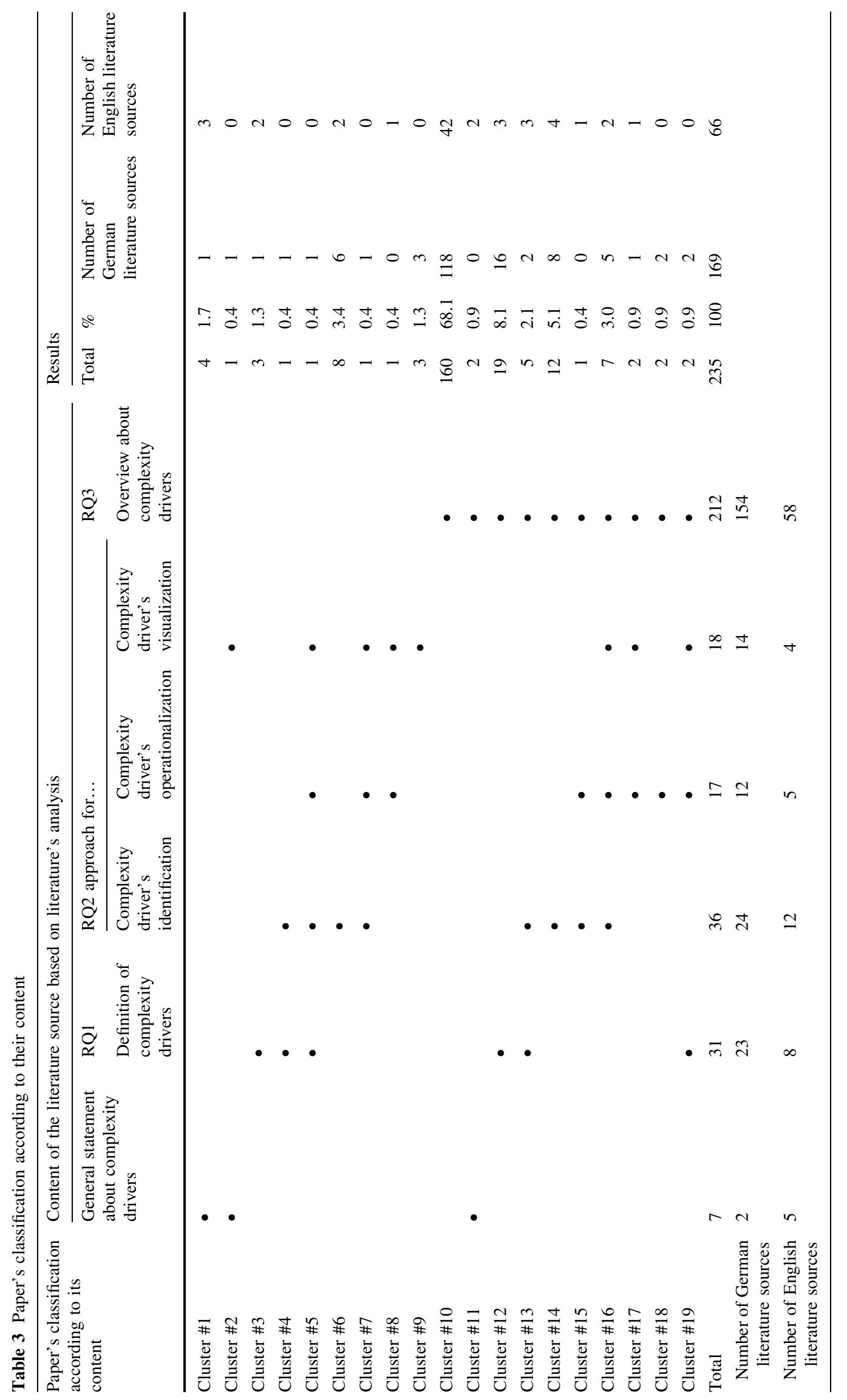


only on general complexity drivers and complexity drivers regarding logistics. Complexity drivers in other parts along the value chain are not described and compared with his findings. In addition, Meyer [174] does not describe specific approaches for complexity driver's identification, operationalization and visualization. No research questions, databases, search terms and synthesizing methods are determined.

Serdarasan [255, 256] published two review papers concerning supply chain complexity drivers. The first paper was published in the proceedings of the 41st International Conference on Computers \& Industrial Engineering in 2011. The second paper was published in the journal of Computers \& Industrial Engineering in 2013. In her papers, Serdarasan $[255,256]$ reviews the "typical complexity drivers that are faced in different types of supply chain and presents the complexity driver and solution strategy pairings in the form of a matrix". The information was extracted from real-life supply chain situations and gathered from multiple existing sources such as interviews, observations, reports and archives.

In the first paper, Serdarasan [255] reviews the literature on supply chain complexity drivers, because in her opinion, this is the first step in developing a clear strategy for complexity handling. Before reviewing the literature, Serdarasan [256] analyzed the three different types of supply chain complexity (static, dynamic and decision making) and describes her understanding of the term complexity drivers. In her understanding, "a supply chain complexity driver is any property of a supply chain that increases its complexity" and corresponds with the different types of supply chain complexity [255]. Furthermore, Serdarasan [255] classifies the complexity drivers "according to their origin in internal, supply/demand interface, and external/ environmental drivers". In total, twenty-three literature sources are identified and twenty-seven complexity drivers are described in the three driver categories internal, supply/ demand interface and external. In addition, Serdarasan [255] gives an overview of twenty-seven different solution strategies for handling specific complexity drivers. However, the information about all references and the systematic review results are not described, because of "space restrictions" in the conference paper [255].

In summary, in her first paper Serdarasan [255] offers an overview, showing the identified complexity drivers and their overall origin categories, and describes some solution strategies for complexity driver's handling. However, she does not describe a comparison between the different literature sources and their findings. Furthermore, she focused her research only on supply chain complexity drivers. Complexity drivers in other parts along the value chain are not described and compared with her findings.
In the second paper, Serdarasan [256] enhances the content of her first paper and reviews the "typical complexity drivers that are faced in different types of supply chains and present the complexity driver and solution strategy pairings based on good industry practices". Analogously to the first paper, Serdarasan [256] distinguishes in the first step the supply chain complexity in the already mentioned three types: static, dynamic and decision making. Then, she describes her understanding of the term complexity drivers and combines it with the different types of supply chain complexity and their origin (internal, supply/demand interface and external/environmental). In the next step, Serdarasan [256] analyzes the identified thirty-eight literature sources focused on supply chain complexity according to their type and origin. As a result of the analysis, Serdarasan [256] states that the related literature is mostly focused on internal and interface complexities. The number of studies dealing with external complexity drivers is smaller, because "external drivers are outside the system boundary of the supply chain". According to the three types of supply chain complexity, the literature is mostly focused on static and dynamic types. Decision-making complexity is also much less in the focus of the literature. Based on her literature research, Serdarasan [256] developes a classification of supply chain complexity drivers according to their type and origin. Thirty-two supply chain complexity drivers are described in nine complexity driver categories. For complexity drivers handling, Serdarasan [256] extends the overview of different solution strategies from twenty-seven in the first paper to thirty-three in the journal paper.

Summarizing the second paper, Serdarasan [256] presents a table, consisting of the identified complexity drivers, which were clustered according to their type and origin. Furthermore, she compares the different literature sources and their findings to identify communalities and differences. Analogously to the first paper, Serdarasan [256] focuses her research only on supply chain complexity drivers. Complexity drivers in other parts along the value chain are not described and compared with her findings.

In addition, Serdarasan $[255,256]$ does not describe specific approaches for complexity driver's identification, operationalization and visualization in her two papers. Beyond, no research questions, databases, search terms and synthesizing methods are determined.

The objective of Wildemann and Voigt's research [289] is to identify internal and external complexity drivers in manufacturing companies with the aim of quantifying company's product portfolio, process and structure complexity. As a result, a company's complexity profile can be compared across other companies. The basis of Wildemann and Voigt's [289] overview is a comprehensive literature and case study analysis about complexity drivers. 
Before starting the literature research, Wildemann and Voigt [289] analyzed the term complexity extensively to develop their own definitions for internal and external complexity. According to Wildemann and Voigt [289], external complexity is the sum of all parameters in a company that cannot be influenced or can only be indirectly influenced. External complexity is constitutive traits for a company's processes that product program and the company's structure exhibit. Their dynamics are only predictable to some extent. Internal complexity is the sum of all material and immaterial units in a company and their static and dynamic links that express the external requirements within the company borders.

For complexity driver's understanding, Wildemann and Voigt [289] cite the definition of Piller that complexity drivers are a "phenomenon, which actuate a system to increase their own complexity".

Based on this understanding, Wildemann and Voigt [289] perform a comprehensive literature research focused on complexity drivers and separate the identified complexity drivers according to their origin into internal and external categories. As a result of their literature research, Wildemann and Voigt [289] identify seventeen literature sources about complexity drivers and identify thirty-two external and sixty-three internal complexity drivers, which are allocated in eleven driver categories. Wildemann and Voigt [289] criticize that literature's assignment of complexity drivers to different driver clusters show some contradictions. In addition to their literature research, Wildemann and Voigt [289] analyze twenty-seven case studies to extend literature's results about complexity drivers with complexity drivers identified in practice. The case studies comprise different branches to provide a differentiated overview about external drivers and their internal impacts. In summary, 115 different complexity drivers are identified and clustered according to nine main driver categories (three external and six internal). Then, the results are visualized in a "complexity driver tree" and evaluated in a further empirical study to identify the most relevant complexity drivers for practice. As a result, the total amount of complexity drivers is condensed to an amount of complexity drivers, which are easy to handle in practice. Based on expert interviews, Wildemann and Voigt [289] finally identify ten relevant external and twenty relevant internal complexity drivers. The concentrated complexity drivers are the basis for an additional empirical research by online questioning. Within the questioning, the trends of internal and external complexity drivers, their relevance and influences on company's processes are investigated. The results from literature and empirical research are the inputs for the development of a complexity index [289].
In summary, Wildemann and Voigt [289] present in the first step a literature overview about complexity drivers general in manufacturing companies. The identified drivers are clustered according to origin in internal and external drivers. The authors compare the different literature sources and their findings to identify communalities and differences. Then, they compare the literature results with the results from empirical research to extend the total amount of complexity drivers. The results are visualized in a complexity tree. The practical relevant drivers are identified through expert interviews. However, Wildemann and Voigt [289] focus their research only on general complexity drivers. Complexity drivers in other parts of the company and along the value chain are not described and compared with their findings. In addition, Wildemann and Voigt [289] do not describe specific approaches for complexity driver's identification and operationalization. Only one method for complexity driver's visualization is described. For literature research, no research questions, databases, search terms and synthesizing methods are determined.

Table 4 summarizes the results of our analysis according to the previous literature studies about complexity drivers. The table shows a list of existing reviews and overviews/surveys and gives an overview of their focus, research period and results about complexity drivers. Furthermore, the identified literature studies are analyzed and evaluated based on the requirements of a systematic, explicit and reproducible literature review, described by Fink [78].

The evaluation is based on the following two criteria: fulfilled $(++)$ and not fulfilled $(-)$. Table 4 gives an overview about the determination of the two evaluation criteria in the following two categories:

- Determination of research questions, databases, search terms and synthesizing methods.

- Comparison of literature findings with other literature sources or empirical research data.

As a result of Table 4 and the analysis of the previous literature studies, the existing studies cover complexity drivers on specific issues such as logistics, supply chains or general in manufacturing companies (see Table 4).

A vast number of literature sources and complexity drivers in the referred field are covered in these literature studies, although a systematic, explicit and reproducible method for identification, evaluation and synthesizing the existing literature about complexity drivers is not described [78]. In the previous literature studies, no research questions, databases, search terms and synthesizing methods are described (see Table 4). Furthermore, the literature findings are only compared in two of the four studies to identify communalities and differences to improve reader's 
Table 4 List of existing reviews or overview about complexity drivers and their results

\begin{tabular}{|c|c|c|c|c|}
\hline Author(s) & Meyer [174] & Serdarasan [255] & Wildemann and Voigt [289] & Serdarasan [256] \\
\hline Type of literature study & Overview & Review & Overview & Review \\
\hline Publication's language & German & English & German & English \\
\hline \multicolumn{5}{|l|}{ Focus } \\
\hline General in manufacturing companies & $\bullet$ & & $\bullet$ & \\
\hline \multicolumn{5}{|l|}{ Product development } \\
\hline \multicolumn{5}{|l|}{ Procurement/purchasing } \\
\hline Logistics & $\bullet$ & & & \\
\hline \multicolumn{5}{|l|}{ Production } \\
\hline \multicolumn{5}{|l|}{ Order processing/distribution/sale } \\
\hline Internal supply chain & & $\bullet$ & & $\bullet$ \\
\hline \multicolumn{5}{|l|}{ Remanufacturing } \\
\hline \multicolumn{5}{|l|}{ General in value chain } \\
\hline Research period & 1992-2004 & $1998-2011$ & $1991-2010$ & 1992-2011 \\
\hline \multicolumn{5}{|l|}{ Literature review's results: amount of... } \\
\hline Identified literature sources & 19 & 25 & 17 & 38 \\
\hline Complexity driver's definitions & 1 & 1 & 1 & 1 \\
\hline Described complexity drivers & 127 & 27 & 95 & 32 \\
\hline Complexity driver categories & 14 & 3 & 11 & 9 \\
\hline \multicolumn{5}{|l|}{ Determination of $\ldots$ by the author(s) } \\
\hline Research questions & - & - & - & - \\
\hline Databases & - & - & - & - \\
\hline Search terms & - & - & - & - \\
\hline Synthesizing methods & - & - & - & - \\
\hline \multicolumn{5}{|l|}{ Literature findings' comparison with... } \\
\hline Other literature sources & - & - & ++ & ++ \\
\hline Empirical research data & - & - & ++ & - \\
\hline
\end{tabular}

Evaluation criteria: fulfilled $(++)$, precise research questions, databases, search terms and synthesizing methods, are described. The literature findings are compared with other literature sources or empirical research data; not fulfilled (-), precise research questions, databases, search terms and synthesizing methods are not described. The literature findings are not compared with other literature sources or empirical research data

understanding in a particular field of research. These are essential to determine the current state of knowledge about a particular research issue in a literature review according to Fink [78].

The existing literature studies only describe complexity drivers in a specific field of manufacturing companies. A more general overview about complexity drivers in manufacturing companies and along the value chain does not exist yet. Furthermore, no different definitions of complexity drivers are identified, compared and discussed in the previous literature studies. Meyer [174], Serdarasan $[255,256]$ and Wildemann and Voigt [289] provide only one definition for complexity drivers. In our opinion, a more extensive point of view is necessary to identify all characteristics of complexity drivers. Complexity driver's understanding is the first step in managing complexity (see Sect. 3.1).
In the existing studies, no approaches for complexity driver's identification or operationalization are described. A specific and target-oriented complexity management is based on identification, operationalization and visualization of a system's complexity drivers (see Sect. 3.2). For science and practice, it is important to know that different methods for complexity driver's identification, operationalization and visualization exist in the literature. Only Wildemann and Voigt [289] describe a method for complexity driver's visualization in their research paper. However, this method is not applicable in all cases; thus, further methods for complexity driver's visualization are required.

In our research paper, we want to close the referred gaps by a systematic, explicit and reproducible literature review about complexity drivers general in manufacturing companies and along the value chain. 


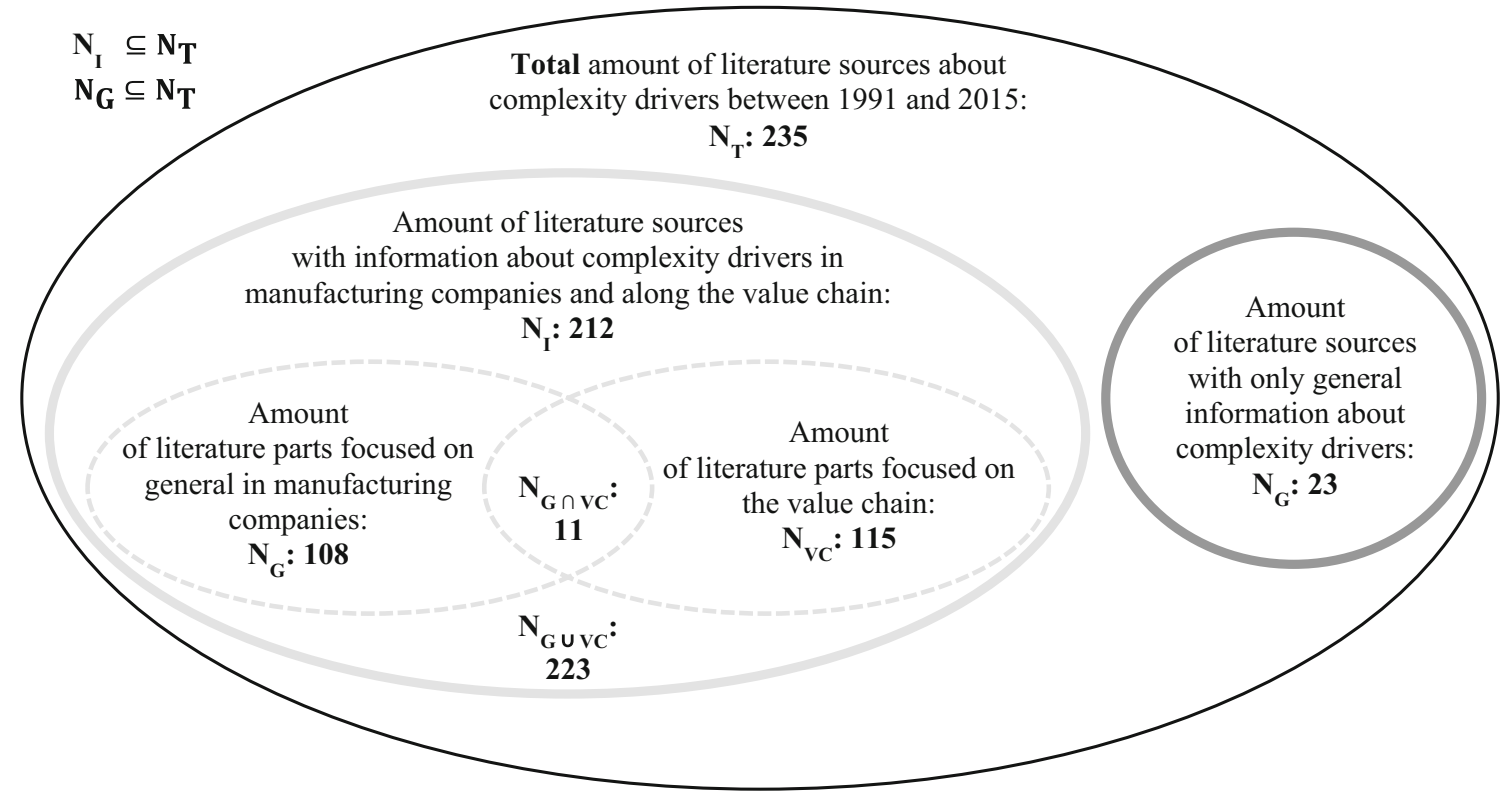

Fig. 4 Overview about literature analysis' results

According to the literature, the existing studies are only focused on specific issues such as logistics, supply chain or general in the company (see Table 4). One of this paper's purposes is to present an overview about complexity drivers in all aspects along the value chain and in manufacturing companies in attempt to close this literature gap. Furthermore, the results are compared with each other to identify communalities and differences between complexity drivers general in manufacturing companies and along the value chain. In addition, we identify and analyze all existing definitions of complexity drivers and develop a new overall definition to increase the understanding of complexity drivers. Our objective is to fulfill all requirements of a literature review in general.

To achieve this aim, the identified 235 literature sources $\left(\mathbf{N}_{\mathbf{T}}\right)$ were analyzed in detail (Fig. 4). Twenty-three papers are focused only on general information about complexity drivers. As already mentioned, 212 papers $\left(\mathbf{N}_{\mathbf{I}}\right)$ contain information about complexity drivers in manufacturing companies and along the value chain. Within these 212 papers, 108 literature parts $\left(\mathbf{N}_{\mathbf{G}}\right)$ can be identified that deal with complexity divers general in manufacturing companies. Furthermore, 115 literature parts $\left(\mathbf{N}_{\mathbf{V C}}\right)$ are focused on complexity drivers along the value chain. Eleven papers describe both parts $\left(\mathbf{N}_{\mathbf{G}} \cap \mathbf{N}_{\mathbf{V C}}\right)$.

After identification and segmentation of the researched literature, the next step was to analyze the overall trend of all literature regarding complexity drivers in manufacturing companies and along the value chain (Fig. 5). Further, the results were separated in German and English publications.
Figure 5 presents the total amount of publications regarding complexity drivers published in the time period 1991-2015.

The represented trend shows an increased interest in complexity drivers throughout the last 10 years, because they are the basement of a target-oriented complexity management. It can be derived that complexity drivers attract more and more focus in scientific research. Another reason for the increase numbers of literature sources might be the increased amount of included literature sources in databases over time. For example, the database EBSCOhost enhanced their connection to other databases over the last years, and thus, it covers more and more books, journals and conference papers. Seventy-four percent of all publications were published between 2004 and 2015. Furthermore, 72\% of all publications were published in German. However, the amount of English publications increased continuously in the last 6 years.

As already mentioned, 212 papers (90\% of all literature sources) describe specific complexity drivers in manufacturing companies and along the value chain. After analyzing and synthesizing these 212 papers, we identified 223 different literature parts with complexity drivers in manufacturing companies and along the value chain (see Fig. 4 and Table 14 in "Appendix"). Thus, eleven authors have described more than one field of complexity drivers in their publications (see Fig. 4). For example, Mayer [170], Meyer [174] and Lasch and Gießmann [155] describe in their publications complexity drivers general in manufacturing companies and drivers in the field logistics. 
Fig. 5 Trend of all literature sources about complexity drivers between 1991 and 2015
Fig. 6 Trend of the literature about general complexity drivers in manufacturing companies and complexity drivers along the value chain in manufacturing companies between 1991 and 2015
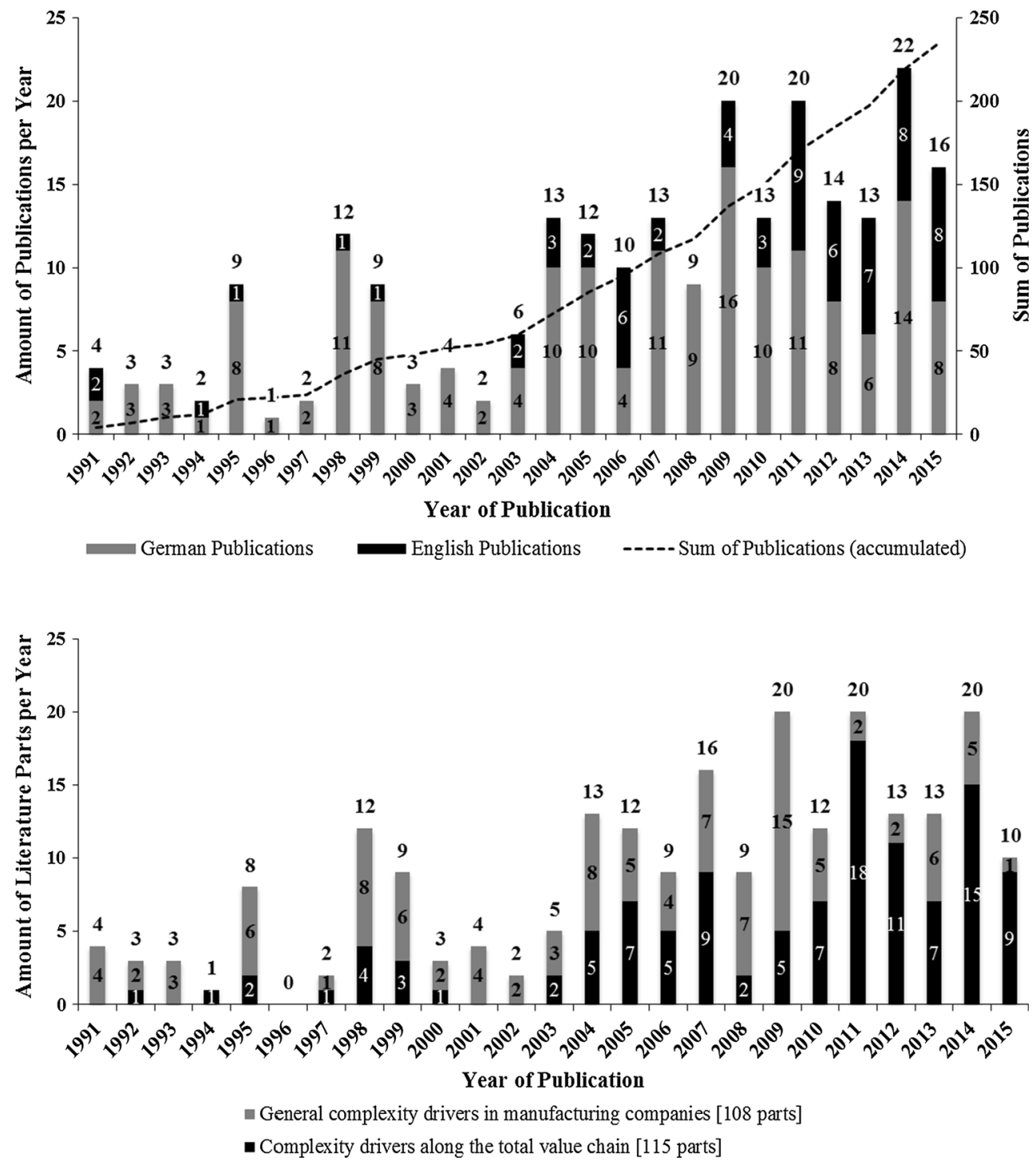

With regard to the existing literature, the data from Fig. 5 were separated in two categories to allow the researchers an overview about the different trends in the literature regarding complexity drivers (Fig. 6) and their increasing importance for manufacturing companies:

- General complexity drivers in manufacturing companies (108 parts).

- Complexity drivers along the value chain (115 parts).

Furthermore, the different trends in the literature show the current research direction and give an implication for gaps and future research.

Figure 6 shows these referred trends during the last 25 years. One hundred and eight literature parts (48\%) concern general complexity drivers in manufacturing companies. Most of these publications were published between the years 1998 and 2010 (70\%). On the other side, one hundred and fifteen publications describe complexity drivers along the value chain. Eighty-three percent of the publications about complexity drivers along the value chain were published in the last 10 years. Thus, there is an increasing interest in complexity drivers along the value chain in scientific literature.

Comparing the focus of publications in the early years with the focus of publications during more recent years shows that complexity drivers are now described more in detail regarding different parts along the value chain. This indicates that complexity drivers gain more and more importance in scientific research.

According to Wildemann [288], Schönsleben [234], Blecker and Kersten [20] and Kaluza, Bliem and Winkler [126], we separated the value chain in seven different fields: product development (PD), procurement/purchasing $(P C)$, logistics $(L)$, production $(P R)$, order processing/ 
distribution/sale (OPD), internal supply chain (SC) and remanufacturing $(R)$.

Furthermore, we extend this separation by introducing the field general in value chain $(V C)$, because in our research we found out that some authors described complexity drivers along the value chain in general.

To allow an overview about the trend of the literature in the eight different fields of the value chain, the data from Fig. 5 in the category complexity drivers along the value chain were separated. Table 5 gives an overview about the amount of literature across the last 25 years in particular fields of the value chain. The table also shows that the amount of publications about complexity drivers in all eight different fields has increased. Thus, there is an increasing interest in complexity drivers in the last 10 years.

The main focus is on internal supply chain (23\%), production $(22 \%)$, logistics $(16 \%)$, product development (15\%) and order processing/distribution (11\%). Eightyseven percent of all publications are focused on these fields. This shows that these fields are identified by several researches as important sources of complexity in the company and were analyzed precisely within the last 25 years. Other important sources of complexity are the fields procurement, remanufacturing and general in value chain, but only $13 \%$ of the publications are focused on these fields. With a percentage of $3.5 \%$, the field remanufacturing has the smallest proportion of all publications. The analysis shows that in the fields procurement, remanufacturing and general in value chain future research is necessary, because these fields are also important sources of complexity in manufacturing companies. Based on the systems theory, complexity occurs not only in specific parts of a system. Instead, handling complexity requires a consideration of all parts and their interdependencies in a system.

\subsection{Definition of complexity drivers}

Complexity management in the company requires identification and controlling of the essential complexity drivers [44, 240], because "complexity drivers can yield in increasing complexity" [19]. Before identification, it is necessary to understand what a complexity driver is [144, 174]. Lucae, Rebentisch and Oelmen [162] argue that it is important "to better understand the complexity drivers that are impeding reliable planning and common planning mistakes made in large-scale engineering programs". In the literature today, there is no universal understanding of the term "complexity driver" [174]. Buob [46] argues that the term "complexity driver" cannot be defined extensively.

Answering the first research question, we analyzed the identified literature. Several different definitions exist in the literature, but they all tend to the same content and seem alike and not different (Table 6).

To describe the term complexity driver, the first step is to understand what a driver is in general. In the Business Dictionary [47], three different definitions of the term "driver" exist:

1. Condition or decision that causes subsequent conditions or decisions to occur as a consequence of its own occurrence.

2. Element of a system that has a major or critical effect on the associated elements or the entire system.

3. Root cause of a condition or measurement.

These three different definitions show that a driver is responsible for a situation or condition and has an impact on it. Table 6 presents several definitions about complexity drivers that exist in the literature and their authors. In total, thirty-six literature sources describe different definitions about complexity drivers. Twenty-six sources are written in German and ten in English. Generally, the definitions can be separated in five main categories: factors, indicators, sources, parameters/variables and symptoms/phenomenon, which influence a system's complexity. The different complexity driver's categories are filled with information from German- and English-written studies. Most of the different driver's categories comprise information from both languages. Only the category "sources" are described only in German-written literature studies. Further, it can be seen that the English literature sources are concentrated on the categories "factors" and "indicators". For literature's synthesizing, we analyzed the different statements or definitions of the authors and summarized them in a superior statement, which is described in Table 6.

After analyzing and synthesizing the existing literature and the described different definitions of complexity drivers, we come to the conclusion that an overall definition is required to summarize all collected information in one definition.

For the development of the new definition, we proceeded in the following way: In the first step, we analyzed the characteristic of a definition itself. The first common statement of a definition is by Aristoteles. He states that a definition is a "statement, which contains the essence of the object that is to be defined" [66]. The Encyclopedia of Language and Linguistics describes a definition as a "statement of the meaning of a word, term, or symbol" [42]. The encyclopedias of BROCKHAUS [35] and DIE ZEIT [63] extend the mentioned definition and describe a definition as a "determination of a term by specifying the essential attributes" [35, 63]. According to the Encyclopedia of Language and Linguistics, a "traditional definition consists of a genus term and any of a number of differentia. The genus term answers the question, 'What 


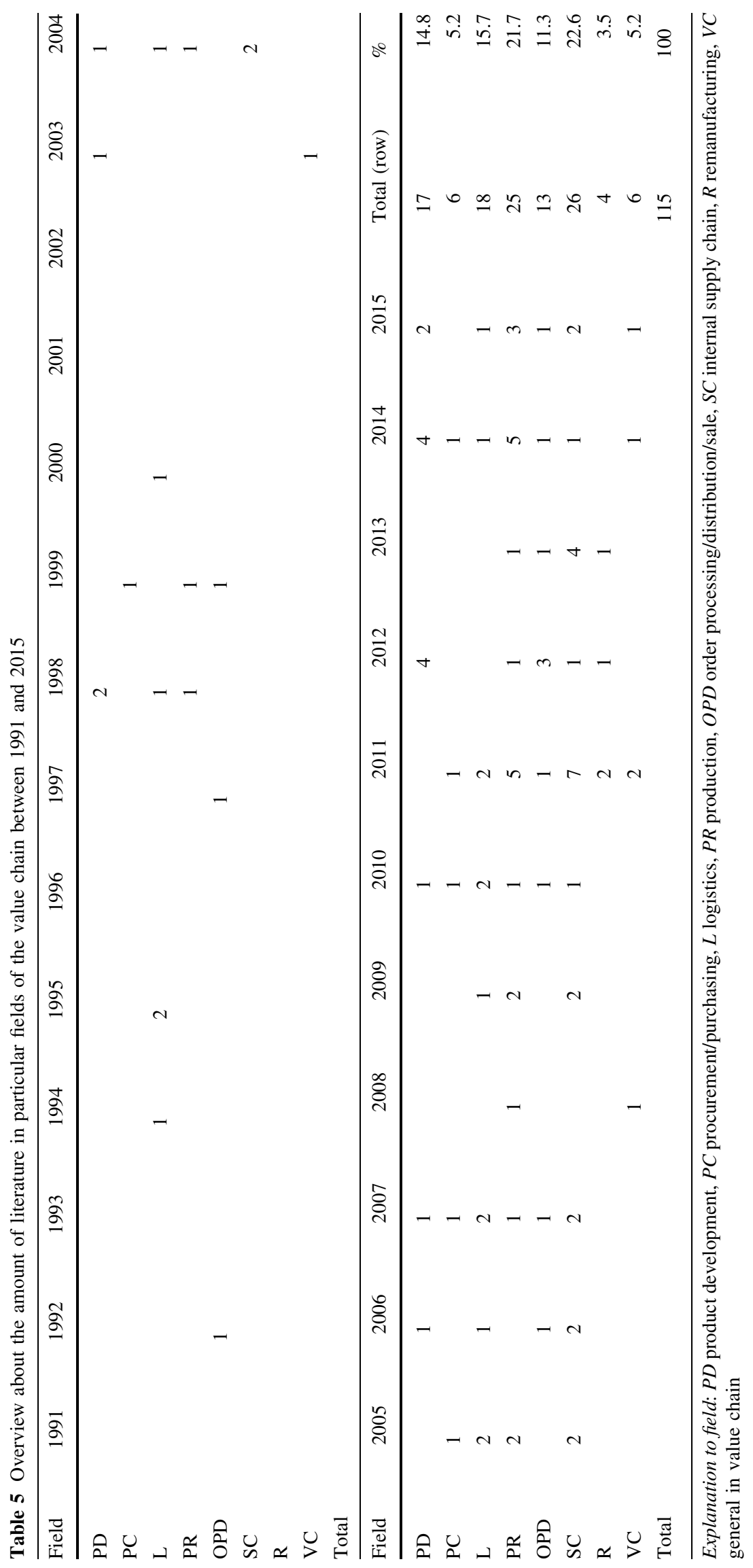


Table 6 Definitions of complexity drivers in scientific literature

\begin{tabular}{|c|c|c|}
\hline $\begin{array}{l}\text { Complexity driver's } \\
\text { category }\end{array}$ & Author(s) & Definition The author( $(s)$ describe( $s)$ complexity drivers as... \\
\hline \multirow[t]{5}{*}{ Factors } & $\begin{array}{l}\text { Schmidt }[227]^{1} \text {; Reiß }[213]^{1} \text {; Fleck }[79]^{1} \text {; Höge }[118]^{1} \text {; } \\
\text { Bohne }[26]^{1} \text {; Puhl }[204]^{1} \text {; Berens and Schmitting }[14]^{1} \text {; } \\
\text { Fehling }[76]^{1} \text {; Giannopoulos }[87]^{2} ; \text { Buob }[46]^{1}\end{array}$ & ...factors, which influence a system's complexity \\
\hline & Piller and Waringer [202] ${ }^{1}$ & ...factors, which increase a system's complexity \\
\hline & Hanenkamp $[107]^{1} ;$ Meyer $[174]^{1} ;$ Lammers $[154]^{1}$ & $\begin{array}{l}\text {..factors, which influence the system's complexity and are } \\
\text { responsible for changing system's complexity level }\end{array}$ \\
\hline & Schuh, Gartzen and Wagner $[244]^{2}$ & ...factors, which may create high complexity \\
\hline & Christ $[52]^{1}$ & $\begin{array}{l}\text {..factors, which are responsible for resource wasting } \\
\text { ('Muda') in the company }\end{array}$ \\
\hline \multirow[t]{3}{*}{ Indicators } & $\begin{array}{l}\text { Warnecke and Puhl }[276]^{1} \text {; Puhl }[204]^{1} \text {; Perona and } \\
\text { Miragliotta }[198]^{2} \text {; Giannopoulos }[87]^{2} \text {; Leeuw, } \\
\text { Grotenhuis and Goor }[158]^{2}\end{array}$ & ...indicators, which influence a system's complexity \\
\hline & Payne and Payne $[196]^{2}$ & $\begin{array}{l}\text {...indicators for complexity, but they do not describe all } \\
\text { characteristics of the phenomenon }\end{array}$ \\
\hline & Rudzio, Apitz and Denkena [217] ${ }^{1}$ & ...indicators, which indicate high complexity in the company \\
\hline \multirow[t]{2}{*}{ Sources } & Wildemann $[284]^{1}$ & ...sources, which are responsible for a system's complexity \\
\hline & Gießmann and Lasch $[89]^{1}$ & $\begin{array}{l}\text {...sources, which influence the target achievement in the } \\
\text { company }\end{array}$ \\
\hline \multirow[t]{3}{*}{ Parameters/variables } & Biersack $[17]^{1}$ & $\begin{array}{l}\text {...parameters, indicators or factors, which help to define the } \\
\text { characteristics and economic effects of a system's } \\
\text { complexity }\end{array}$ \\
\hline & Schließmann $[224]^{1}$; Gerschberger et al. $[86]^{2}$ & $\begin{array}{l}\text {..parameters, which are responsible for a system's } \\
\text { complexity }\end{array}$ \\
\hline & Schwenk-Willi [252] ${ }^{1}$ & $\begin{array}{l}\text {..variables, which depend on one another, without complete } \\
\text { reduction to another one }\end{array}$ \\
\hline \multirow{2}{*}{$\begin{array}{l}\text { Symptoms/ } \\
\text { phenomenon }\end{array}$} & Höge [118] ${ }^{1}$ & ...symptoms of a system's complexity \\
\hline & Dehnen [59] ${ }^{1}$; Götzfried [94] ${ }^{2}$ & $\begin{array}{l}\text {..phenomenon, which actuate a system to increase own } \\
\text { complexity }\end{array}$ \\
\hline \multirow[t]{3}{*}{ Others } & Dehnen $[59]^{1}$ & ...dimensions of complexity \\
\hline & $\operatorname{Moos}[178]^{1}$ & $\begin{array}{l}\text {..forces, which encourage a system's complexity and are } \\
\text { located on the interface between external and internal } \\
\text { complexity }\end{array}$ \\
\hline & Serdarasan $[255,256]^{2}$ & ...properties, which increase a system's complexity \\
\hline
\end{tabular}

Language of literature source: ${ }^{1}$ German (number: 26 ); ${ }^{2}$ English (number: 10)

sort of thing is it?'. The differentia distinguish it from members of related sets" [42]. The encyclopedias of DIE ZEIT [63] describe the genus term as the "generic term (genus proximum)". The differentia specifies the differences in nature [63].

Based on definition's structure in the literature, in the next step, we analyzed the existing definitions and statements according to their structure. In all definitions or statements, the term "complexity driver" is the genus term. The terms "factor" or "indicator" or "source" or "parameter" etc. are the hypernym of a class. The differentia describes the characteristic and the essential attributes of the definition and "distinguish it from members of related sets" [42]. The statements "[...] which influence a system's complexity" or "[...] which indicate high complexity in company" etc. are the identified differentia in our research.
In the literature, several hypernyms for complexity drivers are presented: factor, indicator, source, parameter, variable, symptom, phenomenon, dimension, force and property. However, the meanings of these terms are different (see Table 7). Thus, we analyzed these terms and compared the meanings with the general understanding of a complexity driver, described in the literature. According to Schuh [240], Meyer [174] and Krizianits [150], complexity drivers are causing something or have an effect or influence on something. Then, we evaluated the existing meanings based on the following three evaluation criteria

Fulfilled Content covers the general understanding $(++) \quad$ of a complexity driver in total and contains the two terms cause and influence 
Table 7 Definitions of complexity driver's hypernyms

\begin{tabular}{|c|c|c|}
\hline Complexity driver's hypernyms & Definition according to the Oxford Learner's Dictionary & Evaluation result \\
\hline Factor $[184]$ & "One of several things that cause or influence something" & ++ \\
\hline Indicator $[186]$ & "A sign that shows you what something is like or how a situation is changing" & - \\
\hline Source $[190]$ & "A person or thing that causes something, especially a problem" & + \\
\hline Parameter [187] & "Something that decides or limits the way in which something can be done" & - \\
\hline Variable [192] & "Able to be changed" & - \\
\hline Symptom [191] & "A sign that something exists, especially something bad" & - \\
\hline Phenomenon [188] & "A fact or an event in nature or society, especially one that is not fully understood" & - \\
\hline Dimension [183] & "The size and extent of a situation" & - \\
\hline Force $[185]$ & "The strong effect or influence of something" & + \\
\hline Property [189] & "A quality or characteristic that something has" & - \\
\hline
\end{tabular}

Explanation for evaluation criteria: ++ , fulfilled; + , partial fulfilled;,- not fulfilled

Partial Content covers the general understanding fulfilled (+) of a complexity driver partial and contains one of the two terms cause and influence

Not fulfilled Content covers not the general (-) understanding of a complexity. The two terms cause and influence are not described

The terms, which fulfill the general understanding of a complexity driver, are marked (see Table 7). The Oxford Learner's Dictionary defines the different hypernyms presented in Table 7. As a result, only the term factor consists the attributes cause and influence. Thus, we come to the conclusion that the term factor is the suitable hypernym for complexity drivers.

In the next step, we analyzed the identified differentia and compared them with each other to identify differences and communalities. Then, we clustered the differentia according to their content. In the literature, sixteen different differentiae are described. Some differentiae are used more often than others to describe complexity drivers. Table 8 presents the sixteen differentiae, their literature's occurrence and the results of differentia's clustering.

In summary, the sixteen differentiae can be clustered in five groups. The first group describes that complexity drivers have principally an influence on system's complexity. Group \#2 concretizes the statement of group \#1 and concludes that complexity drivers have not only an influence on system's complexity, but they are responsible for increasing the complexity level in a system. Group \#3 describes further that complexity drivers have a direct influence on company's target achievement. Beyond, complexity drivers are influenced by one another, that is by internal or external drivers, and cannot be reduced completely to another one (see Group \#4). Furthermore, complexity drivers help to define the characteristics or the phenomenon of a system's complexity (see Group \#5).
Based on the five differentia groups and the identified hypernym term "factor", we developed the following general complexity driver definition:

Complexity drivers are factors, which influence a system's complexity and company's target achievement. They are responsible for increasing system's complexity level and help to define the characteristics or the phenomenon of a system's complexity. Complexity drivers are influenced by one another, that is by internal or external drivers, and cannot be reduced completely to another one.

\subsection{Approaches for identification, operationalization and visualization of complexity drivers}

Complexity drivers have influence on companies and the total value chain [240]. A specific and target-oriented complexity management is based on identification, operationalization and visualization of a system's complexity drivers. Keuper [132] describes that handling a company's complexity depends on the complexity drivers. Schmitt, Vorspel-Rüter and Wienholdt [230] explain that the identification and classification of measureable complexity drivers are the baseline for complexity reduction. Further Schwenk-Willi [252] and Sun and Rose [266] argue that complexity drivers are necessary for operationalization and quantification of complexity. Greitemeyer, Meier and Ulrich [96] describe that complexity drivers are responsible for complexity costs. Moreover, they are necessary for the creation of complexity key performance indicators. Therefore, it is required to identify and evaluate the relevant drivers [96].

According to the quote "If you can't measure it you can't manage it". [102], it is important to quantify complexity drivers and their effects [109, 252, 264] from a 
Table 8 Overview of complexity driver's differentia and their literature's occurrence

\begin{tabular}{|c|c|c|c|}
\hline Type & $\begin{array}{l}\text { In the literature described complexity driver's } \\
\text { differentia }\end{array}$ & $\begin{array}{l}\text { Number of authors that } \\
\text { use this differentia }\end{array}$ & Clustering of the identified complexity driver's differentia \\
\hline$\# 1$ & {$[\ldots]$, which influence a system's complexity } & 18 & {$[\ldots]$, which influence a system's complexity } \\
\hline \#2 & $\begin{array}{l}{[\ldots], \text { which are responsible for a system's }} \\
\text { complexity }\end{array}$ & 3 & \\
\hline \#3 & [...], which encourage a system's complexity & 1 & \\
\hline \#4 & {$[\ldots]$, symptoms of a system's complexity } & 1 & \\
\hline \#5 & {$[\ldots]$, dimension of complexity } & 1 & \\
\hline \#6 & $\begin{array}{l}{[\ldots], \text { are responsible for changing system's }} \\
\text { complexity level }\end{array}$ & 3 & $\begin{array}{l}{[\ldots], \text { which are responsible for increasing system's }} \\
\text { complexity level }\end{array}$ \\
\hline \#7 & {$[\ldots]$, which increase a system's complexity } & 3 & \\
\hline \#8 & {$[\ldots]$, which may create high complexity } & 1 & \\
\hline \#9 & $\begin{array}{l}{[\ldots], \text { which indicate high complexity in the }} \\
\text { company }\end{array}$ & 1 & \\
\hline \#10 & $\begin{array}{l}{[\ldots], \text { which actuate a system to increase own }} \\
\text { complexity }\end{array}$ & 2 & \\
\hline \#11 & $\begin{array}{l}{[\ldots], \text { which are responsible for resource wasting }} \\
\text { in the company }\end{array}$ & 1 & {$[\ldots]$, which influence company's target achievement } \\
\hline \#12 & $\begin{array}{l}{[\ldots], \text { which influence the target achievement in }} \\
\text { the company }\end{array}$ & 1 & \\
\hline$\# 13$ & $\begin{array}{l}{[\ldots], \text { which depend on one another, without }} \\
\text { complete reduction to another one }\end{array}$ & 1 & $\begin{array}{l}{[\ldots], \text { are influenced by one another (internal or external) }} \\
\text { and cannot be reduced completely to another one }\end{array}$ \\
\hline \#14 & $\begin{array}{l}{[\ldots], \text { located on the interface between external }} \\
\text { and internal complexity }\end{array}$ & 1 & \\
\hline \#15 & $\begin{array}{l}{[\ldots] \text {, but they do not describe all characteristics of }} \\
\text { the phenomenon }\end{array}$ & 1 & $\begin{array}{l}{[\ldots] \text {, help to define the characteristics or the phenomenon }} \\
\text { of a system's complexity }\end{array}$ \\
\hline \#16 & $\begin{array}{l}{[\ldots], \text { which help to define the characteristic and }} \\
\text { economic effects of a system's complexity }\end{array}$ & 1 & \\
\hline
\end{tabular}

holistic view [266]. For quantifying complexity drivers and their effects, it is necessary to identify theoretically possible complexity drivers first. The next step is to identify practically relevant complexity drivers [109, 264], for example within an empirical research [289].

To answer the second research question, we analyzed the identified literature sources according to general approaches for complexity driver's identification, operationalization and visualization. Parry, Purchase and Mills [194] argue that recognition and identification of the complexity drivers "enable managers to realize value" and "reducing complexity where possible". Ehrenmann [67] argues further that complexity driver's analysis enables first indications about the success of process's changing.

\subsubsection{Identification of complexity drivers}

As a result of literature analysis, thirty-seven authors describe in their papers twenty-one different approaches for complexity driver's identification. Most of the identified approaches are published in German-written studies $(68 \%)$. More than $50 \%$ of the approaches are applied for complexity driver's identification general in manufacturing companies. Based on the literature analysis, the most applied approaches are expert interviews, process analysis and system analysis. Table 9 presents an overview of the identified approaches found in the literature and the fields on which they are focused. Some authors combine different approaches to identify complexity drivers. Furthermore, the identified approaches are clustered into seven fields, based on their principle to increase transparency. An evaluation of the different approaches regarding their practical uses wasn't conducted. This is a mere reflection of the approaches found in the literature. Such an evaluation can be an implication for further research.

According to Table 9, fourteen different authors use approaches based on questioning for identification and classification of complexity drivers. These approaches are applied to gather the expert's knowledge and experience. Further methods for identification of complexity drivers are the process or situation observation, the process analysis and the activity-based costing. They are used by eleven different authors. During a process analysis, the process is divided into its parts to increase process's understanding and to 


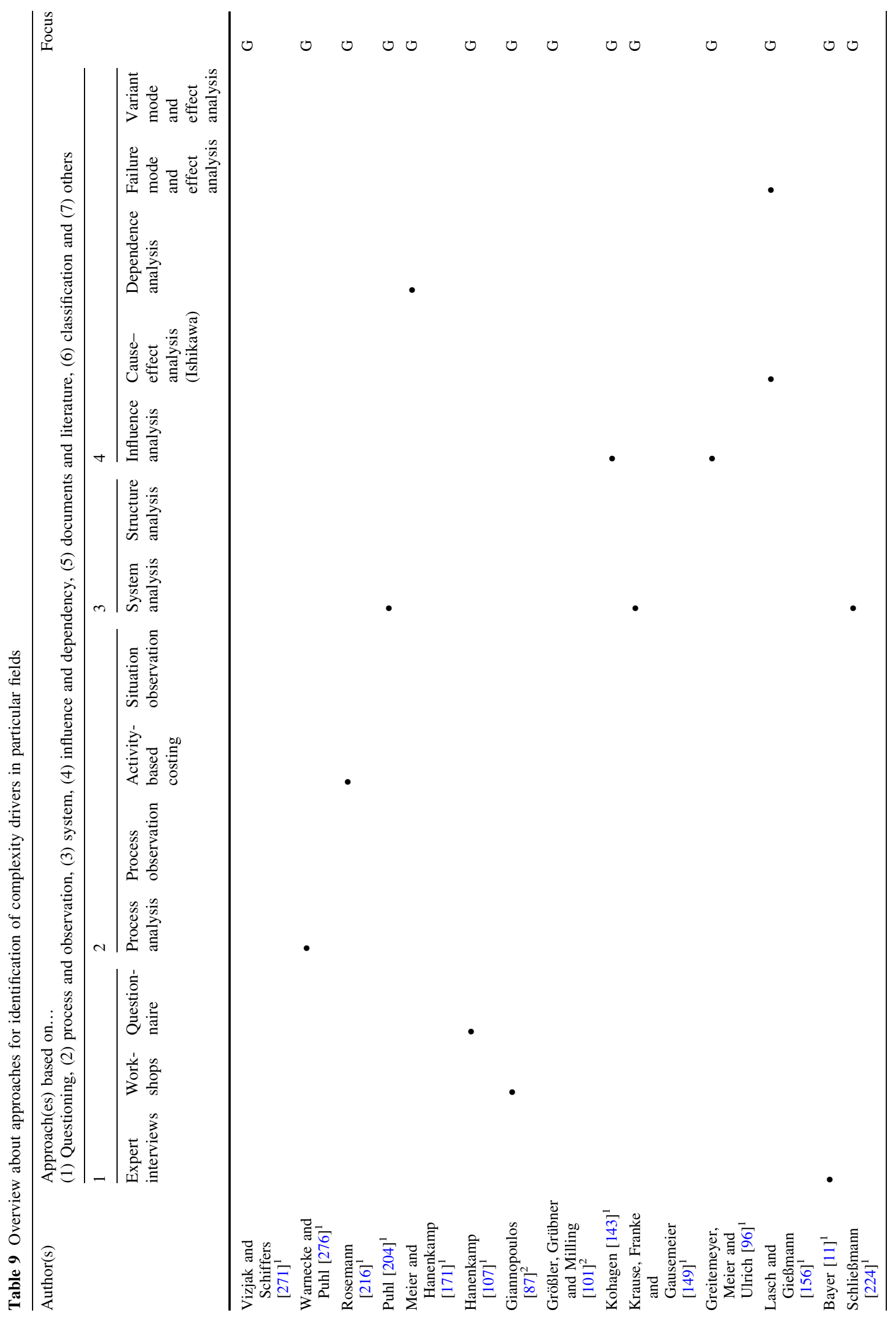




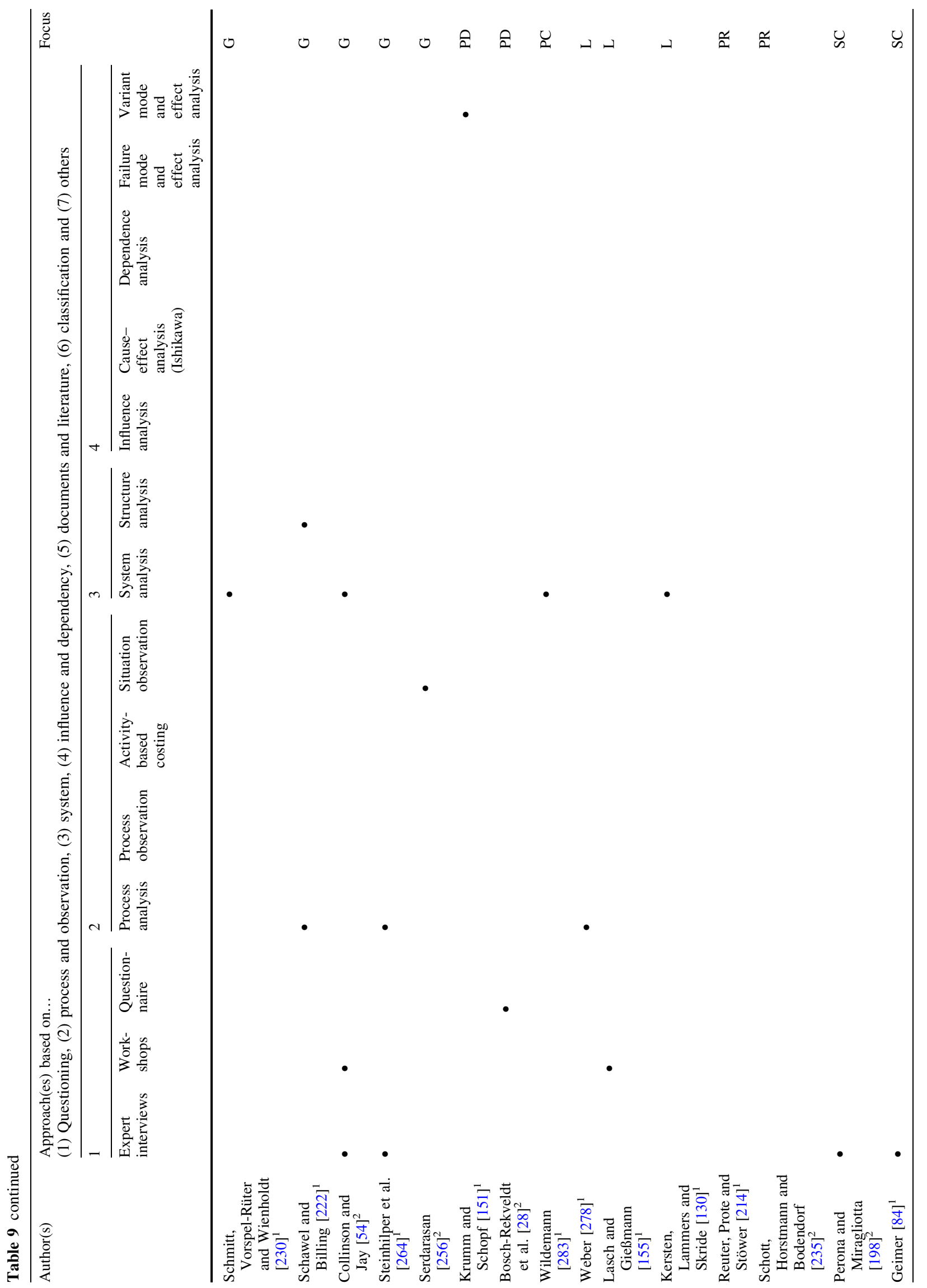




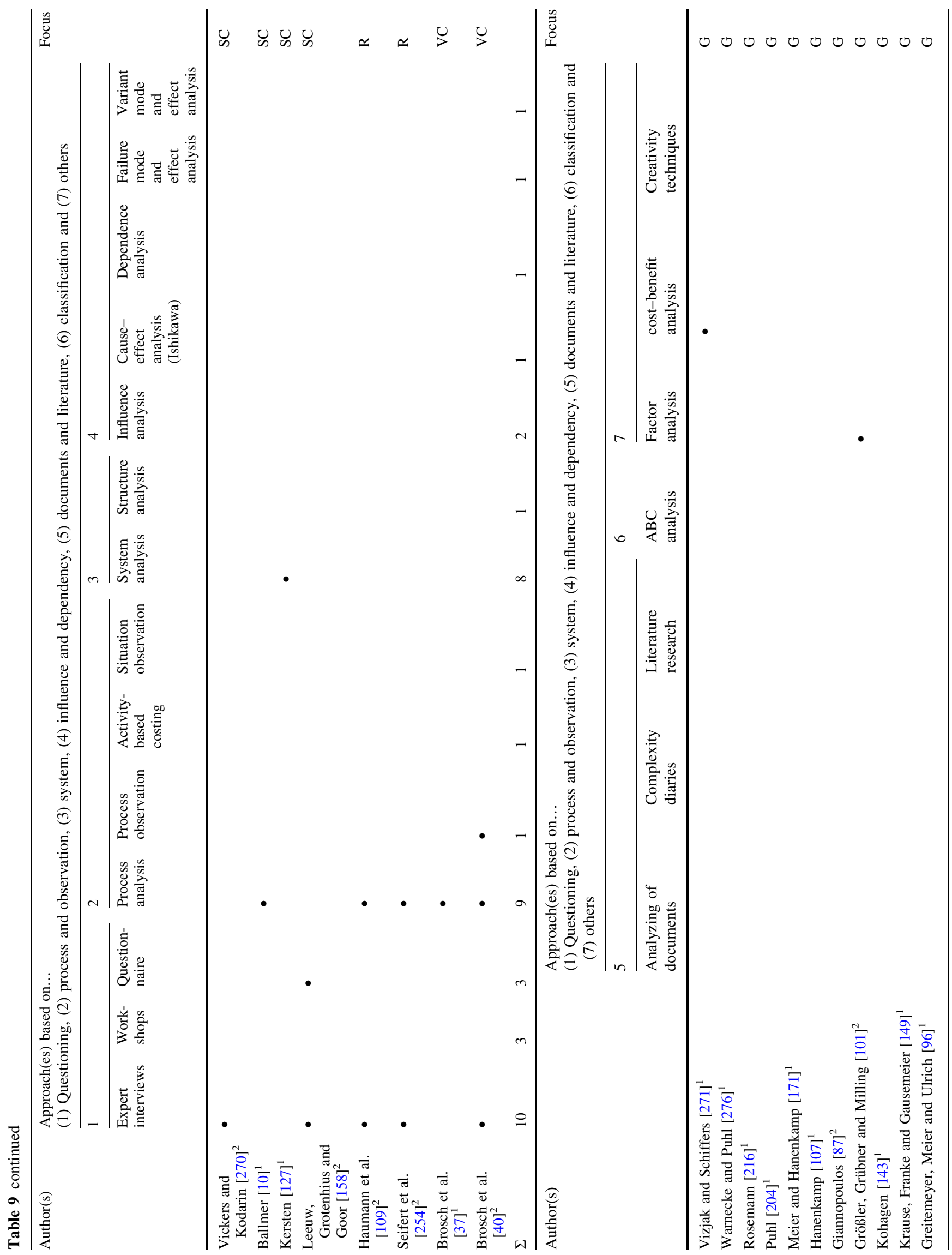




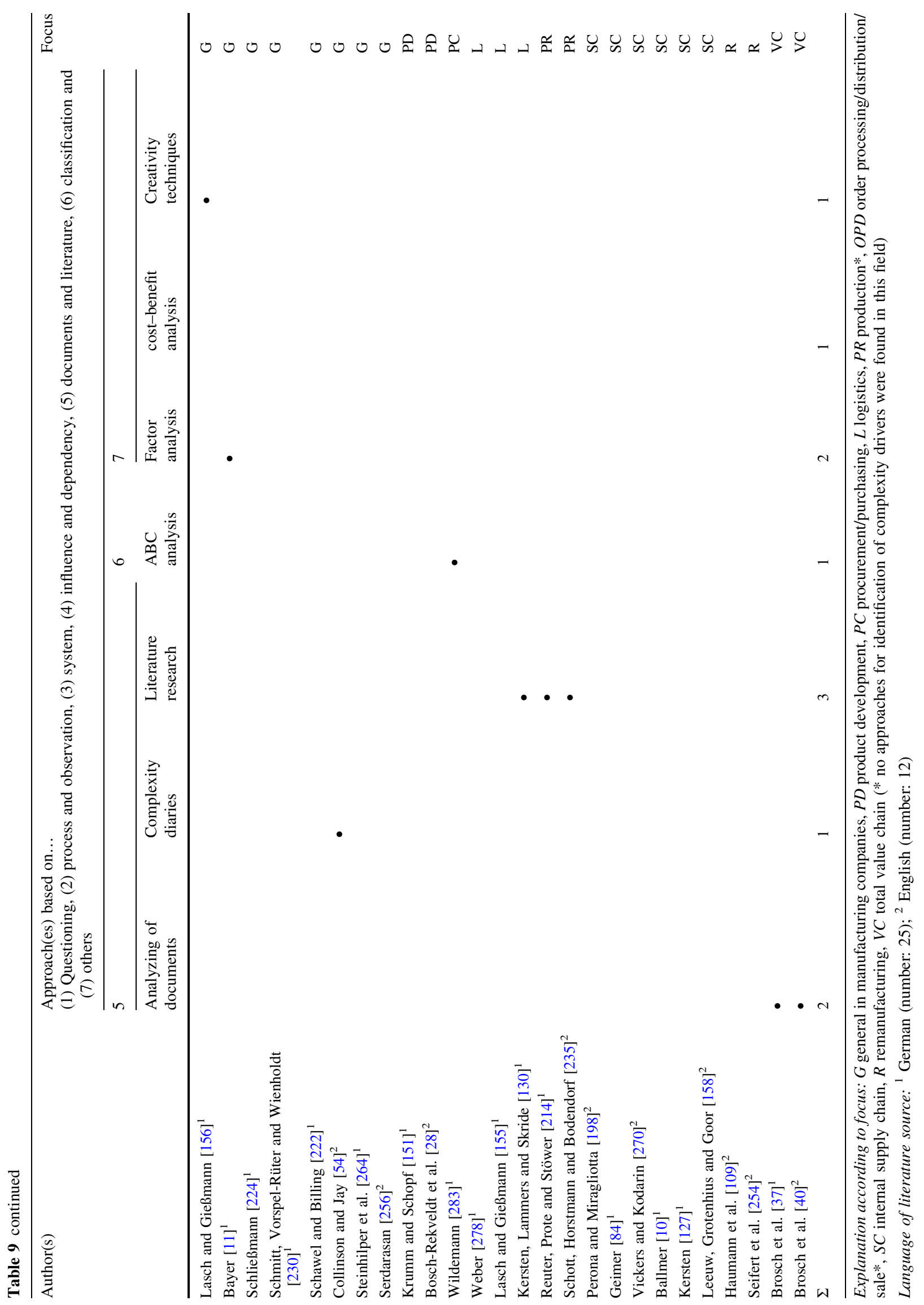


identify the main parts as well as possible weaknesses. $A c$ tivity-based costing is based on the process analysis. The costs are divided into direct and indirect costs to identify cost drivers and thus complexity drivers. Another possibility to identify complexity drivers is to analyze a company's system or structure. During a system analysis, the system is divided into its parts with the objective of identification and analyzing system's behavior and the interdependency between the different parts [149]. The structure analysis is conducted in the same way as a system or a process analysis. To analyze the interdependency between the elements of processes, systems, parts or structures and to identify furthermore the specific complexity drivers, the following approaches are used in the literature: influence analysis, dependence analysis, cause-effect analysis, variant mode and effect analysis and failure mode and effect analysis. These approaches are based on a process, system or structure analysis. A further feasibility to get an overview about a company's complexity and their drivers is to analyze the scientific literature or the existing documents in the company as well as complexity diaries. Complexity diaries are used by the management and employees to document all causes of complexity in the company [54]. In the existing literature, four authors use these approaches for identifying complexity drivers. $\mathrm{ABC}$ analysis is also applied for identification of complexity drivers. Wildemann [283] uses ABC analysis in combination with a system analysis in the field procurement and logistics. As a result of this analysis, the goods or components, which occur at any rate, but have the highest complexity in the system, are the complexity drivers. Other approaches for identification of complexity drivers are the factor analysis, the cost-benefit analysis and creativity techniques. The factor analysis is a multivariate statistical method used to describe variability based on an empirical research. The objective is to concentrate the high number of variables to a lower number, called factors. These factors are the main determining components in a system [41] and thus the complexity drivers. In the literature, the cost-benefit analysis is also used to identify complexity drivers according to a company's performance. As a result of a cost-benefit analysis, the objects with the highest costs and lowest benefit can be identified as the complexity drivers [271]. The creativity techniques in combination with other approaches are also used for complexity driver's identification, but no specific creativity method is referred to in the literature.

\subsubsection{Operationalization and visualization of complexity drivers}

After identification of complexity drivers, the next step for a target-oriented complexity management is to operationalize and visualize the complexity drivers. Based on the literature analysis, seventeen authors and eight different approaches were identified for operationalization of complexity drivers. For visualization of complexity drivers, nineteen authors and eight approaches were found. The most applied approach in both areas is the classification and driver matrixes. Table 10 presents an overview of the identified approaches and the fields. Some authors combine different approaches to operationalize complexity drivers.

The identified approaches for operationalization and visualization were also clustered into seven fields based on their principle to increase transparency and understanding. Again, this is just a mere reflection of the approaches found in the literature without an evaluation of their application in practice. However, it can be seen that some approaches, like the classification and driver matrixes and the cluster analysis, are used for both visualization and operationalization. Further research may include the evaluation of the application of different approaches in practice and their precise fields of application. Because some approaches are used for both visualization and operationalization, it is not clear how these approaches are used and clarification through further research is needed.

The most applied approach in scientific literature for operationalization and visualization of complexity drivers is the classification or driver matrix. Here, the complexity drivers are grouped and evaluated according to their influences, dependencies and effects. Based on the evaluation results, complexity drivers can be visualized in a portfolio diagram to identify critical complexity drivers.

To identify and operationalize the influences, dependencies and effects of complexity drivers, some authors use an influence or system analysis. Based on an influence or system analysis, further methods for visualization of complexity drivers in the field of classification are the complexity vector and the cause-effect diagram, named Ishikawa diagram. Compared to Ishikawa, the complexity vector is more complex and difficult. Generating complexity vectors, Kersten, Lammers and Skride [130] classify complexity drivers in the two dimensions micro and macro, based on their system's influence and the results of a cluster analysis. In this case, the cluster analysis is applied to operationalize and classify the complexity drivers in related groups to increase transparency. Further methods for operationalization of complexity drivers are expert interviews, factor analysis, scoring methods and portfolio methods.

Based on a system's structure, three different approaches for visualization of complexity drivers are applied: descriptive model, variant tree and swimlane diagram. The descriptive model is used to describe a system's complexity, whereby the drivers can be visualized. With variant trees and swimlane diagrams, the complexity drivers can be organized in a hierarchical structure. Based on the evaluation of complexity drivers using scoring methods, the 


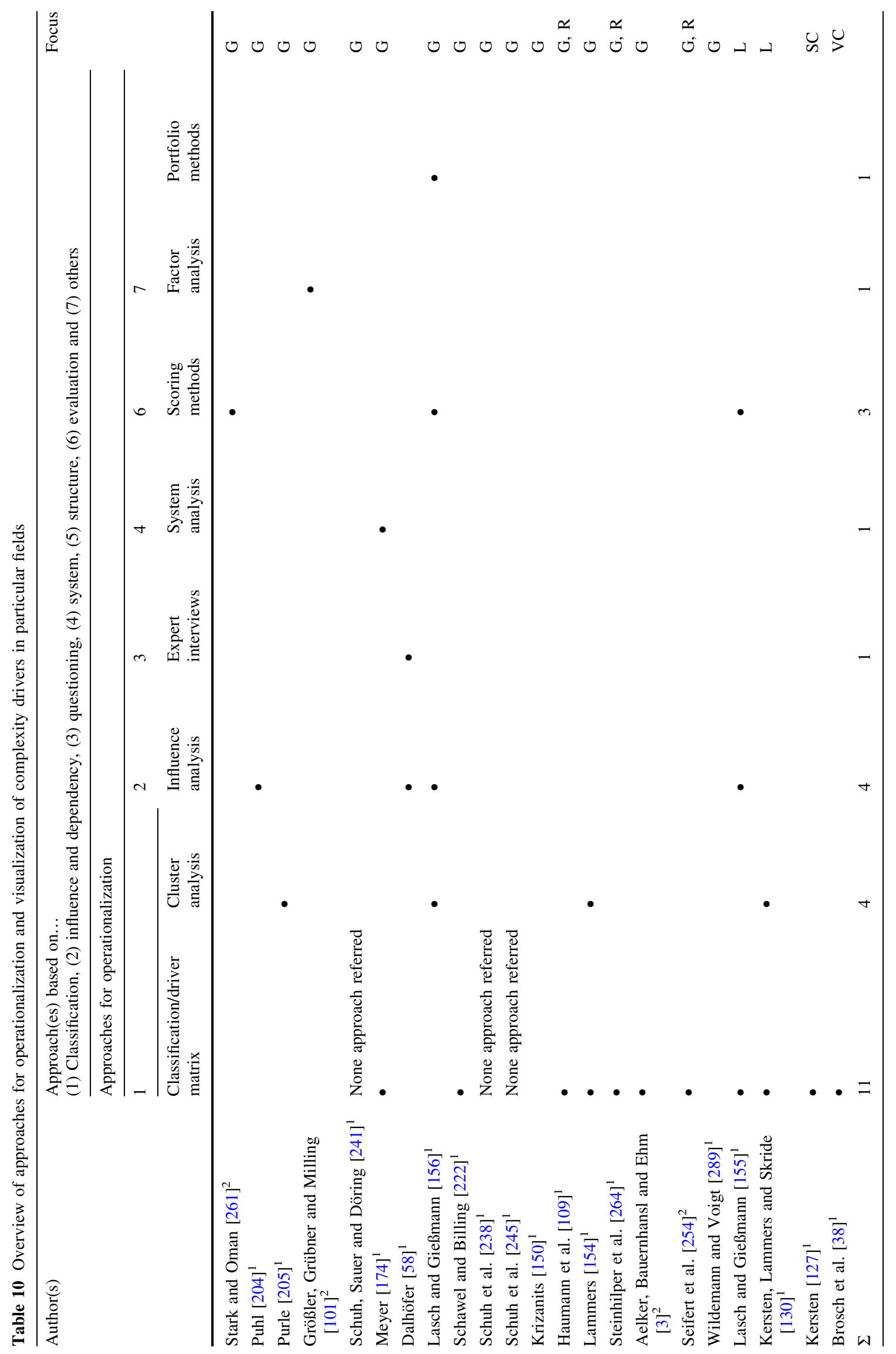




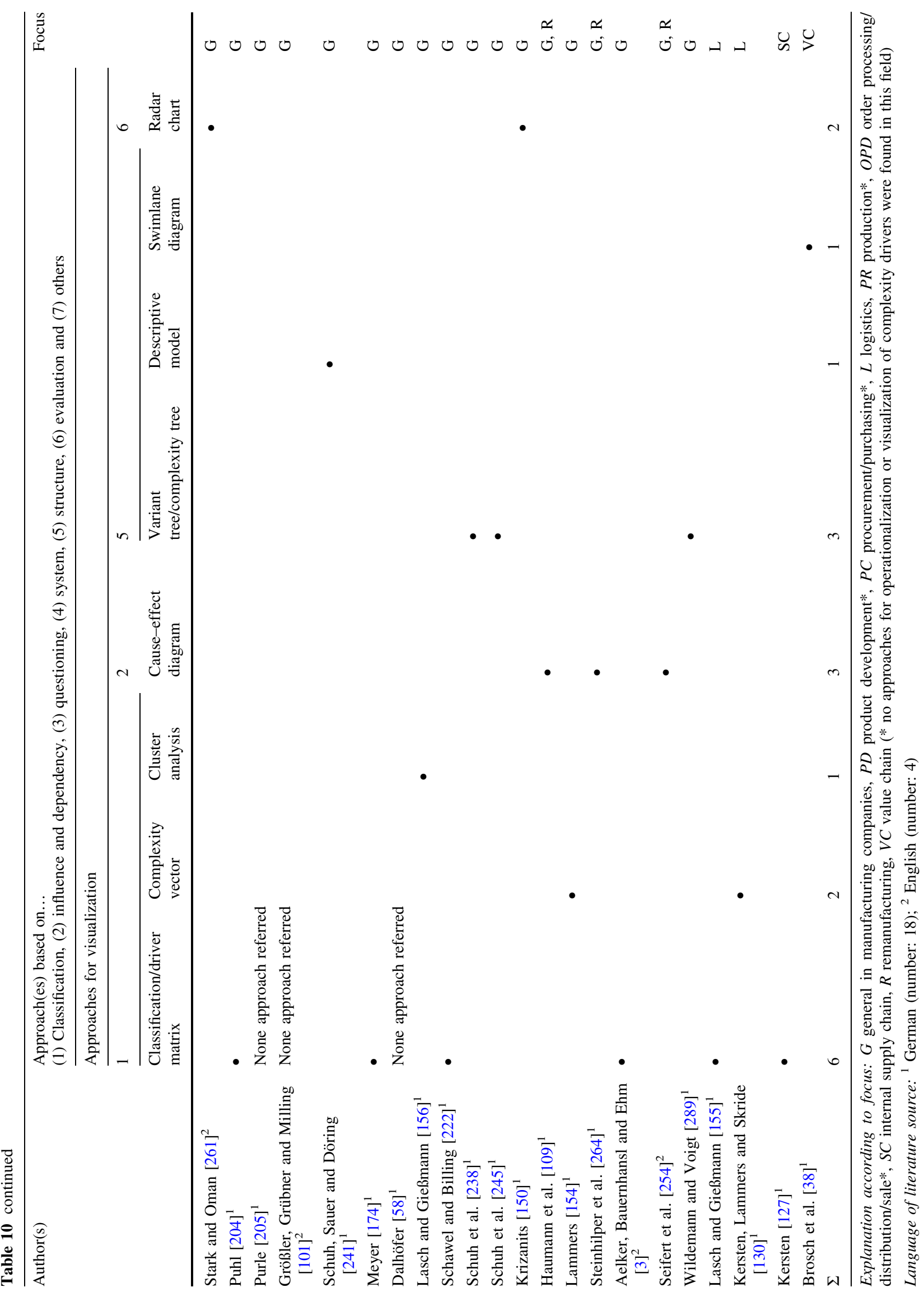


radar chart can also be applied for visualization of complexity drivers in an easy way.

\subsection{Complexity drivers in manufacturing companies and along the value chain}

As already mentioned, complexity drivers have influence on companies and the total value chain [240]. According to the origin, complexity can be separated in internal and external parts [21, 129, 292], called internal and external complexity drivers. Internal and external complexity drivers are connected directly and induce system's complexity [12, 54, 94, 97, 101]. Consequently, internal and external complexity drivers cannot be separated selectively and operationalized [26, 94, 227, 239].

Bliss [22, 23] follows the categorization of internal and external complexity drivers in principle, but he extends the idea and differentiates internal complexity drivers in correlated and autonomous complexity drivers. Correlated complexity drivers have a direct correlation to the external market's complexity and are influenced by it. Autonomous complexity drivers are not influenced by external factors. They are determined by the company itself. In the literature, fifteen authors apply the differentiation of Bliss in their publications (Appendix Table 14). Furthermore, Curran, Elliger and Rüdiger [57] conclude that it is required to separate the complexity drivers in value-adding and non-value-adding drivers. Mahmood, Rosdi and Muhamed [165] argue that "in measuring cost of complexity, the decision is to find the complexity driver that invested more cost but does not contribute much to customer's buying decision".

\subsubsection{Internal complexity drivers}

Internal complexity drivers describe the company's complexity and can be influenced actively by the company itself [3, 18, 23, 29, 127-129, 200, 205, 282]. They occur as a result of external complexity drivers or are induced by the company itself $[54,95,107,111,154,217,279]$. Götzfried [94] argues that internal complexity is a translation of external complexity, which is induced exclusively by the company. Wildemann [281] separates internal complexity drivers in three categories: structural, informational and individual complexity drivers.

\subsubsection{External complexity drivers}

External complexity drivers are factors, which influence the company's complexity directly from outside [3, 18, 54, 90, 111, 118, 127-129, 140, 201, 205, 281, 282]. Bohne [26] and Klepsch [140] describe that external complexity produces internal complexity as a reaction. Piller [201] defines external complexity as a "mirror picture" of the market's requirements. Normally, external complexity drivers are constant and cannot or nearly cannot be influenced by the company itself because they are not induced by the company $[17,18,29,90,94,127$, 129, 154, 200, 279].

To handle external complexity, companies typically respond with an unwanted increase in internal and accordingly non-value-adding complexity [12, 54, 59, 95, 96, 201, 284]. Größler, Grübner and Milling [101] argue that external complexity drivers force the company to build up internal complexity.

\subsubsection{Complexity driver's classification system}

Managing complexity in companies requires the identification of complexity sources. Lasch and Gießmann [155] describe that the complexity sources and their effects are various. Thus, a complete list of all sources cannot be specified. In the literature, more than 480 different complexity drivers were found during our research in 223 literature parts concerning complexity drivers in manufacturing companies and along the value chain. For a better understanding and overview, Schöttl, Herrmann, Maurer and Lindemann [236] suggest that complexity drivers "have to be aggregated to a small, abstract and well-defined collection". To increase transparency, Klagge and Blank [137], Wildemann [282], Lasch and Gießmann [155, 156] and Gießmann [88] follow this approach and also separate their identified complexity drivers in different clusters according to their origin, characteristic and influences on other drivers. The framework for the classification system used in this paper is based upon existing classification systems in the literature provided by different authors. To create a superior classification system without overlaps between the different complexity driver categories, we analyzed and synthesized the existing systems as follows:

In their research, Bliss [22, 23], Kirchhof [134], Hasenpusch, Moos and Schwellbach [108], Keuper [132], Marti [168], Mayer [170], Lasch and Gießmann [155], Gießmann [88], Gießmann and Lasch [90], Schömann [232], Götzfried [94], Schoeneberg [233], Grimm, Schuller and Wilhelmer [97] and Lammers [154] cluster complexity drivers according to their origin into external and internal drivers. Furthermore, they separate the internal drivers into internal correlated and internal autonomous complexity drivers. Schubert [237] argues that external complexity comprises complexity drivers from a market-based view and internal complexity comprises drivers from a resourcebased view. 

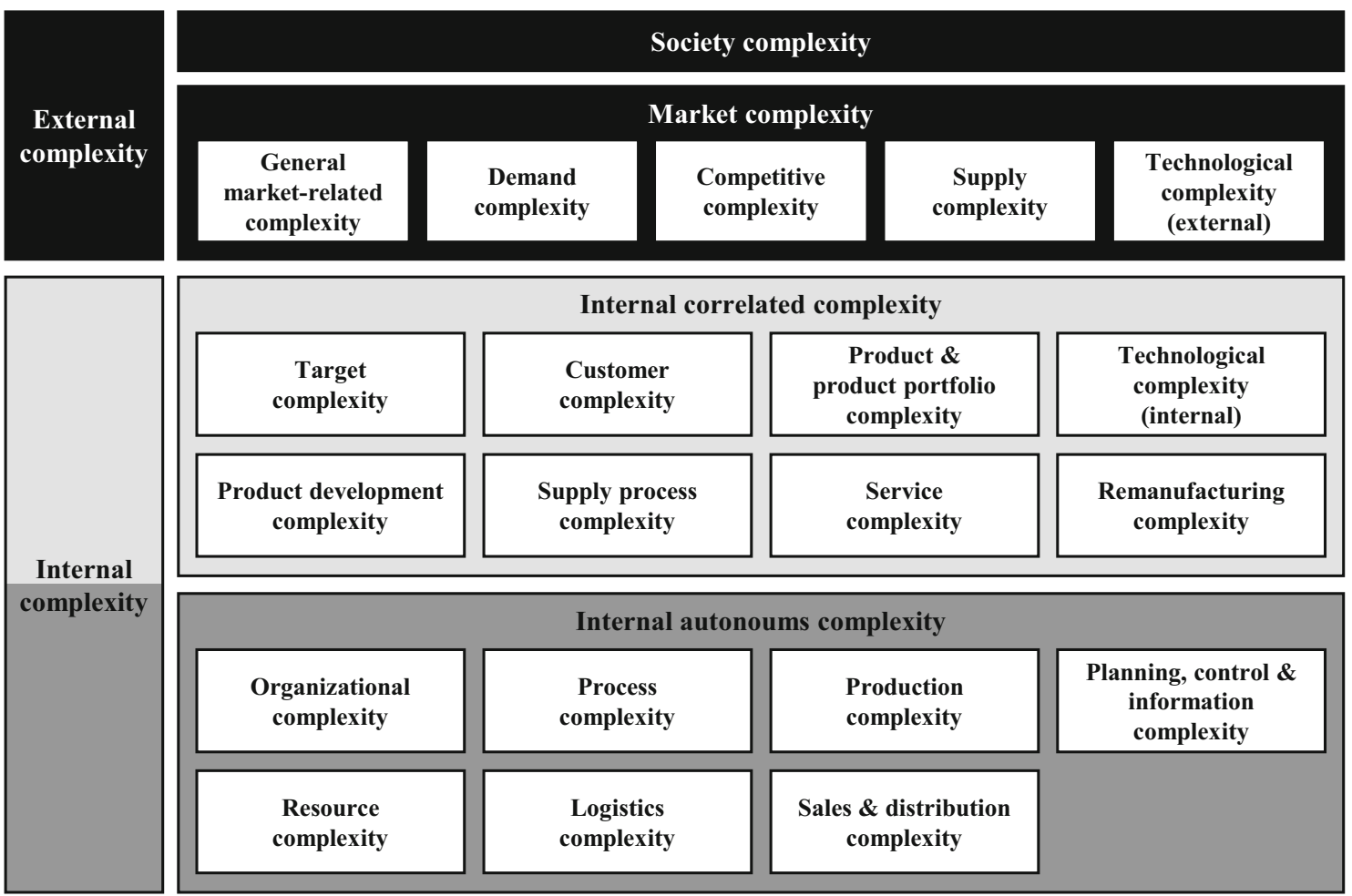

General

complexity

Fig. 7 Complexity driver's classification system

In our study, we followed the already mentioned classification and divide our classification system into the two main categories: internal and external complexity drivers. Further, we also divided the internal complexity drivers into internal correlated and internal autonomous complexity drivers (see Fig. 7).

In the literature, Keuper [132], Marti [168], Lasch and Gießmann [155], Gießmann [88], Gießmann and Lasch [90], Schoeneberg [233], Grimm, Schuller and Wilhelmer [97] and Ruppert [218] subdivide external complexity into society complexity and market complexity. Society complexity is determined by cultural factors (language, working hours, habit, working method, education), ecological factors, legal factors, standards and regulations and political factors. The list with all identified complexity drivers in this and all other categories, which will be mentioned, is shown in "Appendix" (see Table 15). Asan [6] and Serdarasan [255] use the term geopolitical complexity synonymously for society complexity. However, in the literature most of the authors use the term society complexity, which is the reason why we followed this nomenclature. In the literature, market complexity is further subdivided into different subcategories. Keuper [132], Lasch and Gießmann [155], Gießmann [88], Gießmann and
Lasch [90], Schoeneberg [233], Grimm, Schuller and Wilhelmer [97] assign the subcategories demand complexity, competitive complexity and supply complexity to this subcategory. Bliss [22, 23], Marti [168], Schömann [232] and Blockus [24] follow this assignment and extend the subcategory by adding technological complexity (external). In the literature, we found several single marketrelated complexity drivers, which cannot be assigned to the previously mentioned categories. Thus, we introduced a new category called general market-related complexity.

As already mentioned, in our research, we divided the main category internal complexity into the subcategories internal correlated and internal autonomous complexity. Bliss [23], Lasch and Gießmann [155], Gießmann [88], Gießmann and Lasch [90], Schömann [232] and Marti [168] assign the following complexity driver categories to the subcategory internal correlated complexity: target complexity, customer complexity as well as product and product portfolio complexity. Keuper [132], Schoeneberg [233] and Grimm, Schuller and Wilhelmer [97] follow this assignment and extend the subcategory by adding technological complexity (internal). Other authors have added further complexity driver categories to the subcategory internal correlated complexity. However, these categories 
could not be allocated to the existing categories; thus, they became independent categories within the subcategory internal correlated complexity. Bayer [11], Dehnen [59], Kim and Wilemon [133] and Wildemann and Voigt [289] add the category product development complexity, and Bayer [11], Blockus [24] and Nurcahya [179] add the category supply process complexity to the mentioned subcategory. The subcategory internal correlated complexity is completed by adding the categories service complexity and remanufacturing complexity. Service complexity is added by Schmidt [228], Collinson and Jay [54] and Dalhöfer [58]. Remanufacturing complexity is added by Bayer [11], Haumann et al. [109], Steinhilper et al. [264], Seifert et al. [254] and Butzer et al. [48]. In summary, the subcategory internal correlated complexity comprises eight complexity driver categories: target complexity, customer complexity, product and product portfolio complexity, technological complexity (internal), product development complexity, supply process complexity, service complexity and remanufacturing complexity.

In the next step, the subcategory internal autonomous complexity is defined. Lasch and Gießmann [155], Gießmann [88], Gießmann and Lasch [90], Schoeneberg [233], Grimm, Schuller and Wilhelmer [97] and Schömann [232] assign the categories organizational complexity and process complexity to the subcategory internal autonomous complexity. Lasch and Gießmann [155], Gießmann [88], Gießmann and Lasch [90] and Schoeneberg [233] extend the subcategory by the category structure complexity. However, several authors such as Asan [6], Serdarasan [255], Reiß [213], Blockus [24], Wildemann and Voigt [289], Höge [118], Blecker, Kersten and Meyer [21], Kersten et al. [129], Schubert [237], Collinson and Jay [54], Schuh, Gartzen and Wagner [244], Götzfried [94], Ruppert [218], Schulte [249], Lindemann, Maurer and Braun [160] and Größler, Grübner and Milling [101] include structural complexity drivers in the category organizational complexity. To avoid overlaps in our classification system, we also assigned structural complexity drivers to the category organizational complexity. Other important categories, which are added to the subcategory internal autonomous complexity, are the production complexity and planning, control and information complexity. In the literature, production complexity is defined by Bliss [22, 23], Bayer [11], Mayer [170], Keuper [132], Gießmann and Lasch [90], Lasch and Gießmann [155], Schömann [232], Blockus [24], Marti [168], Klepsch [140], Pepels [197], Ruppert [218], Gronau and Lindemann [98], Westphal [280], Jäger et al. [123], Götzfried [94], Schulte [248] and Schmidt [228]. The category planning, control and information complexity is defined by Keuper [132], Mayer [170], Gießmann and Lasch [90], Lasch and Gießmann [155], Schömann [232], Schoeneberg [233],
Ruppert [218], Klagge and Blank [137], Jäger et al. [123], Gullander et al. [105], Grimm, Schuller and Wilhelmer [97] and Hermann [115]. Furthermore, the categories resource complexity, defined by Höge [118], Reiners and Sasse [210] Bohne [26], logistics complexity, defined by Klagge and Blank [137], and sales and distribution complexity, defined by Bayer [11] and Klepsch [140], are added to the subcategory internal autonomous complexity. In total, the subcategory internal autonomous complexity comprises seven complexity driver categories: organizational complexity, process complexity, production complexity, planning, control and information complexity, resource complexity, logistics complexity and sales and distribution complexity.

As already mentioned, complexity drivers are separated according to their origin into external and internal complexity drivers. In the literature, a further superior classification system exists. Denk and Pfneissl [62] separate the complexity drivers in two main groups: general complexity drivers (e.g., transparency, uncertainty) and precise complexity drivers (e.g., organizational complexity, process complexity, technological complexity). General complexity drivers are also referred to by Mayer [170], Reiß [212, 213], Berens and Schmitting [14], Hermann [115], Gronau and Lindemann [98], Kolbusa [144, 145], Schmitt, Vorspel-Rüter and Wienholdt [230], Kersten et al. [129], Blecker, Kersten and Meyer [21], Bick and Drexl-Wittbecker [16] and Waldthausen [273]. Thus, we included a third main complexity category called general complexity in our classification system. The total classification system is shown in Fig. 7.

After defining the superior complexity driver classification system, we assigned the complexity drivers found in the literature to these previously defined main groups and categories. According to the literature, we clustered the identified complexity drivers (more than 480) into:

- three main groups (external complexity, internal complexity and general complexity)

- four subcategories (society complexity, market complexity, internal correlated complexity and internal autonomous complexity) and

- twenty-two main complexity driver categories (society, demand, competitive, supply, technological external, target, customer, product and product portfolio, technological internal, product development, supply process, service, remanufacturing, organizational, process, production, planning, control and information, resource, logistics, sales and distribution, and general complexity) depending on their origin, characteristic and influences on other drivers. The subcategory society complexity and the main group general complexity are also added to the twenty-two main 


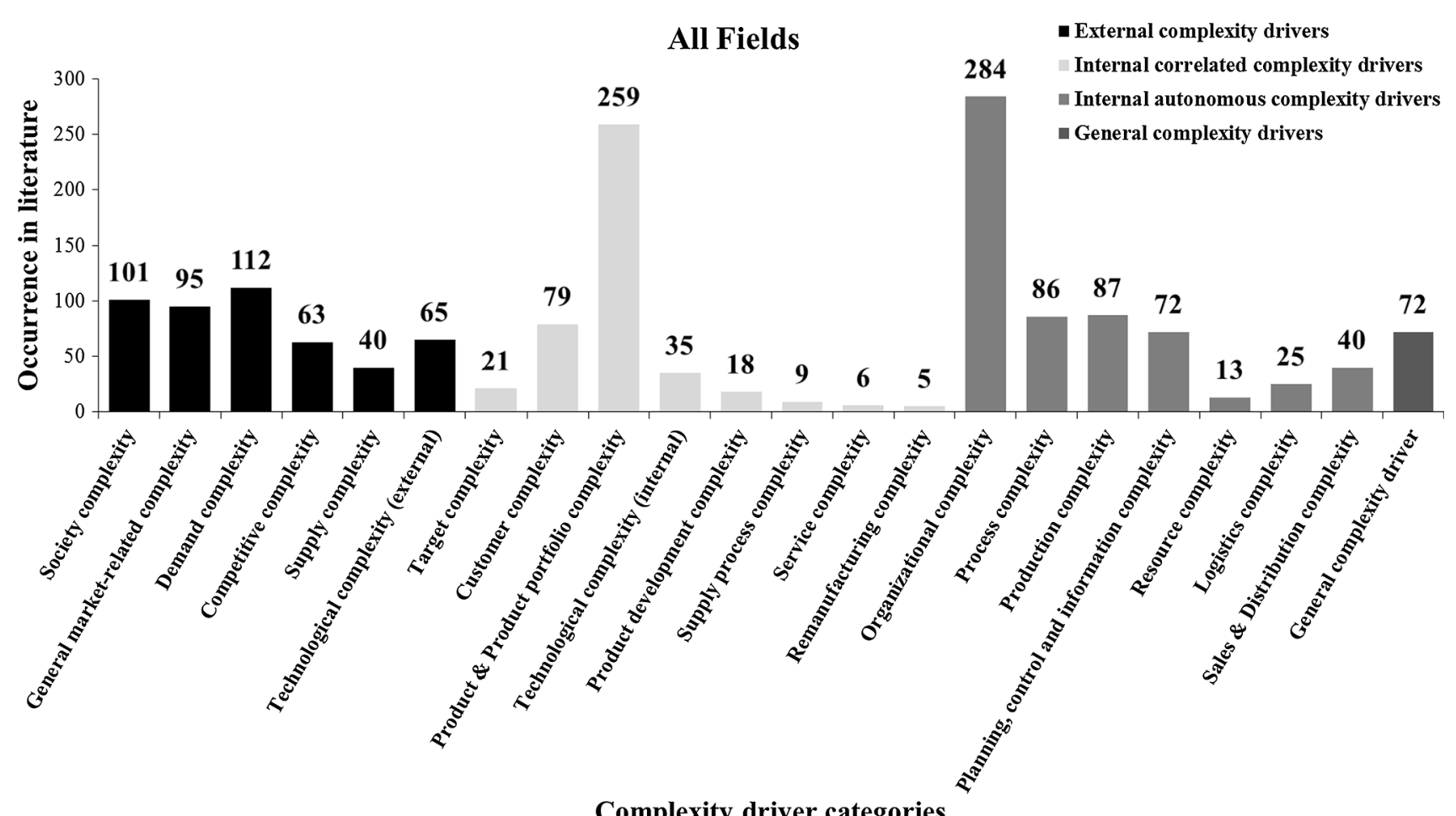

Fig. 8 Overview about complexity driver's clustering and their occurrence in the literature

complexity driver categories, because they cannot be further subdivided into different driver categories. Thus, we added the identified single complexity drivers directly to these two categories.

For complexity driver's clustering, we analyzed all identified drivers and summarized them according to their context and similarities in a superior complexity driver category. As already mentioned, this framework is based on the literature. For example, in the category "Society complexity", we identified the following seven single complexity drivers and aggregated them to the mentioned superior category: social framework, social requirements, social change, social behavior, cultural framework, cultural factors (language, working hours, habit, working method, education) and cultural differences. In the category "Technological complexity (external)", we identified the following nine single complexity drivers, which were also aggregated to the mentioned superior category: technological progress, technological change, different technological standards, technological innovations, technological intensity, technological dynamics, new technologies and materials, combination of different technologies and technology integration. In the main group "general complexity", we aggregated all complexity drivers, which cannot be assigned to the other two main groups and four subcategories. In the main group "general complexity", we assigned twenty-eight single complexity drivers such as stability, instability, perception, time, costs, quality, flexibility, cost effectiveness and transparency. For the other complexity driver categories, we performed the clustering process analogously. Figure 8 presents the clustered twenty-two main complexity driver categories and their occurrence in the literature in all fields (general in manufacturing companies and along the value chain). Table 15 in "Appendix" shows the different complexity drivers in each category and group.

To answer the third research question, we separated the data from Fig. 8 into the different fields general in manufacturing companies and along the value chain. As a result of Table 11, some fields are influenced by more complexity drivers than other fields. The amount of complexity drivers in a system reflects the level of difficulty in managing a system's complexity, because complexity drivers have a high influence on a system's complexity. Complexity drivers are strictly connected with their category. For a targetoriented complexity management, it is necessary to handle all complexity drivers in a certain category of a specific system. In an overall view, it can be summarized that system's complexity is influenced by the complexity driver categories. For example, the field production is influenced by fifteen complexity driver categories, while remanufacturing is influenced by seven complexity driver categories. Thus, the implementation of a target-oriented complexity management in the field production is more difficult than in 


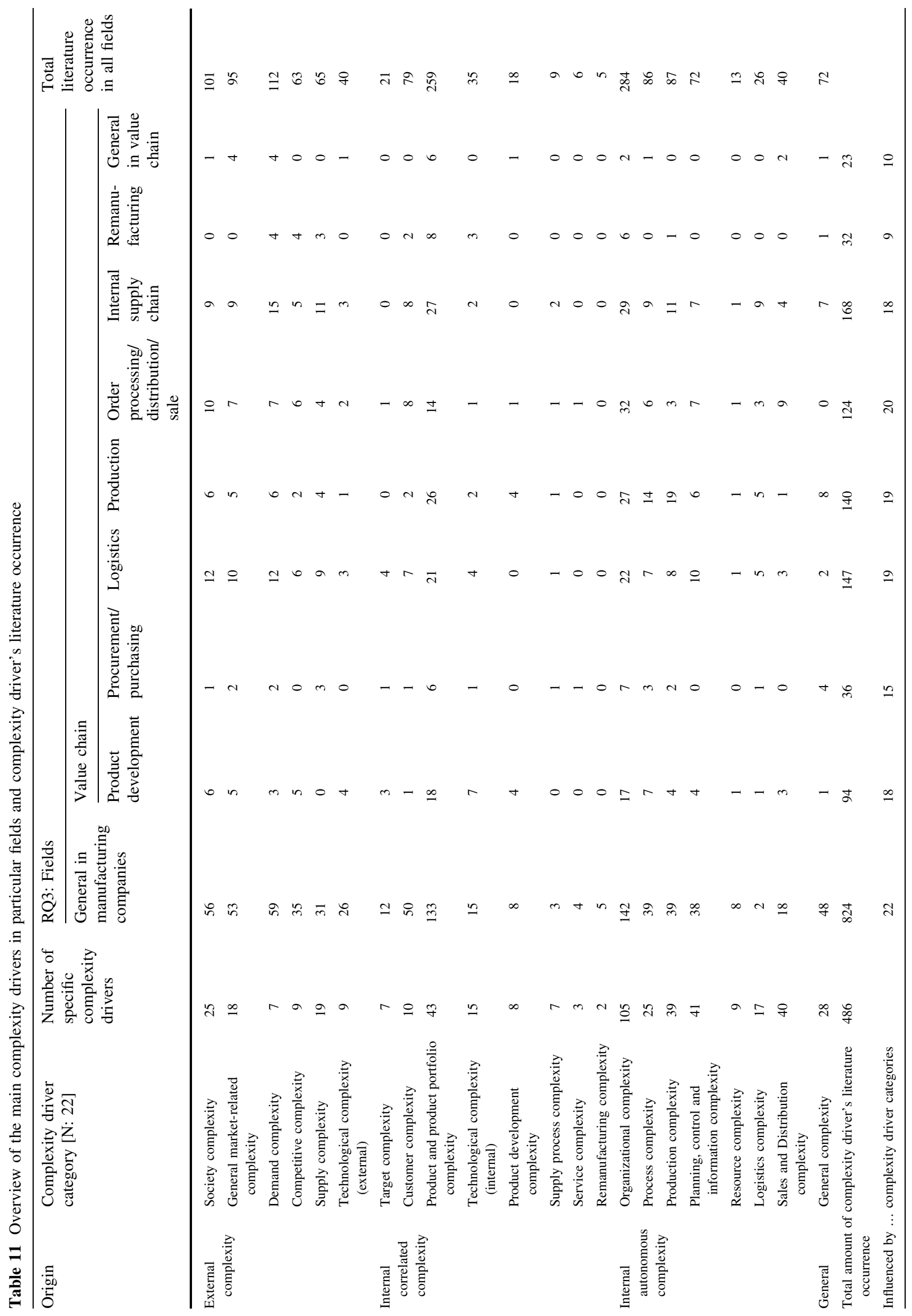


the field remanufacturing, because more complexity sources must be considered. As also seen in Table 11, market complexity, product and product portfolio complexity and organizational complexity are complexity driver categories that influence all fields in manufacturing companies. Thus, these categories are the most important in the company and must be managed first for a target-oriented complexity management. Another important category which has an influence on many fields in the company is society complexity. This category must also be managed for a targetoriented complexity management. Furthermore, all fields are influenced by internal and external complexity driver categories. However, the different fields are mostly influenced by internal driver categories, which can be influenced actively by the company itself. When further investigating the different fields, it can be seen that the fields general in manufacturing companies, logistics, production, order processing/distribution/sale and internal supply chain are mostly influenced by internal autonomous complexity driver categories. Internal autonomous complexity driver categories are not influenced by external factors and are determined by the company itself. In contrast, the field remanufacturing is influenced mostly by internal correlated complexity driver categories. The internal correlated complexity driver categories have a direct correlation to company's environment (e.g., market and society) and are influenced by it. The fields product development, procurement/purchasing and general in value chain are influenced almost to the same extend by internal correlated as well as internal autonomous complexity driver categories.

In the next step, we tried to identify the main complexity driver categories in the referred fields. In the literature, the following approaches are applied to identify the most important factors among many factors: factor analysis [9, 41], factor screening [139], DoE-design of experiments [259] and Pareto-analysis [135].

The factor analysis is a statistical method and used for data reduction in an empirical research or experiments. The aim is to get a small set of variables from a large set of variables to identify the most important factors [9, 41]. Kleijnen [139] uses the factor screening method in simulation experiments to identify the most important factors: "Factor screening [...] means that the analysts are searching for the most important factors among the many factors that can be varied in their experiment" [139]. For screening, Kleijnen [139] uses different screening designs to treat the simulation model as a black box. Another method to identify variables, which have the most influence on other variables or parameters in an experiment, is the design of experiments (DoE). The DoE is normally used for the development and optimization of products and processes [259]. Another approach for identification and separation of the most important factors among many factors is the Pareto-analysis. The Pareto-principle describes that $80 \%$ of the effects come from $20 \%$ of the causes [135]. All of the mentioned principles can be used to identify the most important factors, variables or inputs. However, none of these approaches were applicable to identify the main complexity driver categories in our opinion. The approaches factor analysis, factor screening and design of experiments are based on experiments, whereas the Pareto-principle can be used more generally without experiments. The Pareto-principle is based on effects and causes. Transferred to our research, the cause would be the number of a complexity driver's categories appearance in the literature and the effect would be the importance of the specific category. Since it would be naïve to derive the importance of a specific complexity driver's category from its number of appearances in the literature, this principle also wasn't applicable. Further research is necessary to identify an approach for analyzing and identifying important complexity driver categories.

\section{Conclusion and outlook}

Before starting our research, we reviewed the literature and searched for existing literature studies about complexity drivers and gaps in the literature. As a result of our literature search, we identified four literature studies about complexity drivers, which have been done by Meyer [174], Serdarasan [255, 256] and Wildemann and Voigt [289]. After identification, the previous literature studies were analyzed and evaluated based on the following eleven criteria (see also Table 4): type of literature study, focus; research period; amount of identified literature sources, complexity driver's definition, described complexity drivers and complexity driver's categories; determination of research questions, databases, search terms and synthesizing methods; and comparison of literature findings' with other literature sources or empirical research data.

The existing studies comprise several literature sources in the period between 1991 and 2011. However, a systematic, explicit and reproducible method for literature's identification, evaluation and synthesizing is not described. To describe the current state of knowledge in a particular field of research, it is essential to determine the research questions, databases, search terms, the synthesizing methods and to compare the findings with other literature sources. Only Wildemann and Voigt [289] and Serdarasan [256] compare their findings with the findings of other literature sources. Another important criteria for the scientific research are the specification of the different literature sources about complexity drivers, the trends in the literature over the last years and the gaps in the literature 
for future research. These requirements are not fulfilled in the previous literature studies. Furthermore, only the fields logistics, supply chain and general in manufacturing companies are described. In the literature, an overview regarding complexity drivers general in manufacturing companies and in all parts along the value chain does not exist so far. Another deficit in the existing studies is that they present only one definition of complexity drivers. In our opinion, different definitions of complexity drivers should be analyzed, compared and discussed to identify all characteristics of complexity drivers. In the already mentioned studies, no approaches for identification and operationalization are described. Only one method for complexity driver's visualization is described by Wildemann and Voigt [289]. For the researcher, it is important to know that a complexity driver is and what approaches can be applied for complexity driver's identification, operationalization and visualization. Our purpose is to provide an overview about different definitions and methods for complexity driver's identification, operationalization and visualization for closing these research gaps. In addition, we develop a new overall definition of complexity drivers to summarize all characteristics.

To provide this literature review and to fulfill the all requirements, we used the methodology of Fink [78]. The research method is described in Sect. 2. First, we started our research process by defining our research questions, which guide the literature review. The search term was defined by finding the lowest common denominator of the many different paraphrases of the term complexity driver that exist in the literature. Then, we defined our databases. For our research, we defined our search terms in English and German to extend the results and to prevent the elimination of important articles. The literature search was performed in eight English and German databases and resulted in 11.425 literature sources. For analyzing and synthesizing the literature, we followed the approach of the qualitative content analysis. The synthesizing process finally resulted in 235 relevant papers in the time period between 1991 and 2015. Before 1991, no relevant literature sources according to the issue complexity drivers were found in our research. The reasons could be attributed to complexity management's evolution over the last 25 years and the principal definition and understanding of the term "complexity driver". Analyzing the overall trend of the literature regarding complexity drivers in manufacturing companies and along the value chain shows an increased interest throughout the last 10 years (see Fig. 5). Seventyfour percent of all publications were published between 2004 and 2015. More than 50\% of all the publications about complexity drivers were published in journals and $\mathrm{PhD}$ theses. Thus, complexity drivers have a high importance in scientific research. In our research, we found out that 212 papers described specific complexity drivers in manufacturing companies and along the value chain. After analyzing and synthesizing these papers, we identified 223 different literature parts concerned with complexity drivers in the two categories manufacturing companies (108 parts) and along the value chain (115 parts). Eleven papers describe both parts. The trends of the two categories during the last 25 years show that there is an increasing interest in complexity drivers along the value chain in scientific literature in the last 10 years (see Fig. 6). However, the most publications general in manufacturing companies were published between the years 1998 and 2010. Comparing these trends shows that complexity drivers are now described more in detail regarding different parts along the value chain. This indicates that complexity drivers gain more and more importance for scientific research. In the next step, the data from the category complexity drivers along the value chain were separated in the following eight different fields and analyzed: product development (PD), procurement/purchasing $(P C)$, logistics $(L)$, production $(P R)$, order processing/distribution/sale (OPD), internal supply chain $(S C)$, remanufacturing $(R)$ and general in value chain $(V C)$. The analysis shows that the amount of publications about complexity drivers in all eight different fields has increased over the last 10 years.

This paper describes a variety of definitions and methods for identification, operationalization and visualization of complexity drivers. Within the last decades, complexity has increased continuously in many industries, caused by internal and external sources named complexity drivers. Identifying, analyzing and understanding complexity drivers are the first steps in developing and implementing a clear strategy to handle complexity in the company. For an effective complexity management, it is necessary to know the key drivers of complexity in a system, because they are the main adjusting levers for company's success. Furthermore, managing a system's complexity requires an optimum fit between internal and external complexity. Thus, complexity drivers play a significant role for complexity management and are a strategic issue for companies to be competitive.

For this literature review, we determined three research questions, which were answered as follows. Before identification, it is necessary to understand what a complexity driver is [144, 174]. To answer the first research question, the identified literature was analyzed and synthesized. The researched literature contains several different definitions of complexity drivers, defined by thirty-six authors. Based on their content, the definitions can be assigned to five main categories: factors, indicators, sources, parameters/variables and symptoms/phenomenon. As a result, there is no universal understanding of the term "complexity driver", but the identified definitions tend toward similar definitions. To 
generate a general definition of complexity drivers, we analyzed the existing definitions by identifying their hypernyms and differentia. Several different hypernyms for the genus term complexity driver exist in the literature, but we came to the conclusion that only the term factor covers the general understanding of a complexity driver in total. Then, the existing differentia found in the literature were clustered into five groups based on their differences and commonalities. Based on the five groups of differentia and in combination with the hypernym term factor, we generated a more general definition of complexity driver.

A specific and target-oriented complexity management is based on identification, visualization and operationalization of system's complexity drivers. In the literature, several different methods for identification, operationalization and visualization of complexity drivers are applied (see Tables 9, 10). Based on this literature review and to answer the second research question, twenty-one different approaches were identified in the literature for complexity driver's identification, which were focused on different fields. The most applied approaches are expert interviews, process analysis and system analysis. We didn't conduct an evaluation of all existing approaches regarding their practical uses. Our purpose was to reflect the different approaches found in the literature. We identified eight different approaches for operationalization and visualization of complexity drivers in the existing literature. However, a clear assignment of the different approaches to operationalize and visualize complexity drivers wasn't possible in all cases. As a result, the most applied approach in both areas is the classification and driver matrixes. Further research to eliminate this lack of definition is needed as well as an evaluation of the existing approaches' practical application.

Complexity drivers have a direct influence on the company and the value chain. Complexity drivers can be separated in internal and external drivers, depending on their origin. Internal complexity drivers can also be differentiated in correlated and autonomous complexity drivers. In the literature, more than 486 different internal and external complexity drivers were found during our research in 223 literature parts concerning complexity drivers in manufacturing companies and along the value chain. For clustering the 486 complexity drivers, we developed a superior classification system without overlaps between the different complexity driver categories based upon existing classification systems in the literature, provided by different authors. In summary, our new classification system consists of three main groups (external complexity, internal complexity and general complexity), four subcategories (society complexity, market complexity, internal correlated complexity and internal autonomous complexity) and twenty-two main complexity driver categories depending on their origin, characteristic and influences on other drivers (see Fig. 7). The identified 486 complexity drivers were clustered into these complexity driver categories and groups. The assignment to the different categories and groups was done depending on the complexity driver's origin, characteristic and influences on other drivers. Figure 8 presents an overview about the complexity driver categories and their occurrence in the literature. The third research question was answered by means of analyzing the identified literature and synthesizing the complexity driver categories in the referred fields (see Table 11). The basis for synthesizing the categories is shown in Fig. 8.

In summary, our new literature review covers complexity drivers in manufacturing companies and along the value chain over a period of 25 years (1991-2015). It fulfills all requirements in total (see Table 12) and closes the gap in the literature.

In total, 235 literature sources are identified and more than 486 complexity drivers are described and clustered in 39 categories. The research method, including the research questions, databases, search terms and synthesizing methods, and the results and the trends of complexity drivers in the literature and in the different fields over the last 25 years are also described. We compare our results with the findings of previously published literature. Gaps for future research are pointed out.

Furthermore, a new definition of the term "complexity driver" is specified, based on the existing definitions by identifying a general hypernym and clustering existing differentia. Different methods that are applied in the literature for complexity driver's identification, evaluation and visualization are described and give the reader a general overview. A new classification system was developed, and the complexity driver categories and their complexity drivers general in manufacturing companies and along the value chain are pointed out (see Appendix Table 15).

The review was focused only on the manufacturing industry. Future research may also include other sectors or industries such as financing and/or insurance. It would also be interesting to compare the research results from other sectors with the results of this paper. In addition, the findings of this paper should be evaluated regarding their impact and relevance on practice by an empirical research analogously to the empirical research done by Wildemann and Voigt [289]. Further, the different approaches for complexity driver's identification, operationalization and visualization should be evaluated by the practice within an empirical research according to the following three categories: amount of work, data volume and level of difficulty. Also, the different approaches should be evaluated regarding their specific fields of application. This information could encourage the user to find the right approach for his specific field of interest. Further research may also include finding an approach to identify and analyze the 
Table 12 Evaluation of our new literature review about complexity drivers in comparison with existing literature studies

\begin{tabular}{|c|c|c|c|c|c|}
\hline Author(s) & Meyer [174] & $\begin{array}{l}\text { Serdarasan } \\
{[255]}\end{array}$ & $\begin{array}{l}\text { Wildemann } \\
\text { and Voigt [289] }\end{array}$ & $\begin{array}{l}\text { Serdarasan } \\
{[256]}\end{array}$ & $\begin{array}{l}\text { New literature } \\
\text { review }\end{array}$ \\
\hline Type of literature study & Overview & Review & Overview & Review & Review \\
\hline \multicolumn{6}{|l|}{ Focus } \\
\hline General in manufacturing companies & $\bullet$ & & $\bullet$ & & $\bullet$ \\
\hline Product development & & & & & $\bullet$ \\
\hline Procurement/purchasing & & & & & $\bullet$ \\
\hline Logistics & $\bullet$ & & & & $\bullet$ \\
\hline Production & & & & & $\bullet$ \\
\hline Order processing/distribution/sale & & & & & $\bullet$ \\
\hline Internal supply chain & & $\bullet$ & & $\bullet$ & $\bullet$ \\
\hline Remanufacturing & & & & & $\bullet$ \\
\hline General in value chain & & & & & $\bullet$ \\
\hline Research period & 1992-2004 & $1998-2011$ & $1991-2010$ & 1992-2011 & 1991-2015 \\
\hline \multicolumn{6}{|l|}{ Literature review's results: amount of... } \\
\hline Identified literature sources & 19 & 25 & 17 & 38 & 235 \\
\hline Complexity driver's definitions & 1 & 1 & 1 & 1 & $18+1$ \\
\hline Described complexity drivers & 127 & 27 & 95 & 32 & 486 \\
\hline Complexity driver categories & 14 & 3 & 11 & 9 & 22 \\
\hline \multicolumn{6}{|l|}{ Determination of $\ldots$ by the author(s) } \\
\hline Research questions & - & - & - & - & ++ \\
\hline Databases & - & - & - & - & ++ \\
\hline Search terms & - & - & - & - & ++ \\
\hline Synthesizing methods & - & - & - & - & ++ \\
\hline \multicolumn{6}{|l|}{ Literature findings' comparison with... } \\
\hline Other literature sources & - & - & ++ & ++ & ++ \\
\hline Empirical research data & - & - & ++ & - & Future research \\
\hline
\end{tabular}

Evaluation criteria: fulfilled (++), precise research questions, databases, search terms and synthesizing methods, are described. The literature findings are compared with other literature sources or empirical research data; not fulfilled (-), precise research questions, databases, search terms and synthesizing methods are not described. The literature findings are not compared with other literature sources or empirical research data

most important complexity driver's categories. As already mentioned, further research will be needed to create helpful advice for practitioners to detect complexity issues and to present methodological support to detect complexity causes and their effects.

Acknowledgements The authors would like to thank Professor Herbert Kotzab, the associate editor, and the anonymous reviewers for their detailed and constructive comments that significantly improved this study.

\section{Compliance with ethical standards}

Conflict of interest The authors declare that they have no conflict of interest.
Open Access This article is distributed under the terms of the Creative Commons Attribution 4.0 International License (http://crea tivecommons.org/licenses/by/4.0/), which permits unrestricted use, distribution, and reproduction in any medium, provided you give appropriate credit to the original author(s) and the source, provide a link to the Creative Commons license, and indicate if changes were made.

\section{Appendix}

See Tables 13, 14 and 15. 


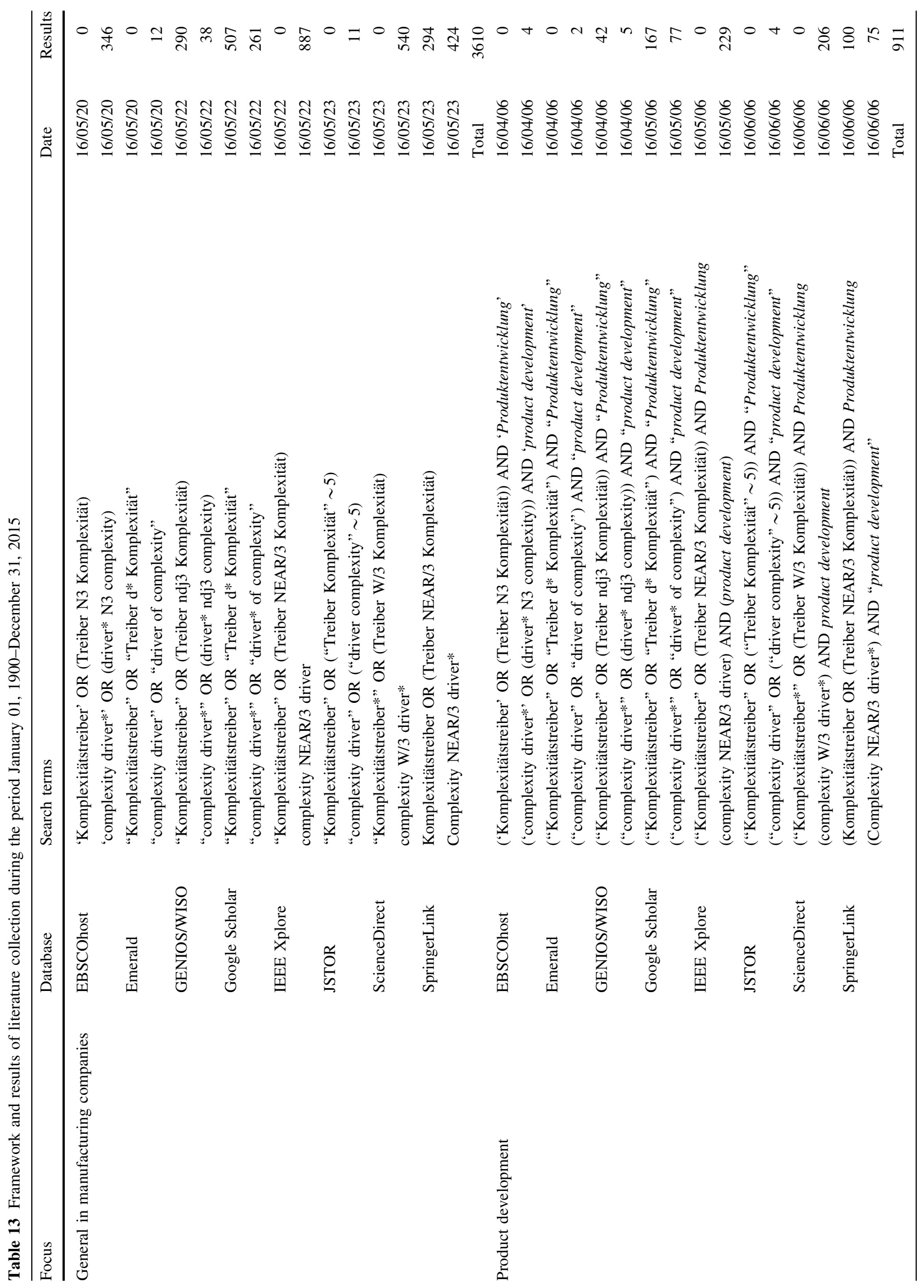




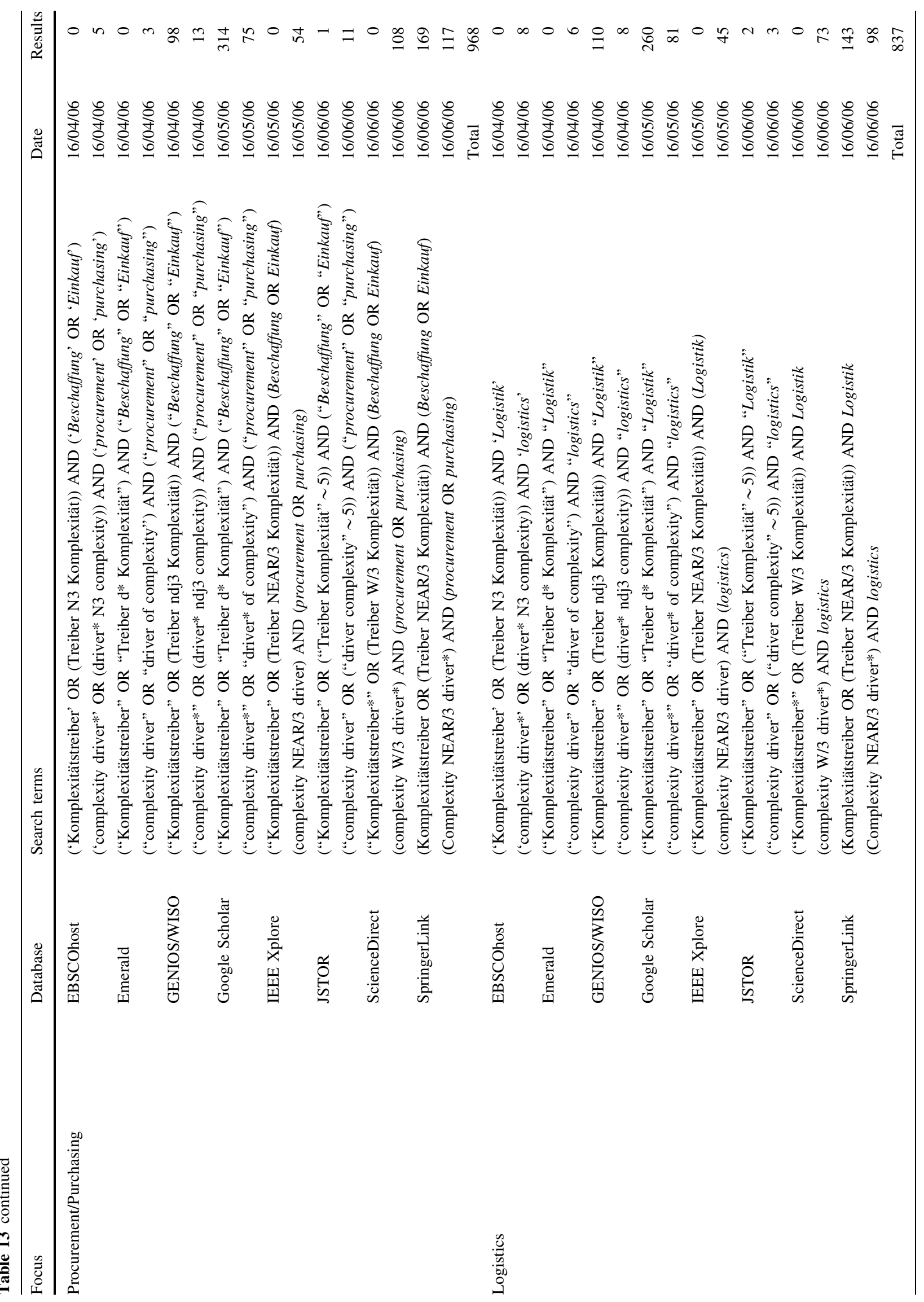




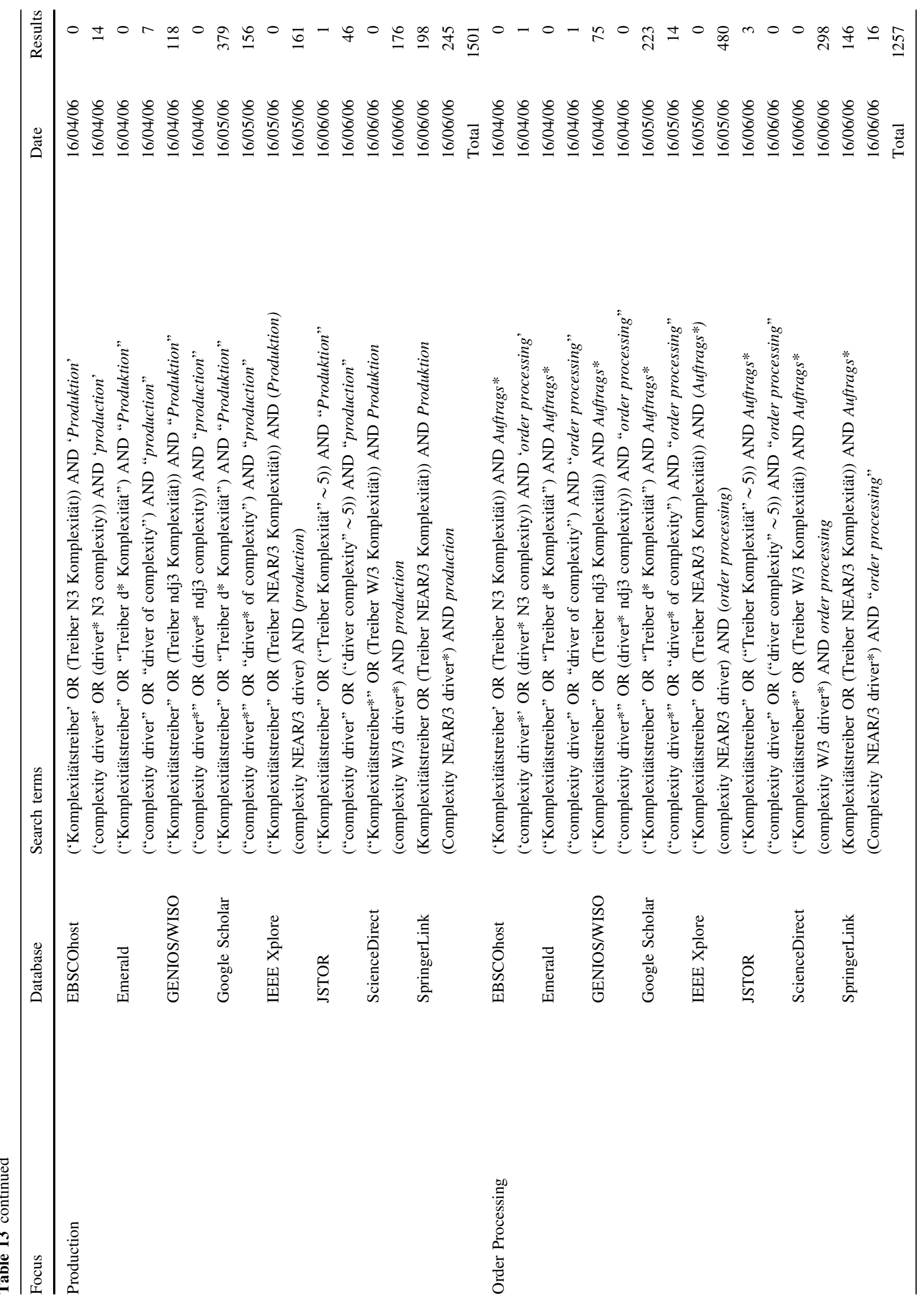




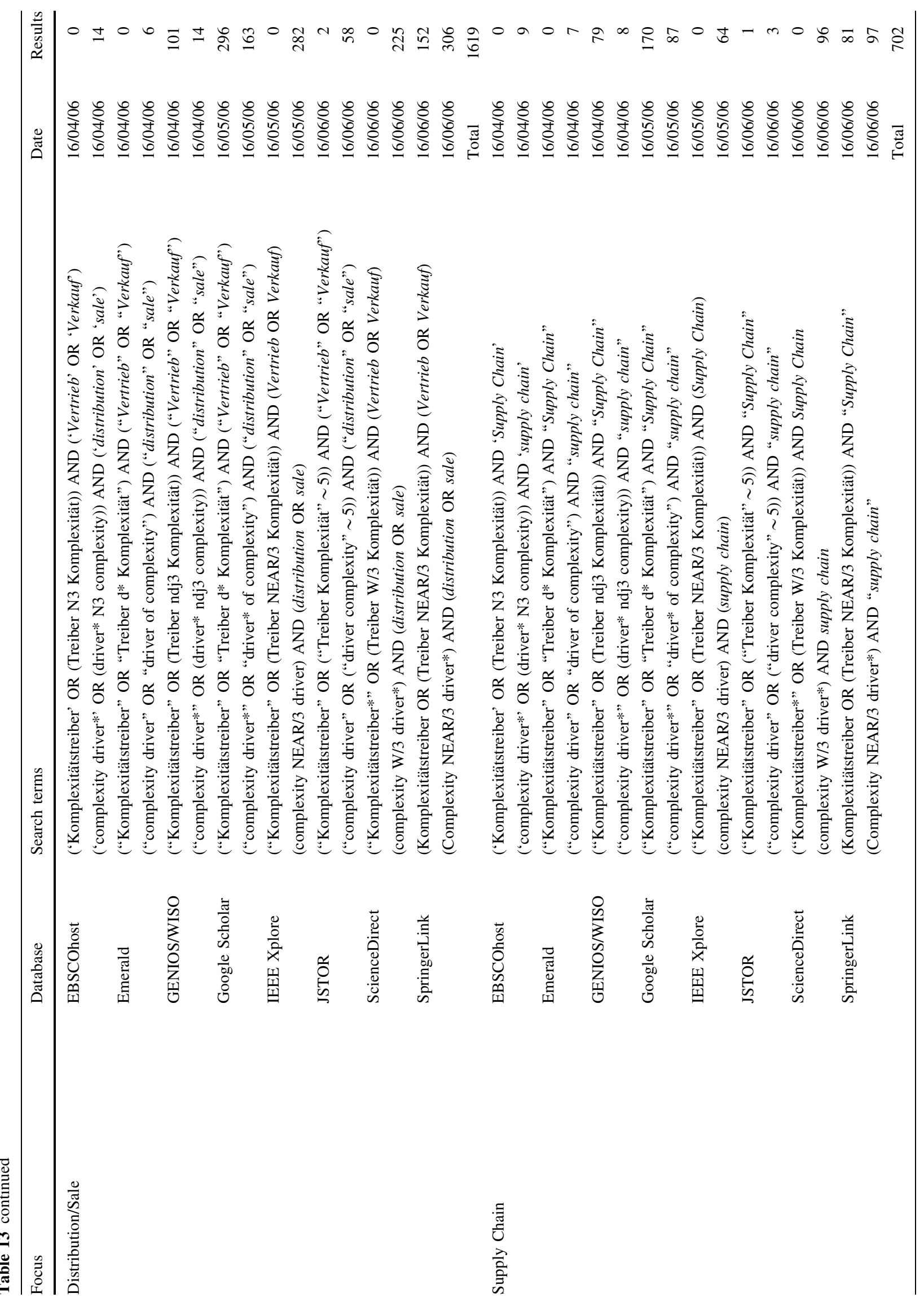




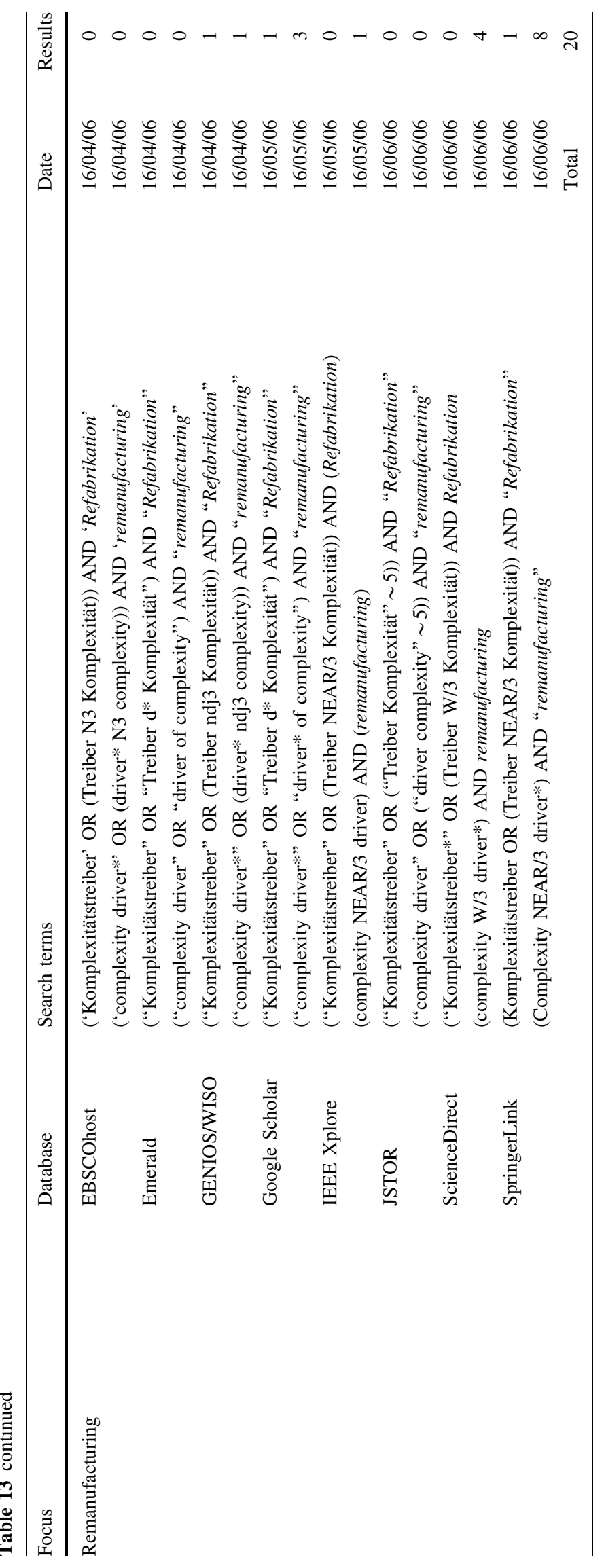




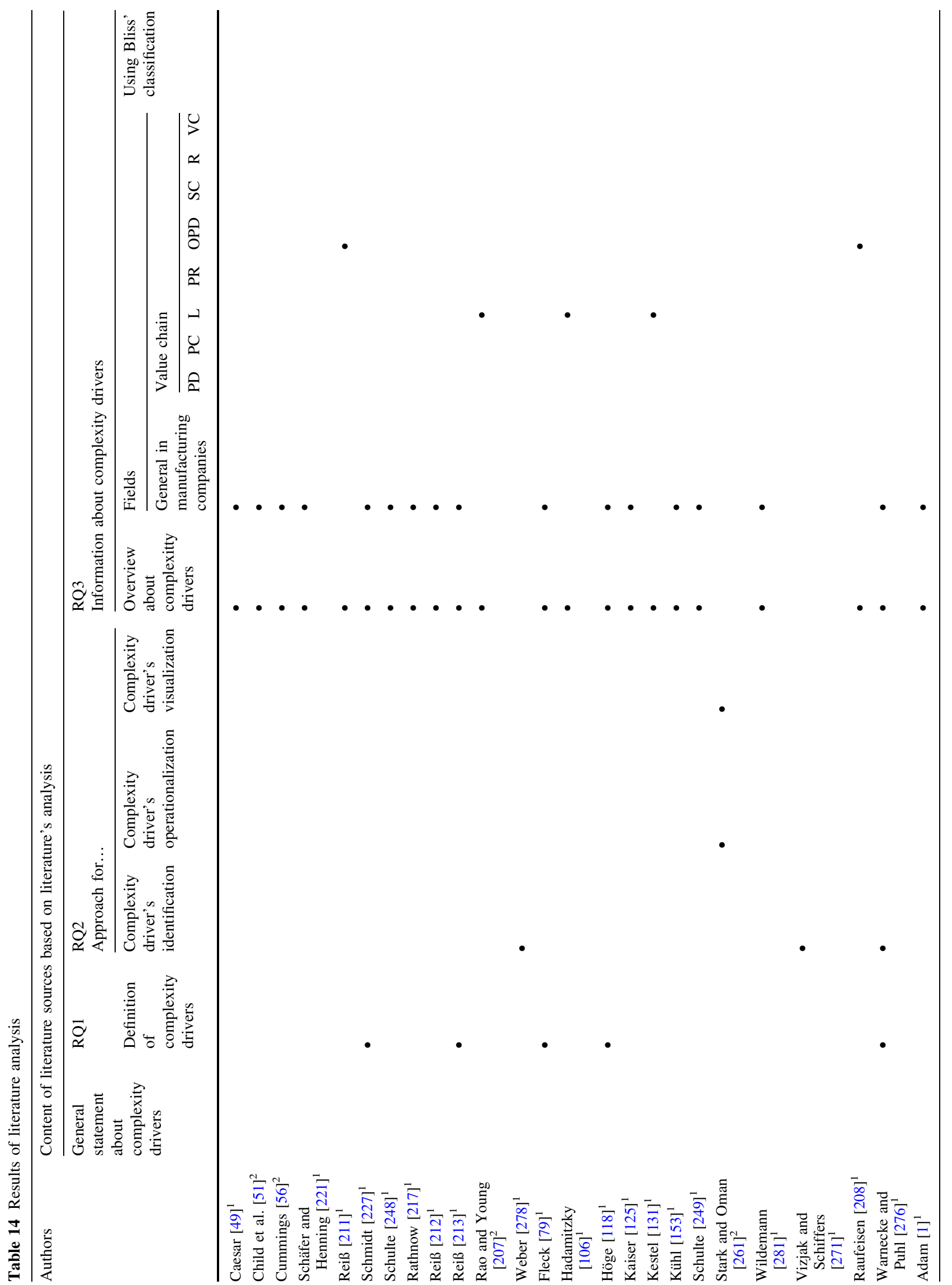




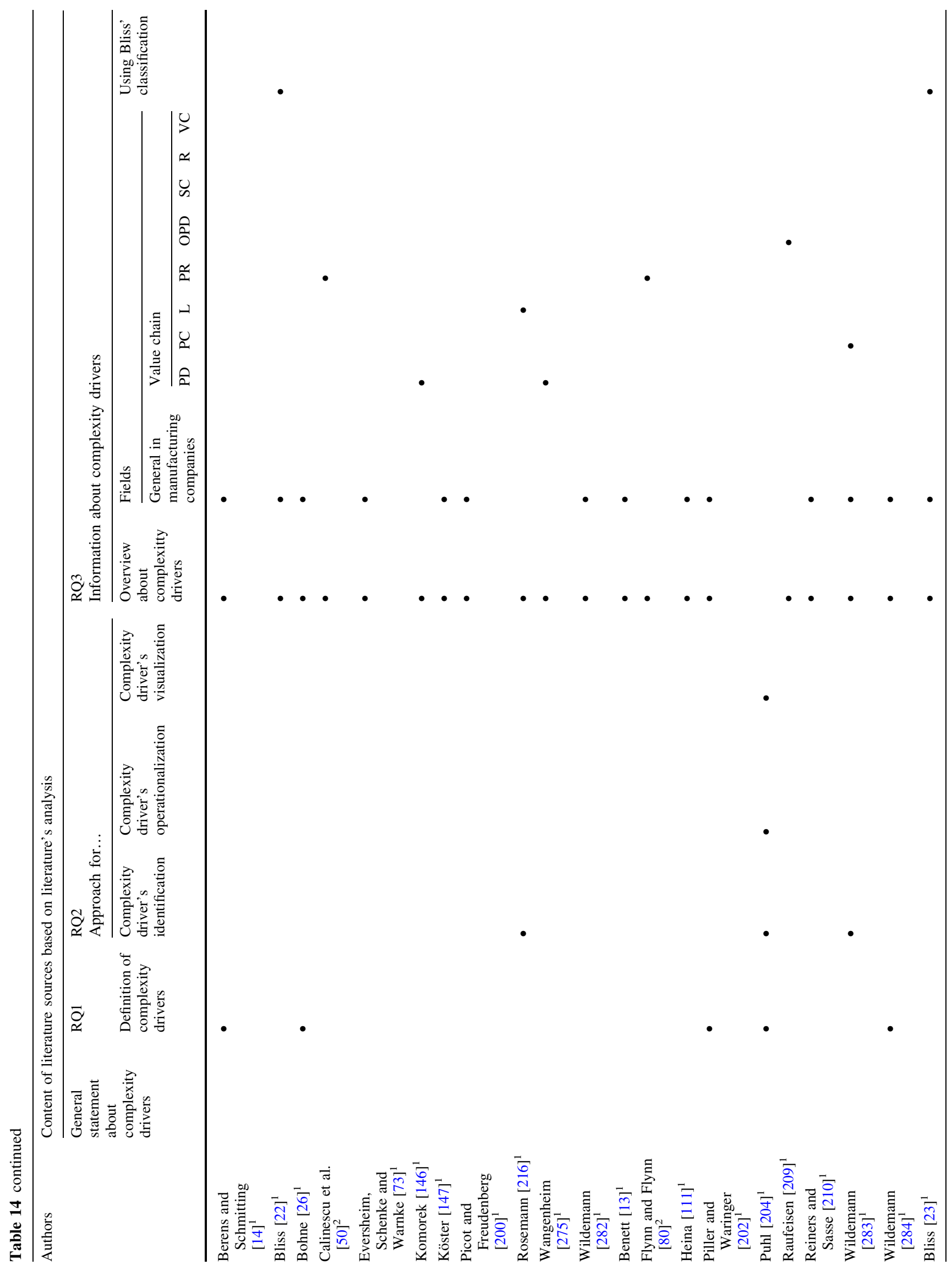




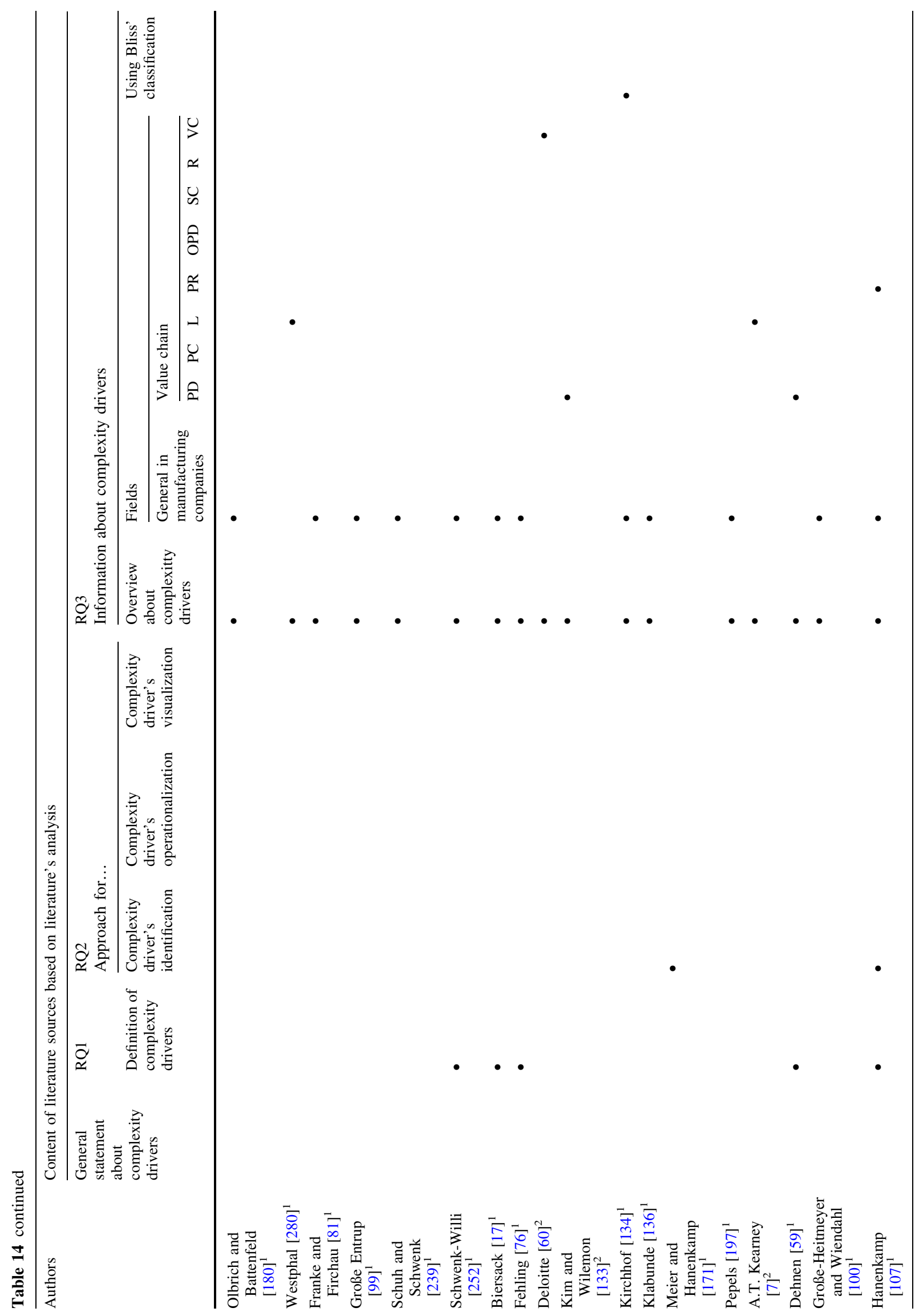




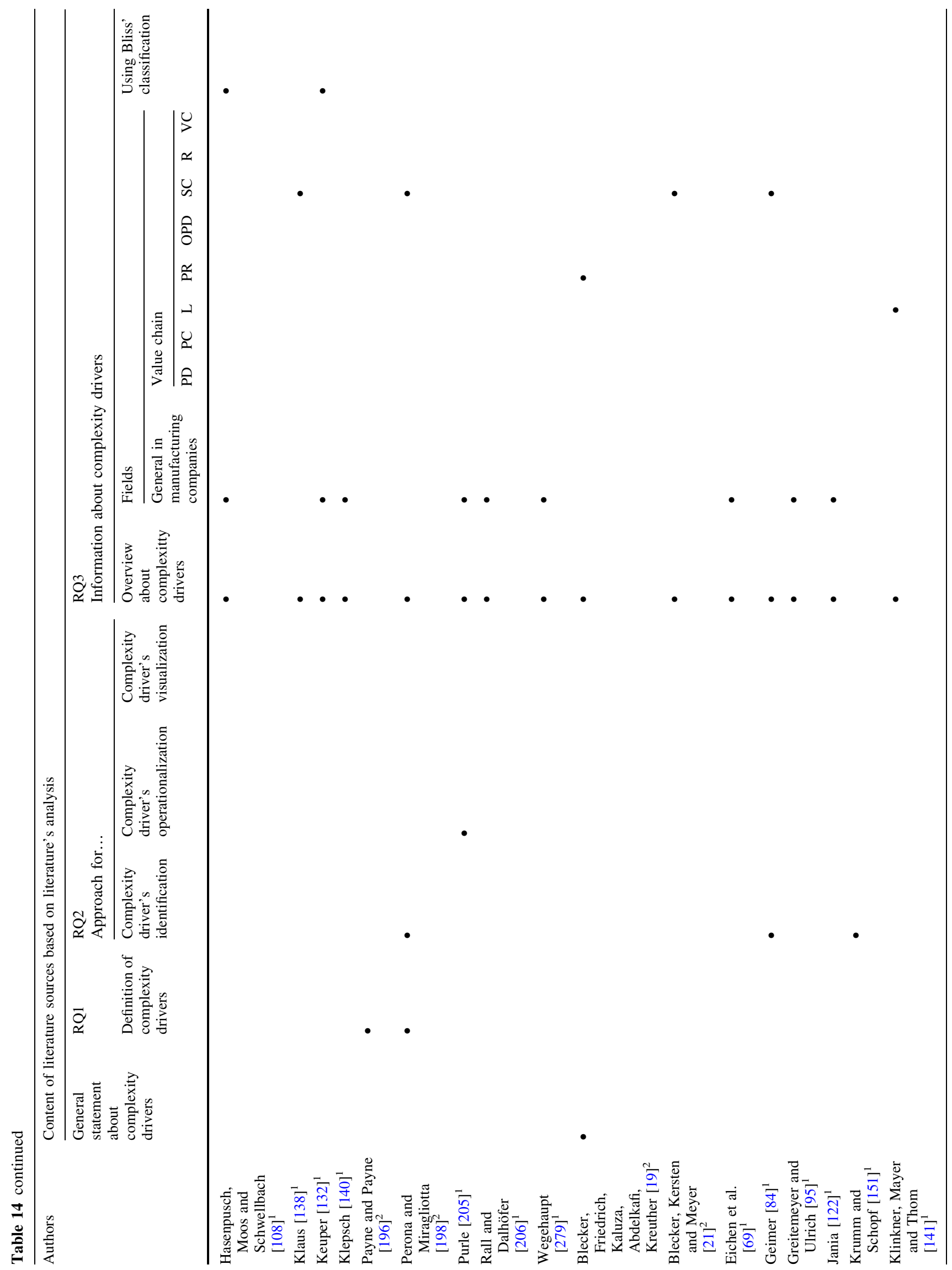




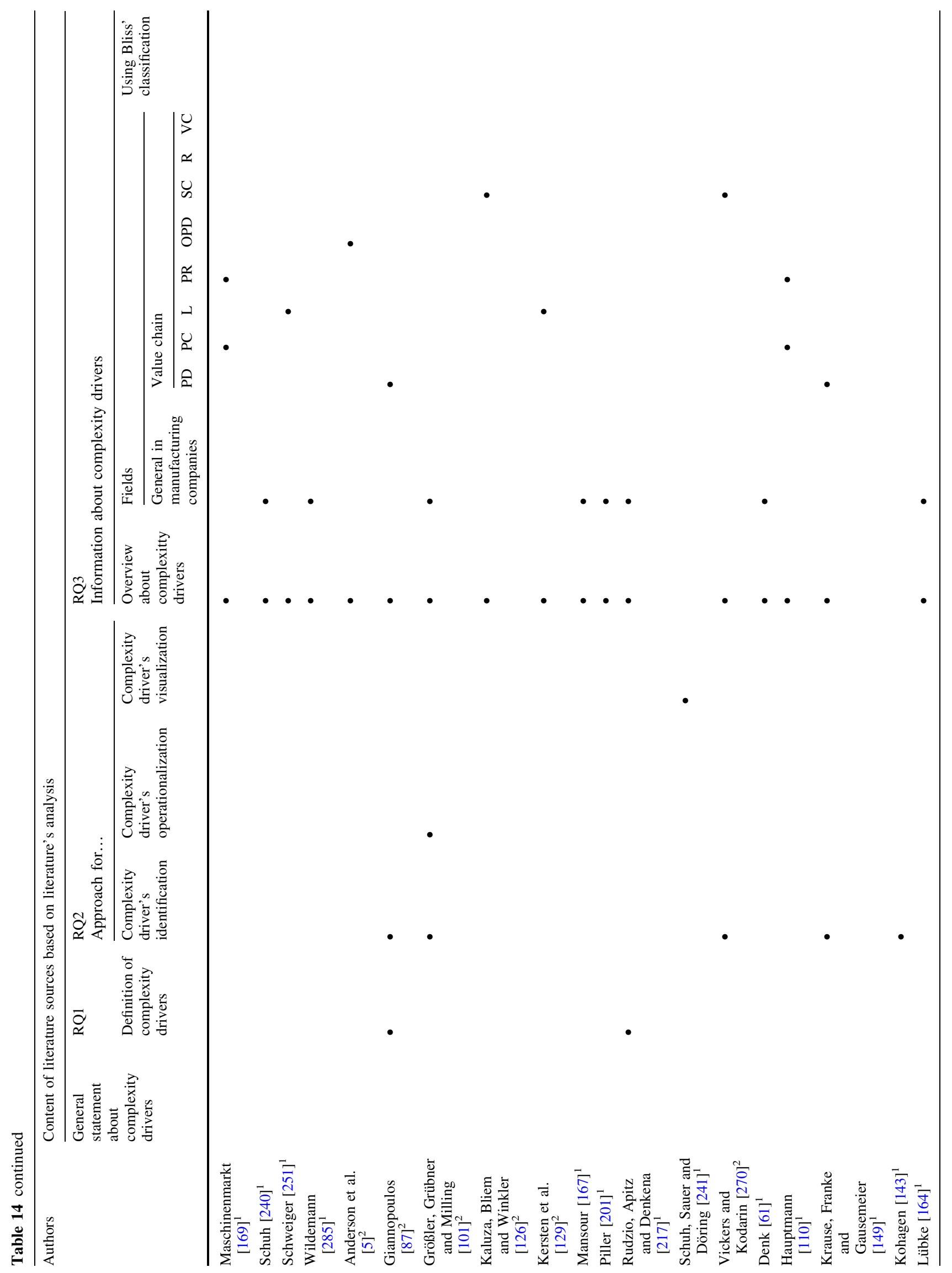




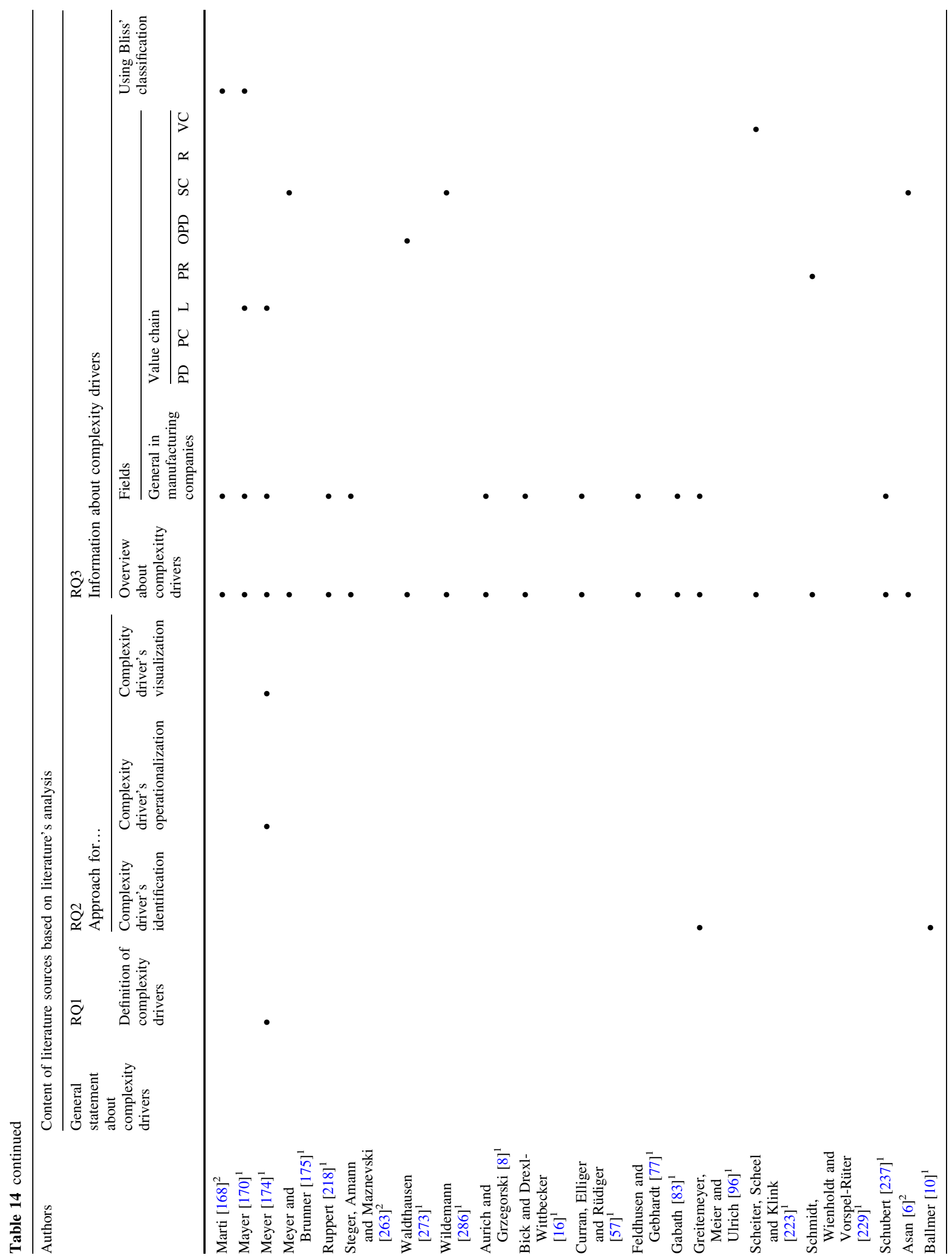




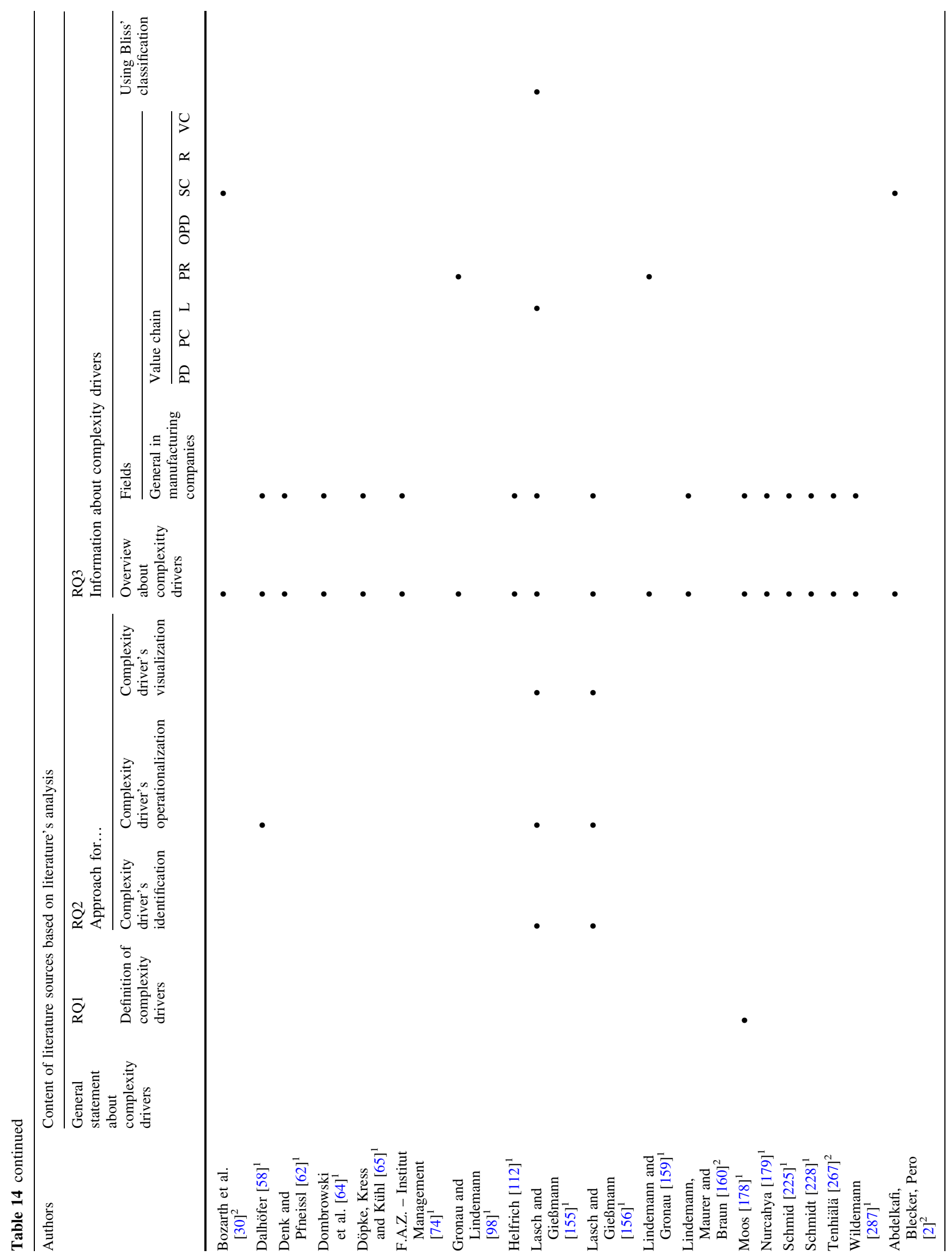




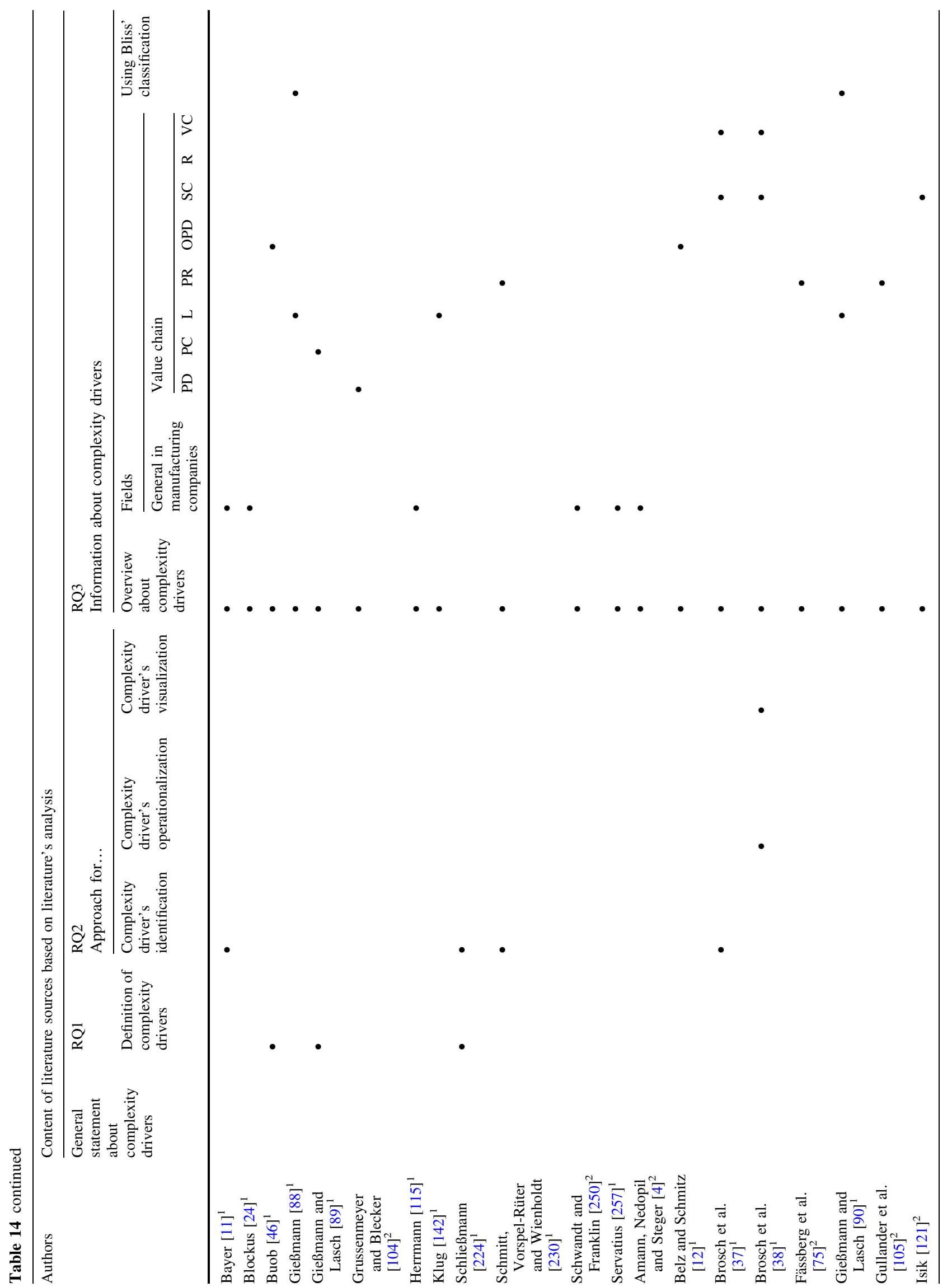




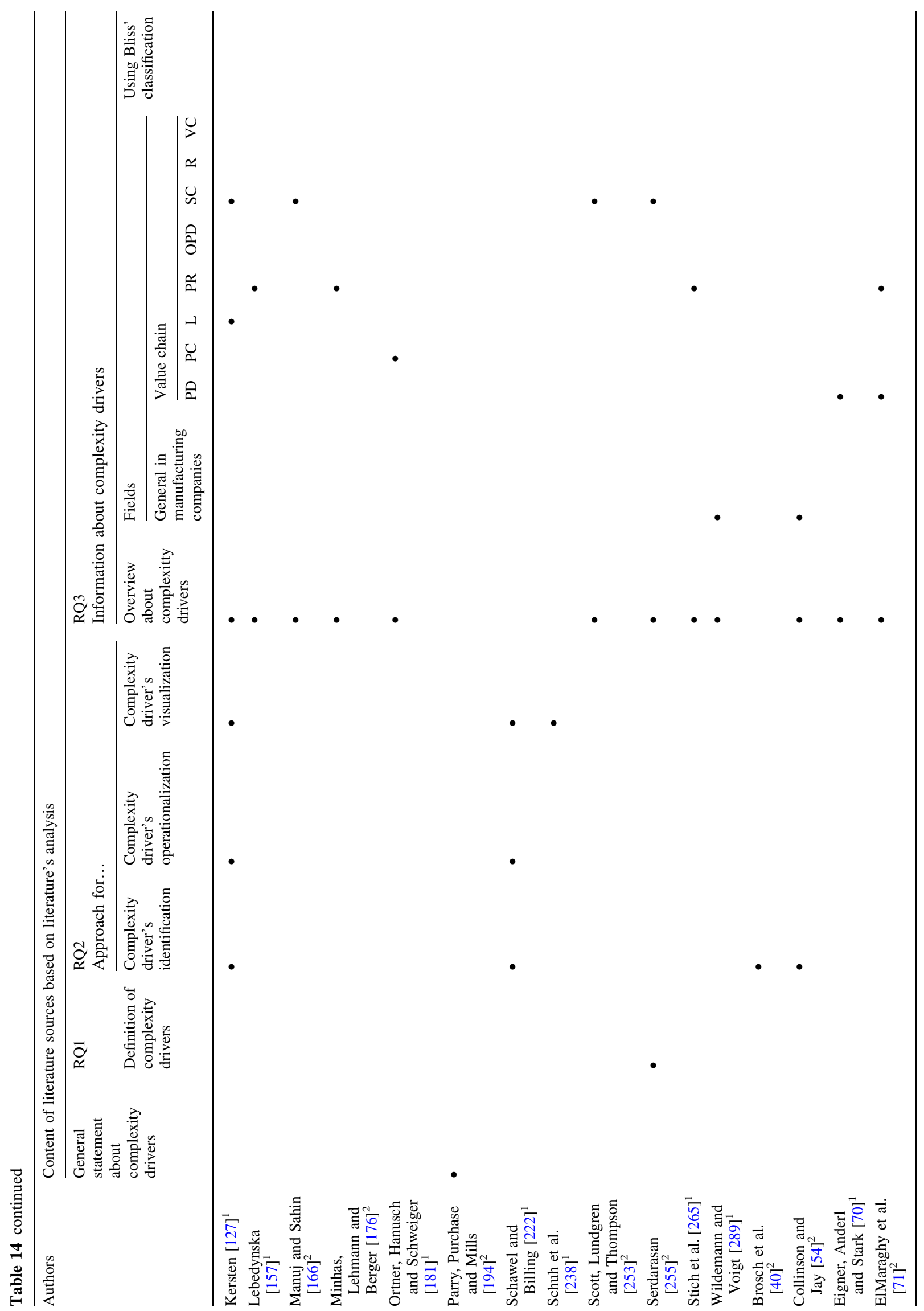




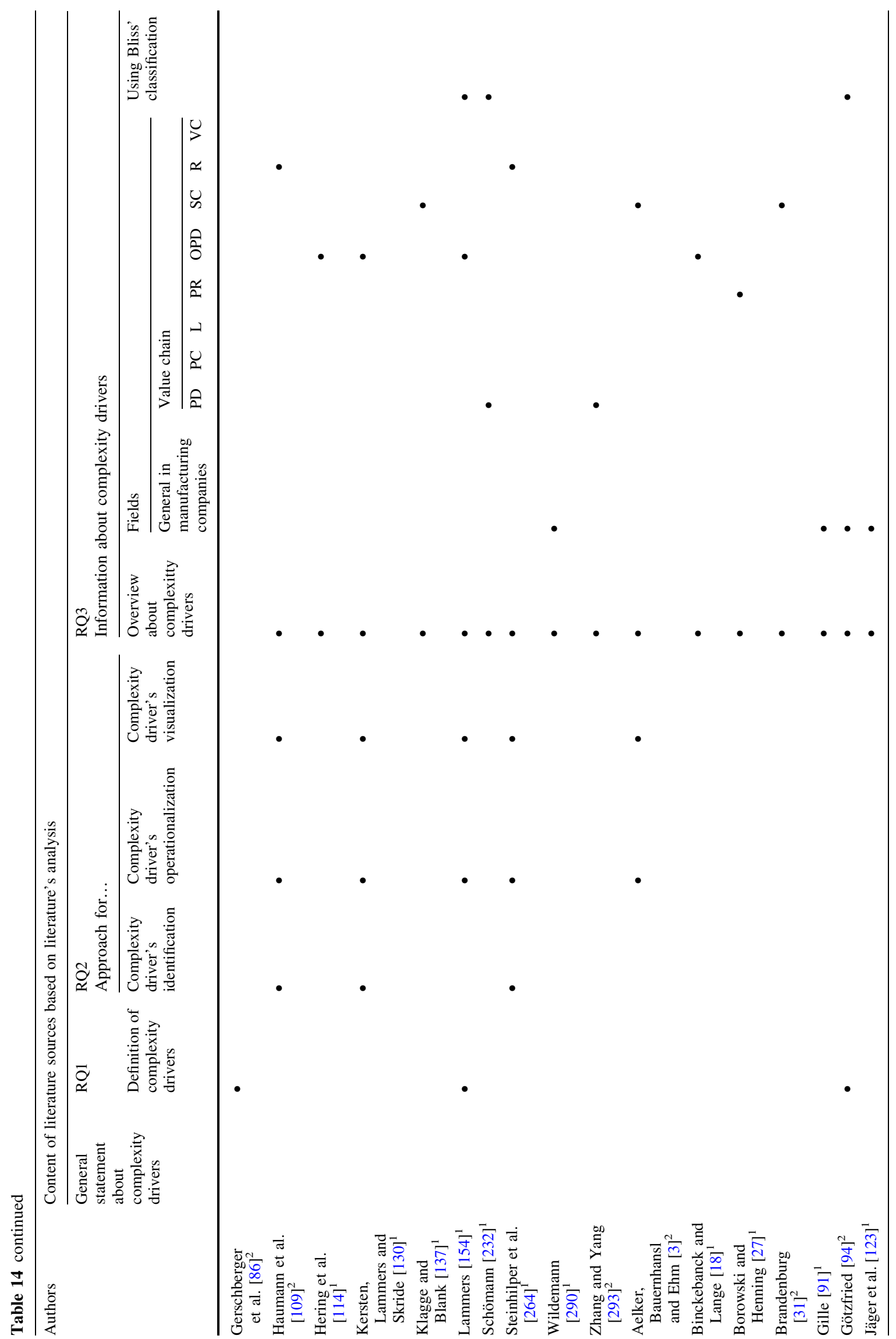




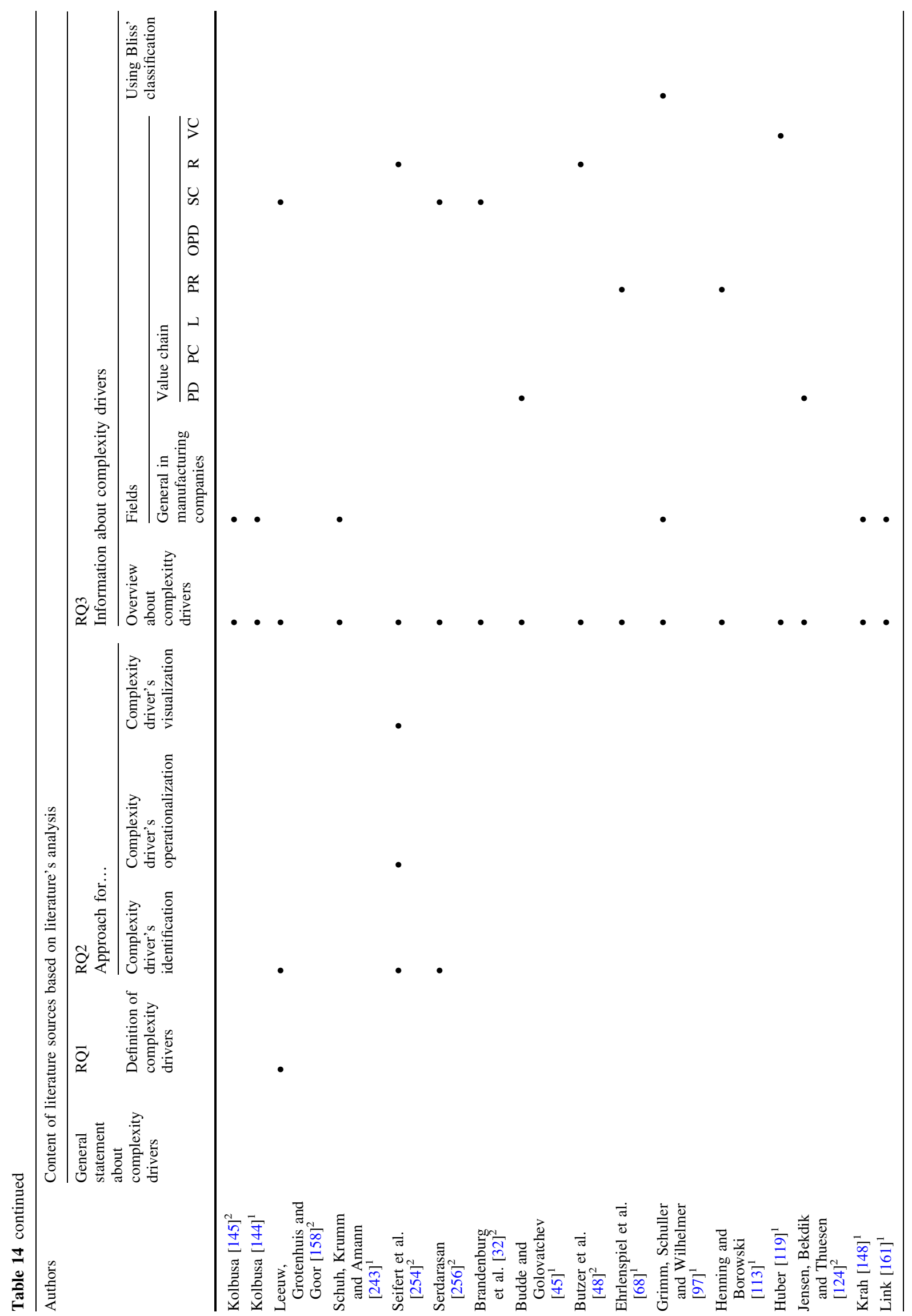




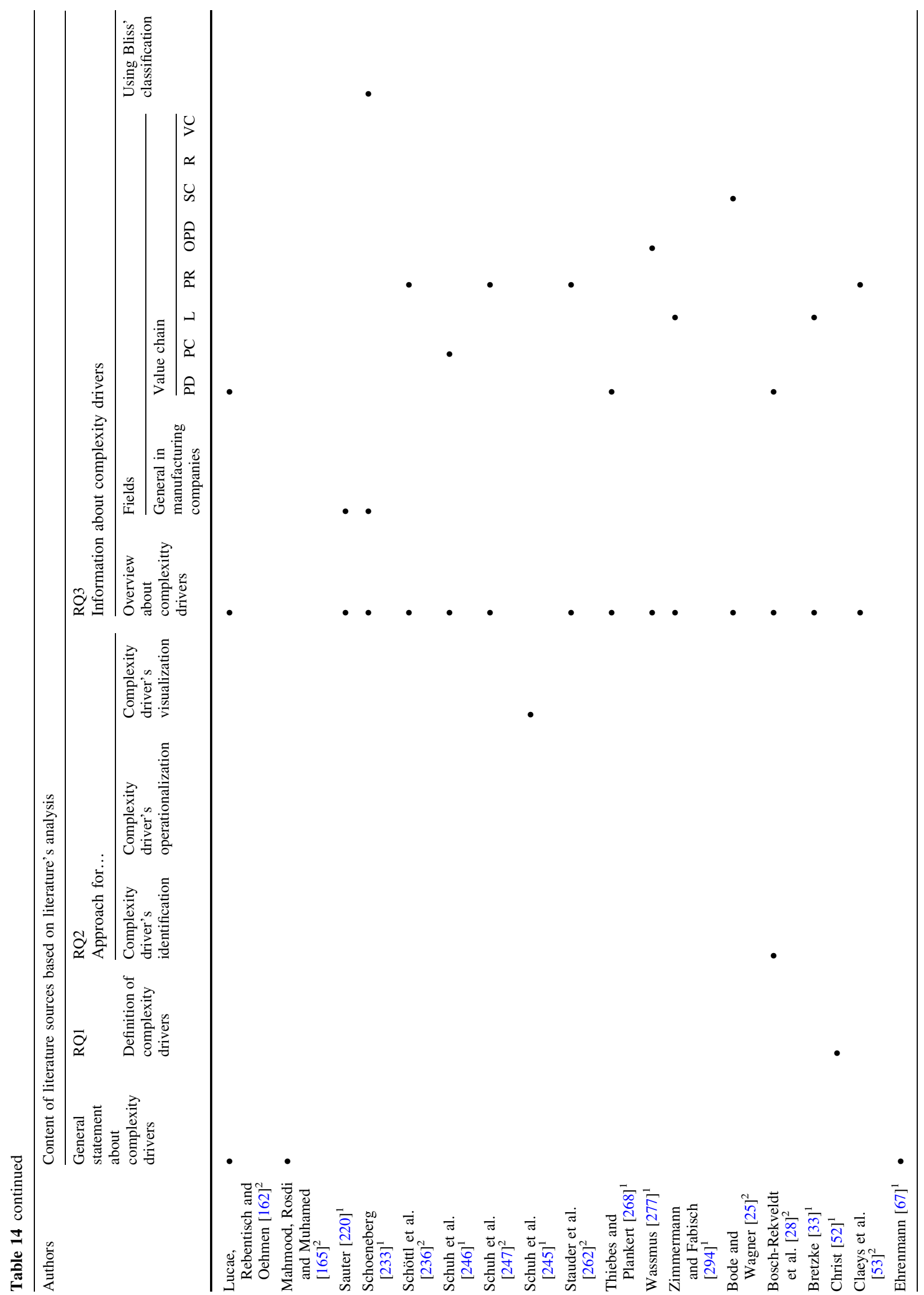




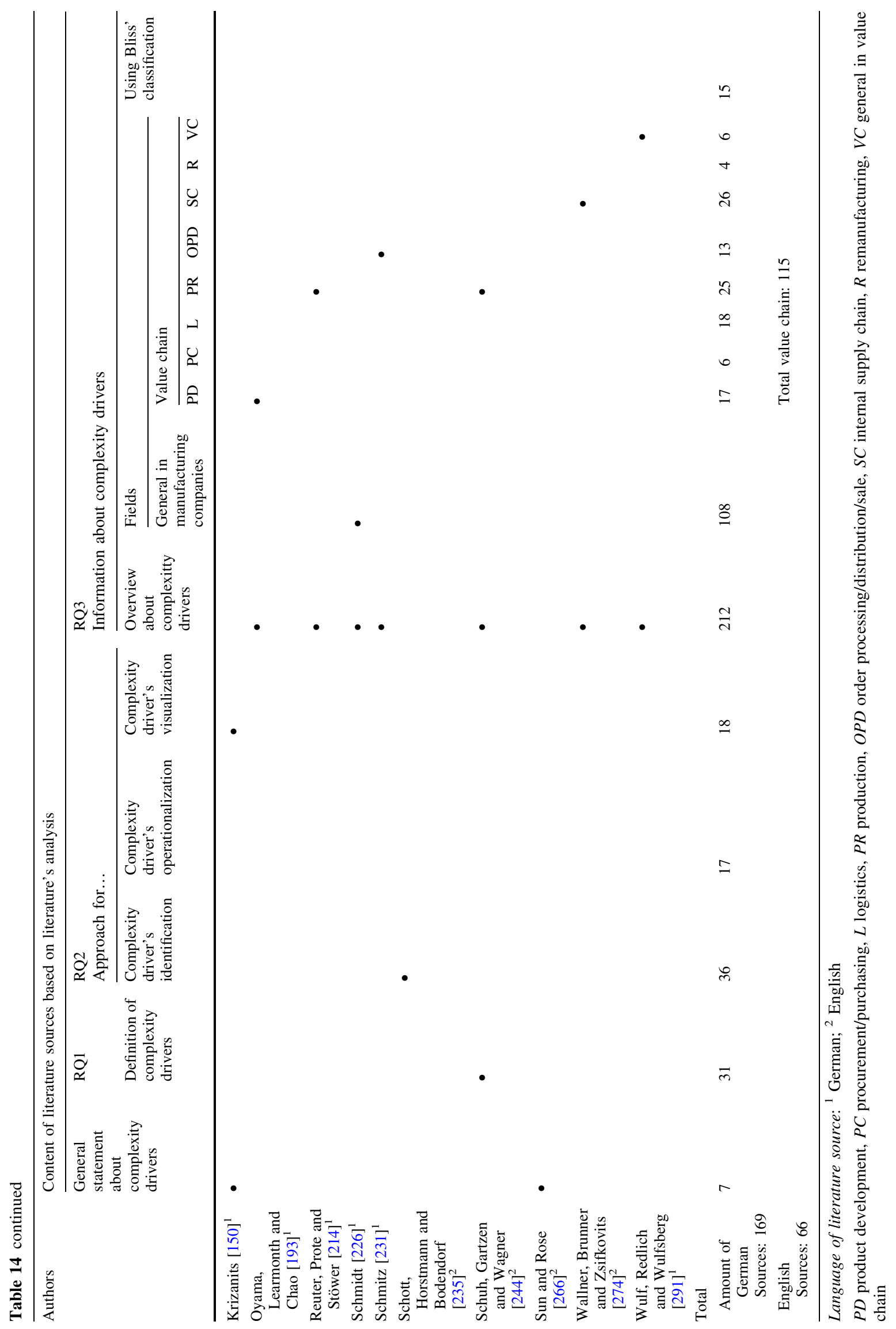




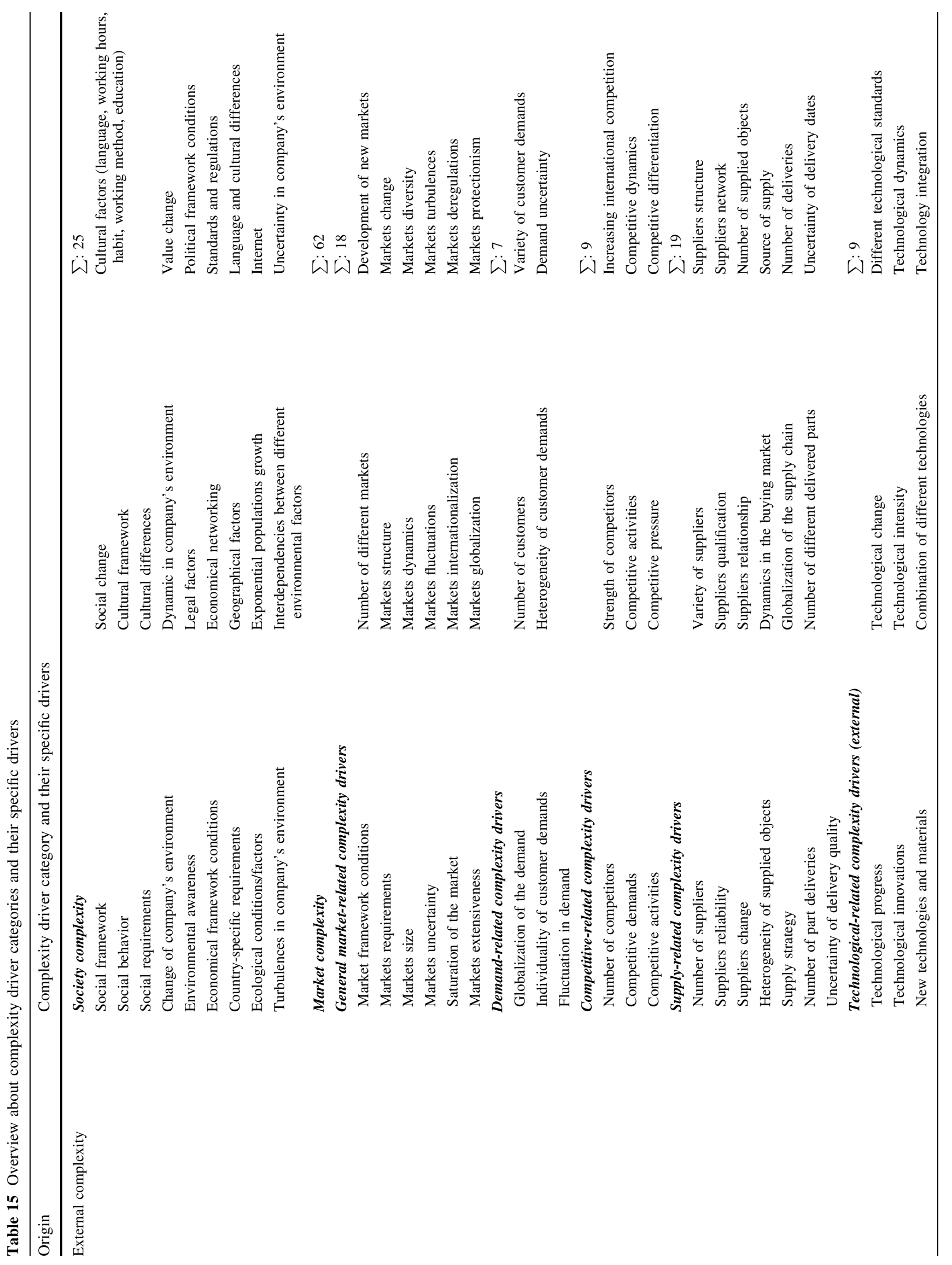



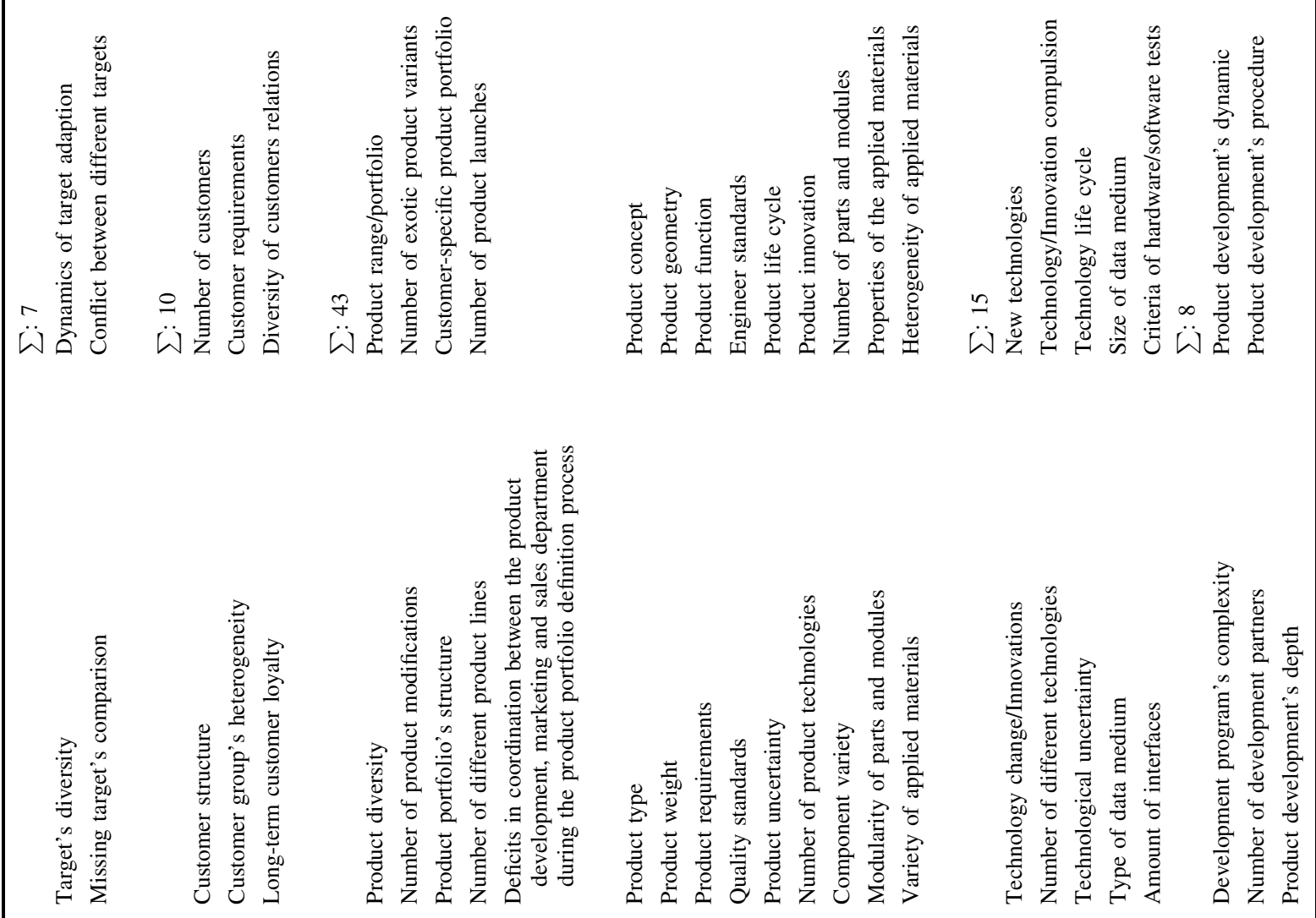


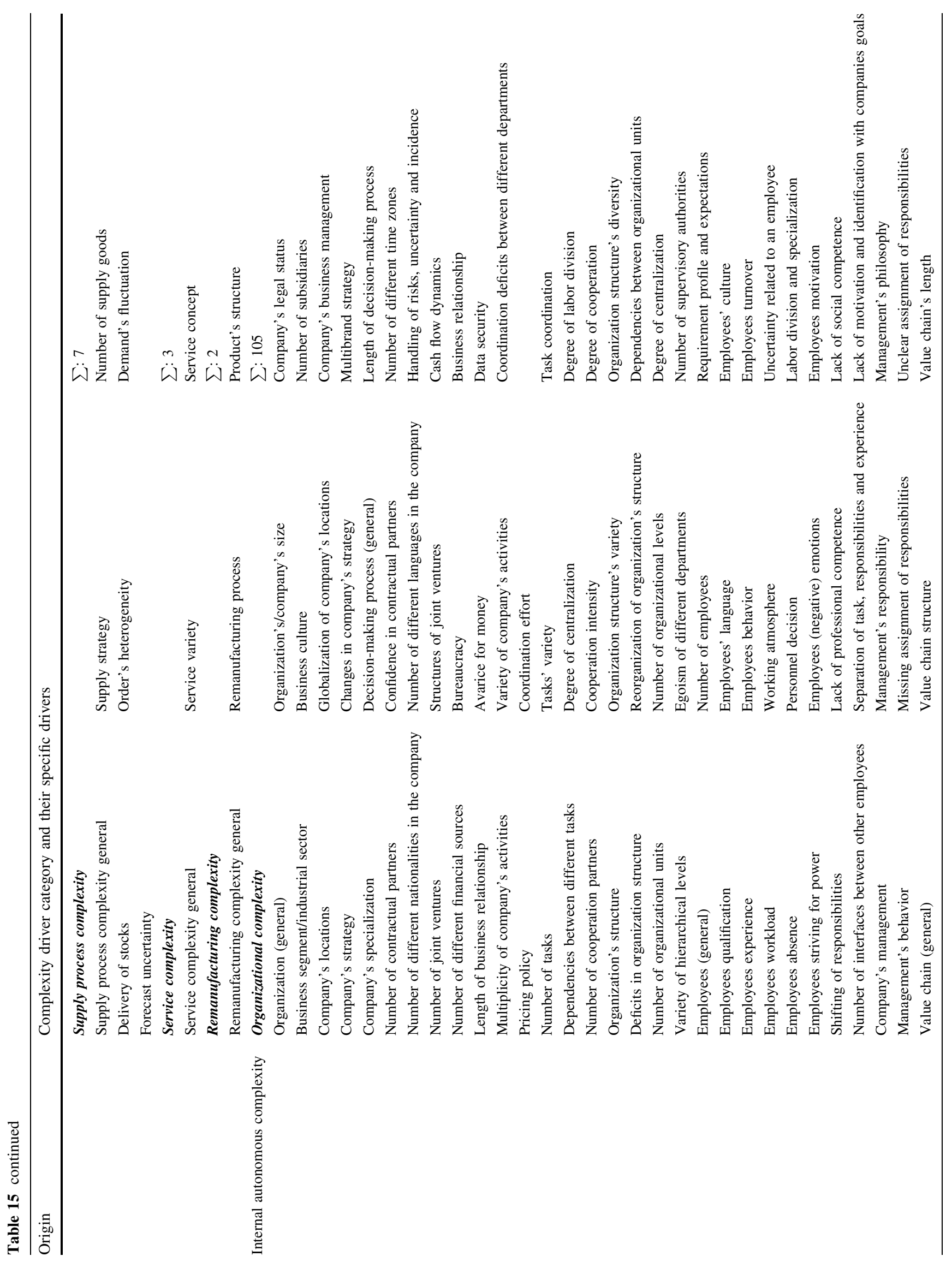



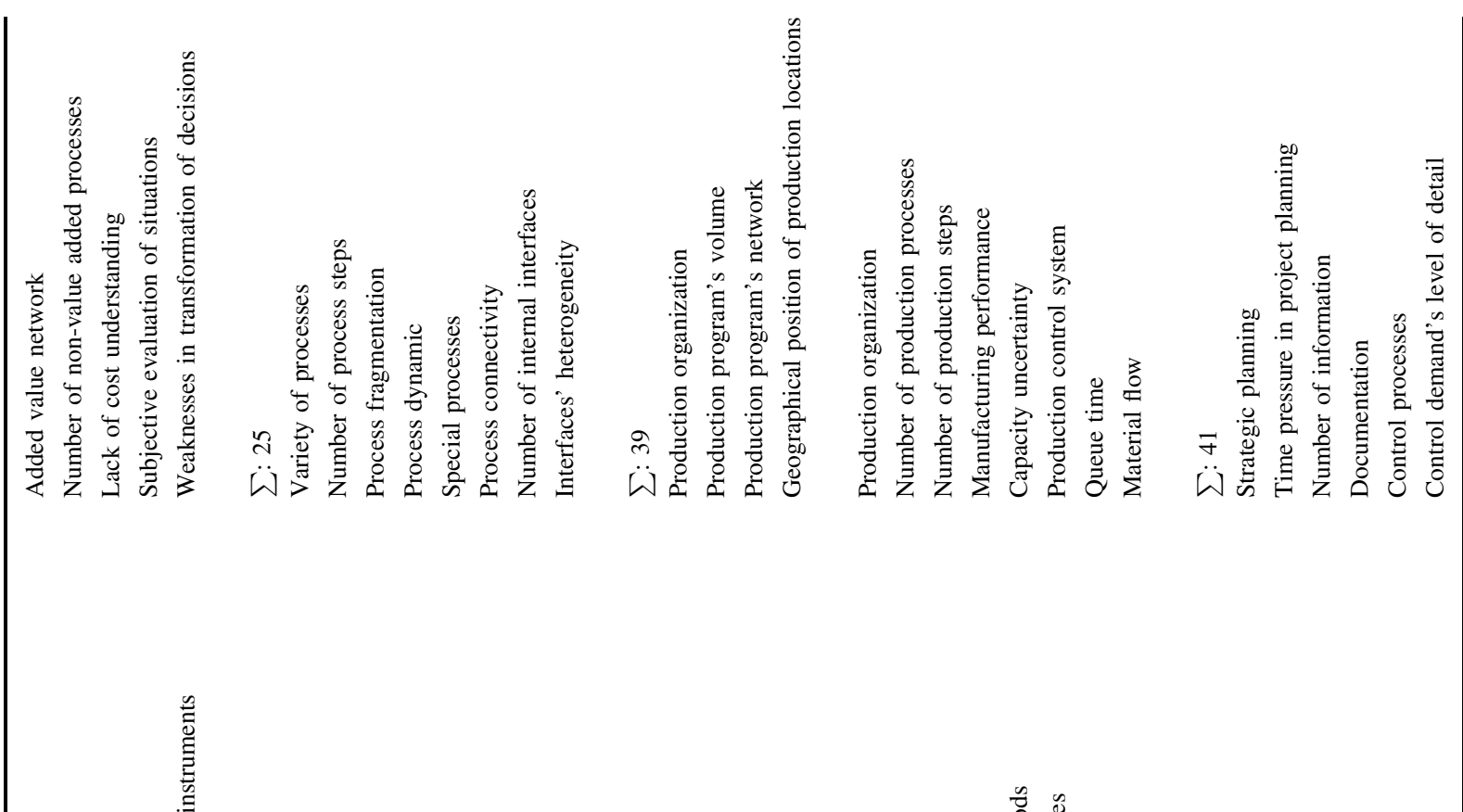

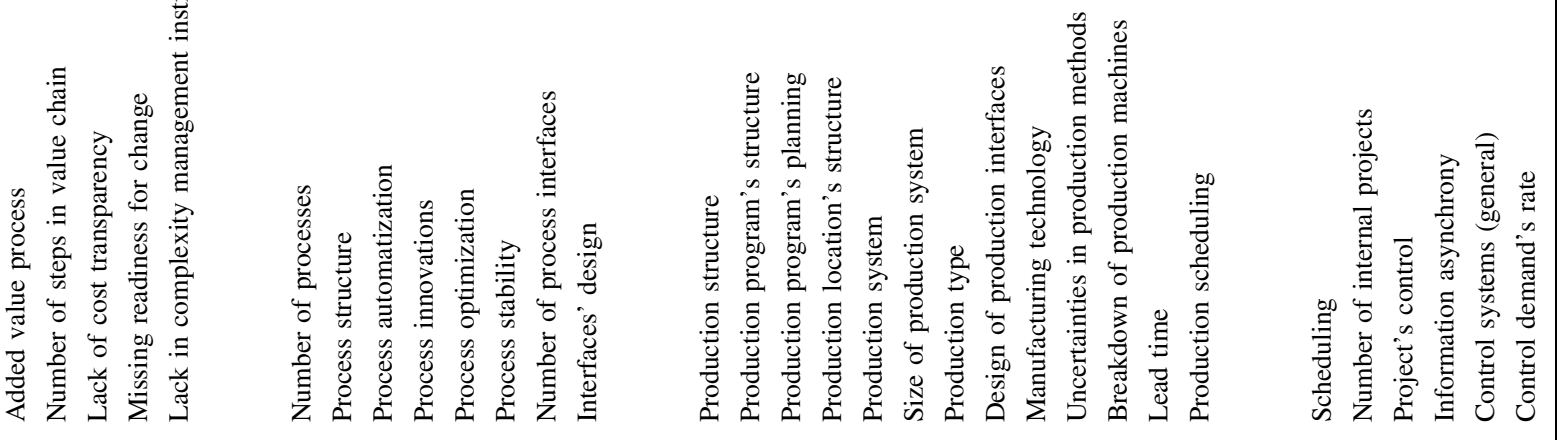

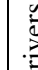

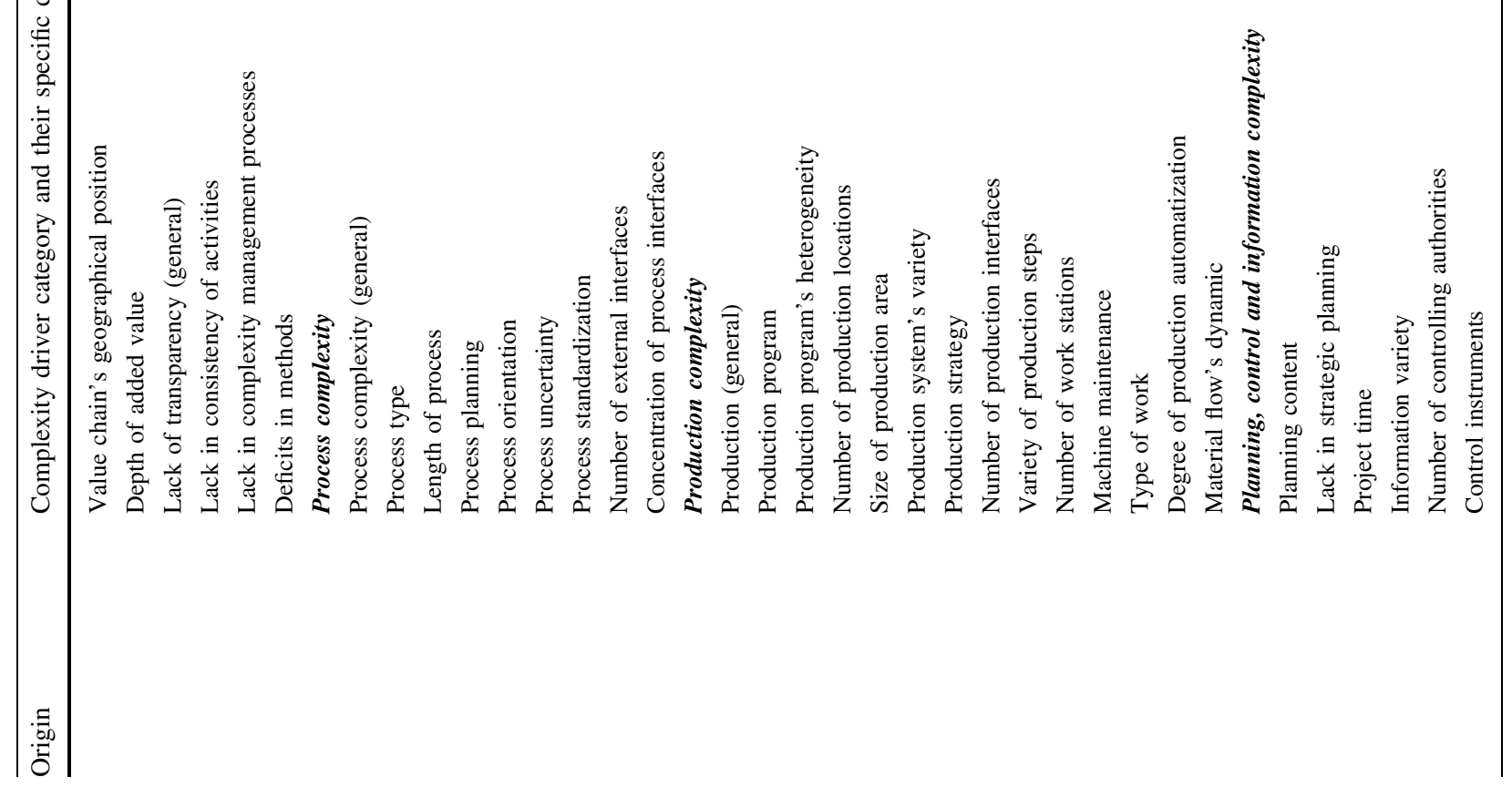




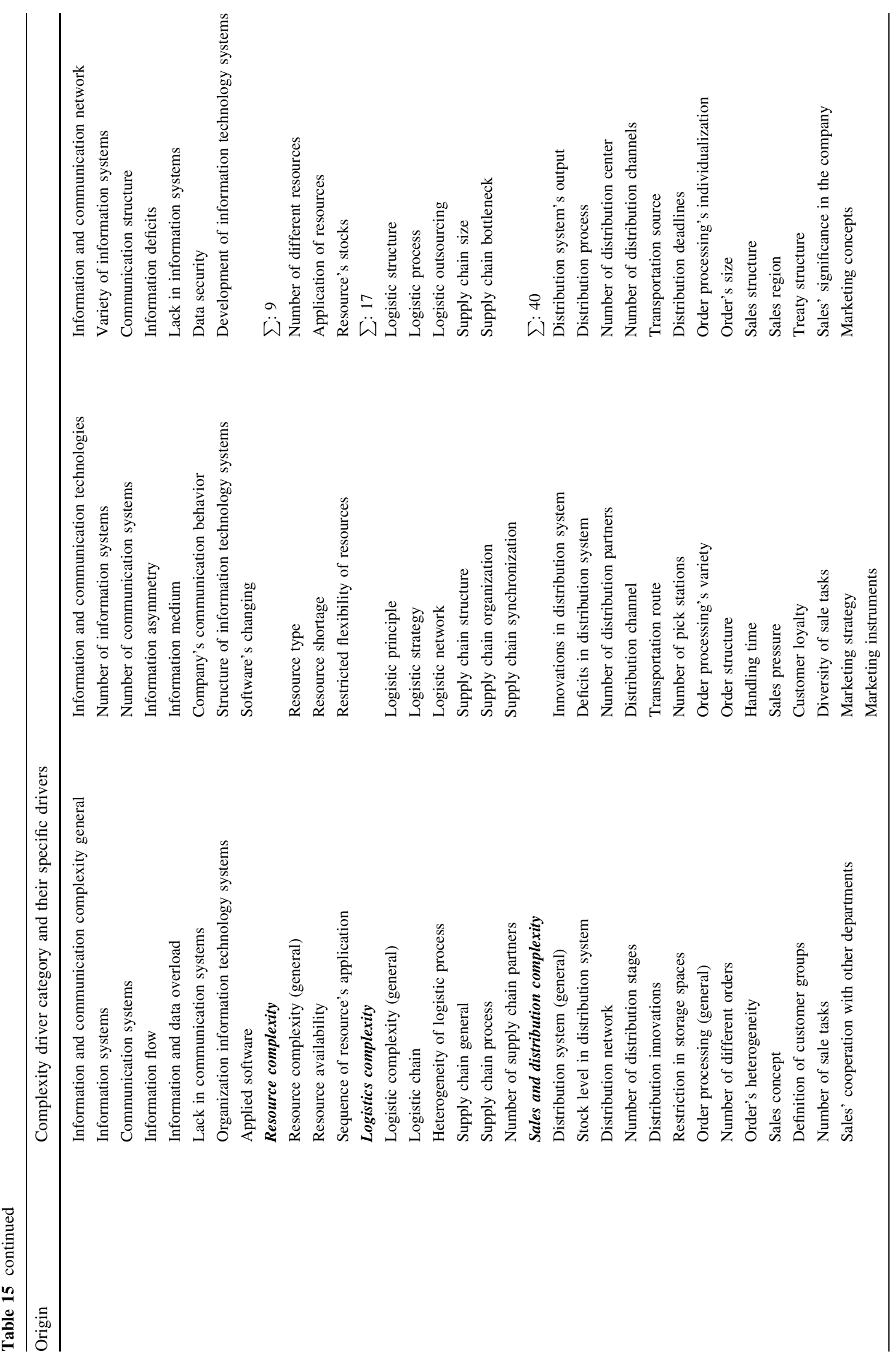




\section{References}

1. Adam D (1998) Produktions-management. Gabler, Wiesbaden

2. Abdelkafi N, Blecker T, Pero M (2010) Aligning new product development and supply chains: development of a theoretical framework and analysis of case studies. In: Huang G, Mak KL, Maropoulos PG (eds) Proceedings of the 6th CIRP-sponsored international conference on digital enterprise technology. Springer, Berlin, pp 1399-1419

3. Aelker J, Bauernhansl T, Ehm H (2013) Managing complexity in supply chains: a discussion of current approaches on the example of the semiconductor industry. Proc CIRP 7:79-84. doi:10.1016/j.procir.2013.05.014

4. Amann W, Nedopil C, Steger U (2011) The meta-challenge of complexity for global companies. Database Mark Cust Strategy Manag 18(3):200-204. doi:10.1057/dbm.2011.21

5. Anderson B, Hagen C, Reifel J, Stettler E (2006) Complexity: customization's evil twin. Strategy Leadersh 34(5):19-27. doi: $10.1108 / 10878570610684801$

6. Asan S (2009) A methodology based on theory of constraints' thinking processes for managing complexity in the supply chain. Dissertation, Technical University of Berlin

7. A.T. Kearney (2004) The complexity challenge: a survey on complexity management across the supply chain. A.T. Kearney. http://atkearneyprocurementsolutions.com/knowledge/publica tions/2004/Complexity_Management_S.pdf. Accessed 20 May 2015

8. Aurich J, Grzegorski A (2008) Vielfaltsinduzierte Komplexität in Ingenieurprozessen: gestaltung, Beherrschung und Verbesserung komplexer Ingenieurprozesse in Netzwerken global verteilter Entwicklungs- und Produktionsstandorte. ZWF Z Wirtsch Fabrikbetr 103(5):316-321

9. Backhaus K, Erichson B, Plinke W, Weiber R (2011) Multivariate Analysemethoden: Eine anwendungsorientierte Einführung, 13th edn. Springer, Heidelberg

10. Ballmer R (2009) Die Dynamik der Nachfrage meistern. Handelszeitung, 13 May, p 61

11. Bayer $\mathrm{T}$ (2010) Integriertes Variantenmanagement: Variantenkostenbewertung mit faktoranalytischen Komplexitätstreibern. Rainer Hampp, München

12. Belz C, Schmitz C (2011) Verkaufskomplexität: Leistungsfähigkeit des Unternehmens in die Interaktion mit dem Kunden übertragen. In: Homburg C, Wiesecke J (eds) Handbuch Vertriebsmanagement: Strategie, Führung, Informationsmanagement, CRM. Gabler, Wiesbaden, pp 181-206

13. Benett S (1999) Komplexitätsmanagement in der Investitionsgüterindustrie. Difo, Bamberg

14. Berens W, Schmitting W (1998) Controllinginstrumente für das Komplexitätsmanagement: Potentiale des internen Rechnungswesen. In: Adam D (ed) Komplexitätsmanagement. Gabler, Wiesbaden, pp 67-110

15. van Bertalanffy L (1950) An outline of general system theory. Br J Philos Sci 1(2):134-165. doi:10.1093/bjps/I.2.134

16. Bick W, Drexl-Wittbecker S (2008) Komplexität reduzieren: Konzept, Methode, Praxis. LOG_X, Stuttgart

17. Biersack F (2002) Gestaltung und Nutzung makrostruktureller Flexibilität. Europäischer Verlag der Wissenschaft, Frankfurt am Main

18. Binckebanck L, Lange J (2013) Komplexitätsmanagement als Führungsaufgabe im Vertrieb. In: Binckebanck L, Hölter A-K, Tiffert A (eds) Führung von Vertriebsorganisationen: Strategie Koordination - Umsetzung. Springer Gabler, Wiesbaden, pp 91-114

19. Blecker T, Friedrich G, Kaluza B, Abdelkafi N, Kreutler G (2005) Information and management systems for product customization. Springer, Boston 
20. Blecker T, Kersten W (2006) Complexity management in supply chains: concepts, tools and methods. Erich Schmidt, Berlin

21. Blecker T, Kersten W, Meyer C (2005) Development of an approach for analyzing supply chain complexity. Hamburg University of Technology. http://mpra.ub.uni-muenchen.de/ 5284/1/MPRA_paper_5284.pdf. Accessed 20 May 2015

22. Bliss C (1998) Komplexitätsreduktion und Komplexitätsbeherrschung bei der Schmitz-Anhänger Fahrzeugbau- Gesellschaft mbH. In: Adam D (ed) Komplexitätsmanagement. Gabler, Wiesbaden, pp 145-168

23. Bliss C (2000) Management von Komplexität - Ein integrierter, systemtheoretischer Ansatz zur Komplexitätsreduktion. Betriebswirtschaftlicher Verlag, Wiesbaden

24. Blockus M-O (2010) Komplexität in Dienstleistungsunternehmen: Komplexitätsformen, Kosten- und Nutzenwirkungen, empirische Befunde und Managementimplikationen. Gabler, Wiesbaden

25. Bode C, Wagner SM (2015) Structural drivers of upstream supply chain complexity and the frequency of supply chain disruptions. J Oper Manag 36:15-228. doi:10.1016/j.jom.2014. 12.004

26. Bohne F (1998) Komplexitätskostenmanagement in der Automobilindustrie: Identifizierung und Gestaltung vielfaltsinduzierter Kosten. Gabler, Wiesbaden

27. Borowski E, Henning K (2013) Agile Prozessgestaltung und Erfolgsfaktoren im Produktionsanlauf als komplexer Prozess. In: Jeschke S, Isenhardt I, Hees F, Henning K (eds) Automation, communication and cybernetics in science and engineering 2011/2012. Springer, Berlin, pp 27-40

28. Bosch-Rekveldt M, Bakker H, Hertogh M, Mooi H (2015) Drivers of complexity in engineering projects. In: Schwindt C, Zimmermann J (eds) Handbook on project management and scheduling, vol 2. Springer, Cham, pp 1079-1104. doi:10.1007/ 978-3-319-05915-0_18

29. Boyksen M, Kotlik L (2013) Komplexitätscontrolling: Komplexität erkennen, bewerten und optimieren. Controll. Mag. http://www.camelot-mc.com/fileadmin/user_upload/Presse/2013/ Controller_Magazin_Komplexitaetscontrolling.pdf. Accessed 20 May 2015

30. Bozarth C, Warsing D, Flynn B, Flynn J (2009) The impact of supply chain complexity on manufacturing plant performance. J Oper Manag 27:78-93. doi:10.1016/j.jom.2008.07.003

31. Brandenburg M (2013) Quantitative models for value-based supply chain management. Springer, Heidelberg

32. Brandenburg M, Kuhn H, Schilling R, Seuring S (2014) Performance- and value-oriented decision support for supply chain configuration: a discrete-event simulation model and a case study of an FMCG manufacturer. Logist Res 7(118):1-16. doi:10.1007/s12159-014-0118-8

33. Bretzke W-R (2015) Logistiche Netzwerke, 3rd edn. Springer Vieweg, Berlin. doi:10.1007/978-3-662-47921-6_1

34. Brewerton P, Millward L (2001) Organizational research methods. Sage, London

35. Brockhaus (2006) Enzyklopädie in 30 Bänden: Band 6 ComfDiet. Brockhaus, Leipzig

36. Bronner R (1992) Komplexität. In: Frese E (ed) Enzyklopädie der Betriebswirtschaftslehre: Handwörterbuch der Organisation. Poeschel, Stuttgart, pp 1121-1130

37. Brosch M, Beckmann G, Griesbach M, Dalhöfer J, Krause D (2011) Design for Value Chain: Ausrichtung des Komplexitätsmanagements auf globale Wertschöpfungskette. ZWF Z Wirtsch Fabrikbetr 106(11):855-860

38. Brosch M, Beckmann G, Krause D, Griesbach M, Dalhöfer J (2011) Design for Value Chain - Handlungsfelder zur ganzheitlichen Komplexitätsbeherrschung. In: DFX 2011 proceedings of the 20nd symposium design for X. TuTech Innovation, Tutzing, pp 67-78
39. Brosch M, Krause D (2011) Design for supply chain requirements: an approach to detect the capabilities to postpone. In: Proceedings of the ASME 2011 international design engineering technical conferences and computers and information in engineering conference IDETC/CIE 2011. Washington, pp 1-9

40. Brosch M, Beckmann G, Griesbach M, Dalhöfer J, Krause D (2012) Design for value chain: towards an evaluation of global value chain complexity. In: Blecker T, Kersten W, Ringle C (eds) Managing the future supply chain: current concepts and solutions for reliability and robustness. Josef Eul, Lohmar, pp 119-135

41. Brosius F (2013) SPSS 21. mitp, Heidelberg

42. Brown K, Anderson AH, Bauer L, Berns M, Hirst G, Miller J (2006) Encyclopedia of language and linguistics, 2nd edn. Elsevier, Oxford

43. Bruce C (1994) Research students' early experiences of the dissertation literature review. Stud High Educ 19(2):217-229. doi:10.1080/03075079412331382057

44. Budde O, Golovatchev J (2011) PLM audit in the telecommunication industry. In: Thoben K-D, Stich V, Imtiaz A (eds) Proceedings of the 17th international conference on concurrent enterprising. IEEE, Aachen, pp 183-194

45. Budde O, Golovatchev J (2014) Produkte des intelligenten Markts. In: Aichele C, Doleski O (eds) Smart market. Springer, Wiesbaden, pp 593-620. doi:10.1007/978-3-658-02778-0_22

46. Buob M (2010) Verkaufskomplexität im Außendienst: Konzeption - Erfolgswirkungen - Möglichkeiten im Umgang. Gabler, Wiesbaden

47. Business Dictionary (2014) driver. Business Dictionary. http:// www.businessdictionary.com/definition/driver.html. Accessed 20 May 2015

48. Butzer S, Schötz S, Kruse A, Steinhilper R (2014) Managing complexity in remanufacturing focusing on production organisation. In: Zaeh M (ed) Enabling manufacturing competitiveness and economic sustainability: proceedings of the 5th international conference on changeable, agile, reconfigurable and virtual production (CARV 2013). Springer, Munich, pp 365-370

49. Caesar C (1991) Kostenorientierte Gestaltungsmethodik für variantenreiche Serienprodukte: Variant Mode and Effects Analysis (VMEA). VDI, Düsseldorf

50. Calinescu A, Efstathiou J, Schirn J, Bermejo J (1998) Applying and assessing two methods for measuring complexity in manufacturing. J Oper Res Soc 49(7):723-733. doi:10.1057/palgrave. jors. 2600554

51. Child P, Dietrichs R, Sanders F-H, Wisniowski S (1991) The management of complexity. McKinsey Q 28(4):52-69

52. Christ JP (2015) Intelligentes Prozessmanagement: Marktanteile ausbauen, Qualität steigern, Kosten reduzieren. Springer Gabler, Wiesbaden

53. Claeys A, Hoedt S, Soete N, van Landeghem H, Cottyn J (2015) Framework for evaluating cognitive support in mixed model assembly systems. IFAC-PapersOnLine 48(3):925-929

54. Collinson S, Jay M (2012) From complexity to simplicity: unleash your organizations's potential. Palgrave Macmillan, New York

55. Colwell B (2005) Complexity in design. IEEE Computer Soc 38(10):10-12. doi:10.1109/MC.2005.334

56. Cummings P (1991) Symptoms of complexity. McKinsey Q 28(4):60-61

57. Curran C-S, Elliger C, Rüdiger S (2008) Komplexitätsmanagement: Wann ist viel schon zu viel? Nachr Chem 56(2):160-162. doi:10.1002/nadc.200854071

58. Dalhöfer J (2009) Komplexitätsbewertung indirekter Geschäftsprozesse. Shaker, Aachen

59. Dehnen K (2004) Strategisches Komplexitätsmanagement in der Produktentwicklung. Dr. Kovac, Hamburg 
60. Deloitte (2003) Mastering complexity in global manufacturing: Powering profits and growth through value chain synchronization. Deloitte \& Touche. http://www.researchgate.net/publica tion/260414546_Mastering_Complexity_in_Global_Manufactur ing_Powering_Profits_and_Growth_through_Value_Chain_Syn chronization. Accessed 20 May 2015

61. Denk R (2007) Die $5 \alpha$ des Komplexitätsmanagements. CFO aktuell. http://www.contrast-consulting.com/fileadmin/user_ upload/press_file/Komplexitaetsmanagement_01.pdf. Accessed 20 May $201 \overline{5}$

62. Denk R, Pfneissl T (2009) Komplexitätsmanagement. Linde, Wien

63. Zeit D (2005) Das Lexikon: Mit dem Besten aus der Zeit. Band 3 Char-Dur. Zeitverlag, Hamburg

64. Dombrowski U, Herrmann C, Lacker T, Sonnentag S (2009) Modernisierung kleiner und mittlerer Unternehmen: Ein ganzheitliches Konzept. Springer, Berlin

65. Döpke S, Kress S, Kühl A (2009) Performance Measurement zur Unterstützung des Variantenmanagements: Konzeption und Implementierung eines kennzahlenorientierten Informationssystems auf Basis von SAP BI bei der KSB AG. ZWF Z Wirtsch Fabrikbetr 104(11):965-970

66. Dubislav W (1981) Die definition. Felix Meiner, Hamburg

67. Ehrenmann F (2015) Kosten- und zeiteffizienter Wandel von Produktionssystemen: Ein Ansatz für ein ausgewogenes Change Management von Produktionsnetzwerken. Springer Gabler, Wiesbaden

68. Ehrlenspiel K, Kiewert A, Lindemann U, Mörtl M (2014) Kostengünstig Entwickeln und Konstruieren: Kostenmanagement bei der integrierten Produktentwicklung, 7th edn. Springer, Berlin

69. van den Eichen S, Stahl H, Odenthal S, Vollrath C (2005) Steuern - statt reduzieren. Harv Bus Manager 27(12):114-123

70. Eigner M, Anderl R, Stark R (2012) Interdisziplinäre Produktentstehung. In: Anderl R, Eigner M, Sendler U, Stark R (eds) Smart Engineering: Interdisziplinäre Produktentstehung. Springer, Berlin, pp 7-16

71. ElMaraghy W, ElMaraghy H, Tomiyama T, Monostori L (2012) Complexity in engineering design and manufacturing. CIRP Annals - Manuf Technol 61:793-814. doi:10.1016/j.cirp.2012. 05.001

72. Erkayhan S (2011) Ein Vorgehensmodell zur automatischen Kopplung von Services am Beispiel der Integration von Standardsoftware. KIT Scientific Publishing, Karlsruhe

73. Eversheim W, Schenke F-B, Warnke L (1998) Komplexität im Unternehmen verringern und beherrschen - Optimale Gestaltung von Produkten und Produktionssystemen. In: Adam D (ed) Komplexitätsmanagement. Gabler, Wiesbaden, pp 29-46

74. F.A.Z.-Institut für Management-, Markt- und Medieninformationen GmbH (2009) Managementkompass Komplexitätsmanagement. Boschen Offsetdruck, Frankfurt am Main

75. Fässberg T, Harlin U, Garmer K, Gullander P, Fasth A, Mattsson S, Dencker K, Davidsson A, Stahre J (2011) An empirical study towards a definition of production complexity. In: Proceedings of the 21st international conference on production research. Stuttgart, pp 1-6

76. Fehling G (2002) Aufgehobene Komplexität: Gestaltung und Nutzung von Benutzungsschnittstellen. Dissertation, University of Tübingen

77. Feldhusen J, Gebhardt B (2008) Product Lifecycle Management für die Praxis: Ein Leitfaden zur modularen Einführung. Springer, Berlin

78. Fink A (2014) Conducting research literature reviews: from the internet to paper. Sage, Los Angeles

79. Fleck A (1995) Hybride Wettbewerbsstrategien: Zur Synthese von Kosten- und Differenzierungsvorteilen. Gabler, Wiesbaden
80. Flynn B, Flynn E (1999) Information-processing alternatives for coping with manufacturing environment complexity. Decis Sci 30(4):1021-1052. doi:10.1111/j.1540-5915.1999.tb00917.x

81. Franke H-J, Firchau N (2001) Variantenvielfalt in Produkten und Prozessen - Erfahrungen, Methoden und Instrumente zur erfolgreichen Beherrschung. In: VDI-Gesellschaft Entwicklung Konstruktion Vertrieb (ed) Variantenvielfalt in Produkten und Prozessen: Erfahrungen, Methoden und Instrumente. VDI, Düsseldorf, pp 1-9

82. Franke H-J, Hesselbach J, Huch B, Firchau N (2002) Variantenmanagement in der Einzel- und Kleinserienfertigung. Carl Hanser, München

83. Gabath C (2008) Gewinngarant Einkauf: Nachhaltige Kostensenkung ohne Personalabbau. Gabler, Wiesbaden

84. Geimer H (2005) Komplexitätsmanagement globaler Supply Chains. HMD - Prax. Wirtschaftsinformatik 42:38-46

85. Gell-Mann M (1994) Das Quark und der Jaguar: Vom Einfachen zum Komplexen. Piper, München

86. Gerschberger M, Engelhardt-Nowitzki C, Kummer S, Staberhofer F (2012) A model to determine complexity in supply networks. J Manuf Technol Manag 23(8):1015-1037. doi:10. $1108 / 17410381211276853$

87. Giannopoulos N (2006) Estimating the design and development cost of electronic items. Dissertation, University of Cranfield

88. Gießmann M (2010) Komplexitätsmanagement in der Logistik Kausalanalytische Untersuchung zum Einfluss der Beschaffungskomplexität auf den Logistikerfolg. Josef Eul, Lohmar

89. Gießmann M, Lasch R (2010) Der Einfluss der Beschaffungskomplexität auf den Logistikerfolg: Eine kausalanalytische Untersuchung unter Verwendung des Partial-Least-Squares (PLS) - Ansatzes. In: Bogaschewsky R, Eßig M, Lasch R, Stölzle W (eds) Supply management research: Aktuelle Forschungsergebnisse 2010. Gabler, Wiesbaden, pp 149-196

90. Gießmann M, Lasch R (2011) Komplexitätsmanagement in der Logistik: Empfehlungen für die praktische Durchführung und Umsetzung. Technische Universität Dresden. http://www.gbv. de/dms/zbw/682216739.pdf. Accessed 20 May 2015

91. Gille C (2013) Gestaltung von Produktänderungen im Kontext hybrider Produkte: Kostenanalyse am Beispiel der Groß- und Kleinserienfertigung im Maschinenbau. Springer Gabler, Wiesbaden

92. Gläser J, Laudel G (2010) Experteninterviews und qualitative Inhaltsanalyse: als Instrumente rekonstruierender Untersuchungen, 4th edn. VS Verlag, Wiesbaden

93. Göpfert J (2009) Modulare Produktentwicklung: Zur gemeinsamen Gestaltung von Technik und Organisation. Books on Demand, Norderstedt

94. Götzfried M (2013) Managing complexity induced by productvariety in manufacturing companies: complexity evaluation and integration in decision-making. Difo, Bamberg

95. Greitemeyer J, Ulrich T (2005) Umfassendes Komplexitätsmanagement - die optimale Komplexitätsbalance finden und kostengünstig halten. UNITY AG. http://unityag.de/fileadmin/ files/Fachartikel/Komplexit_tsmanagement_lang_mitLogo.pdf. Accessed 20 May 2015

96. Greitemeyer J, Meier M, Ulrich T (2008) Kampf den Folgekosten: Prozessorientiertes Lean Development. Digital Engineering Magazin. http://www.unity.de/fileadmin/files/ Fachartikel/080616_FA_JoeGr_MaMe_TU_Kampf_den_Folge kosten_DE_web.pdf. Accessed 20 May 2015

97. Grimm R, Schuller M, Wilhelmer R (2014) Portfoliomanagement in Unternehmen: Leitfaden für Manager und Investoren. Springer Gabler, Wiesbaden

98. Gronau N, Lindemann M (2009) Wandlungsfähigkeit der Produktion - von der Flexibilität zur Zukunftsfähigkeit. Ind Management 25(3):21-25 
99. Große Entrup N (2001) Komplexitätsmanagement erfordert Varianten- und Kostentransparenz. In: VDI-Gesellschaft Entwicklung Konstruktion Vertrieb (ed) Variantenvielfalt in Produkten und Prozessen: Erfahrungen, Methoden und Instrumente. VDI, Düsseldorf, pp 11-25

100. Große-Heitmeyer V, Wiendahl H-P (2004) Einführung. In: Wiendahl H-P, Gerst D, Keunecke L (eds) Variantenbeherrschung in der Montage: Konzept und Praxis der flexiblen Produktionsendstufe. Springer, Berlin, pp 3-20

101. Größler A, Grübner A, Milling P (2006) Organisational adaption processes to external complexity. Int J Oper Prod Manag 26(3):254-281. doi:10.1108/01443570610646193

102. Grote S, Kauffeld S, Frieling E (2006) Kompetenzmanagement - Grundlagen und Praxisbeispiele. Schäffer-Poeschel, Stuttgart

103. Grübner A (2007) Bewältigung markinduzierter Komplexität in der industriellen Fertigung: Theoretische Ansätze und empirische Ergebnisse des International Manufacturing Strategy Survey. Peter Lang, Frankfurt am Main

104. Grussenmeyer R, Blecker T (2010) Requirements for the design of a complexity management in new product development. In: Blecker T (ed) GIC-Prodesc proceedings of the German-Italian conference on the interdependencies between new product development and supply chain management. TuTech Innovation, Hamburg, pp 52-61

105. Gullander P, Davidsson A, Dencker K, Fasth A, Fässberg T, Harlin U, Stahre J (2011) Towards a production complexity model that supports operation, re-balancing and man-hour planning. In: Proceedings of the 4th Swedish production symposium (SPS). Lund, pp 1-10

106. Hadamitzky M (1995) Analyse und Erfolgsbeurteilung logistischer Reorganisationen. Gabler, Wiesbaden

107. Hanenkamp N (2004) Entwicklung des Geschäftsprozesses Komplexitätsmanagement in der kundenindividuellen Serienfertigung - Ein Beitrag zum Informationsmanagement in mehrdimensional modellierten Produktionssystemen. Shaker, Aachen

108. Hasenpusch J, Moos C, Schwellbach U (2004) Komplexität als Aktionsfeld industrieller Unternehmen. In: Maier F (ed) Komplexität und Dynamik als Herausforderung für das Management. Deutscher Universitäts-Verlag, Wiesbaden, pp 131-154

109. Haumann M, Westermann H-H, Seifert S, Butzer S (2012) Managing complexity: a methodology, exemplified by the industrial sector of remanufacturing. In: Björkman M (ed) Proceedings of the 5 th international swedish production symposium SPS 12. Swedish Production Academy, Linköping, pp 107-114

110. Hauptmann S (2007) Gestaltung des Outsourcings von Logistikleistungen: Empfehlungen zur Zusammenarbeit zwischen verladenden Unternehmen und Logistikdienstleistern. Deutscher Universitäts-Verlag, Wiesbaden

111. Heina J (1999) Variantenmanagement: Kosten-Nutzen-Bewertung zur Optimierung der Variantenvielfalt. Deutscher Universitäts-Verlag, Wiesbaden

112. Helfrich C (2009) Das Prinzip Einfachheit: Reduzieren Sie die Komplexität. Expert, Renningen

113. Henning K, Borowski E (2014) Managementkybernetik und Umgang mit Unsicherheiten. In: Schuh G, Stich V (eds) Enterprise-integration. Springer, Berlin, pp 45-62. doi:10.1007/ 978-3-642-41891-4_5

114. Hering N, Schürmeyer M, Groten M, Schenk M (2012) Kostentreiber im Auftragsabwicklungsprozess identifizieren: Optimierungsprojekt weist Wege zu effizienteren Abläufen auf. $\mathrm{f}+\mathrm{h} 10: 10-11$

115. Herrmann C (2010) Ganzheitliches Life Cycle Management: Nachhaltigkeit und Lebenszyklusorientierung in Unternehmen. Springer, Heidelberg
116. Heydari B, Dalili K (2012) Optimal system's complexity: an architecture perspective. Proc Comput Sci 12:63-68. doi:10. 1016/j.procs.2012.09.030

117. Hoffmann S (2000) Variantenmanagement aus Betreibersicht: Das Beispiel einer Schienenverkehrsunternehmung. Gabler, Wiesbaden

118. Höge R (1995) Organisatorische Segmentierung: Ein Instrument zur Komplexitätshandhabung. Gabler, Wiesbaden

119. Huber S (2014) Informationsintegration in dynamischen Unternehmensnetzwerken: Architektur, Methode und Anwendung. Springer Gabler, Wiesbaden

120. Isik F (2010) An entropy-based approach for measuring complexity in supply chains. Int J Prod Res 48(12):3681-3696. doi:10.1080/00207540902810593

121. Isik F (2011) Complexity in supply chains: a new approach to quantitative measurement of the supply-chain-complexity. In: Li $P$ (ed) Supply chain management. InTech, Shanghai, pp 417-432

122. Jania T (2004) Änderungsmanagement auf Basis eines integrierten Prozess- und Produktdatenmodells mit dem Ziel einer durchgängigen Komplexitätsbewertung. Dissertation, University of Paderborn

123. Jäger J, Kluth A, Sauer M, Schatz A (2013) Komplexitätsbewirtschaftung: Die neue Managementdisziplin in Produktion und Supply Chain. ZWF Z Wirtsch Fabrikbetr 108(5):341-343

124. Jensen TC, Bekdik B, Thuesen C (2014) Understanding complex construction systems through modularity. In: Brunoe TD, Nielsen K, Joergensen KA, Taps SB (eds) Proceedings of the 7th world conference on mass customization, personalization, and co-creation (MCPC 2014): twenty years of mass customization-towards new frontiers. Springer, Cham, pp 541-556. doi:10.1007/978-3-319-04271-8_45

125. Kaiser A (1995) Integriertes Variantenmanagement mit Hilfe der Prozesskostenrechnung. Rosch-Buch, Hallstadt

126. Kaluza B, Bliem H, Winkler H (2006) Strategies and metrics for complexity management in supply chains. In: Blecker T, Kersten W (eds) Complexity management in supply chains: concepts, tools and methods. Erich Schmidt, Berlin, pp 3-19

127. Kersten W (2011) Je komplexer, desto teurer und risikoreicher. io management, September/October, pp 14-19

128. Kersten W, Koppenhagen F, Meyer C (2004) Strategisches Komplexitätsmanagement durch Modularisierung in der Produktentwicklung. In: Spath D (ed) Forschungs- und Technologiemanagement: Potenziale nutzen - Zukunft gestalten. Carl Hanser, München, pp 211-218

129. Kersten W, Rall K, Meyer C, Dalhöfer J (2006) Complexity management in logistics and ETO-supply chains. In: Blecker T, Kersten W (eds) Complexity management in supply chains: concepts, tools and methods. Erich Schmidt, Berlin, pp 325-342

130. Kersten W, Lammers T, Skride H (2012) Komplexitätsanalyse von Distributionssystemen. Technical University of HamburgHarburg. https://www.bvl.de/files/441/481/Sachbericht_16164. pdf. Accessed 20 May 2015

131. Kestel R (1995) Variantenvielfalt und Logistiksysteme: Ursachen - Auswirkungen - Lösungen. Gabler, Wiesbaden

132. Keuper F (2004) Kybernetische Simultaneitätsstrategie: Systemtheoretisch-kybernetische Navigation im Effektivitäts- Effizienz-Dilemma. Logos, Berlin

133. Kim J, Wilemon D (2003) Sources and assessment of complexity in NPD projects. R\&D Manag 33(1):15-30. doi:10.1111/ 1467-9310.00278

134. Kirchhof R (2003) Ganzheitliches Komplexitätsmanagement Grundlagen und Methodik des Umgangs mit Komplexität im Unternehmen. Deutscher Universitäts-Verlag, Wiesbaden 
135. Kirsch J (2009) Organisation der Bauproduktion nach dem Vorbild industrieller Produktionssysteme: Entwicklung eines Gestaltungsmodells eines Ganzheitlichen Produktionssystems für den Bauunternehmer. Universitätsverlag, Karlsruhe

136. Klabunde S (2003) Wissensmanagement in der integrierten Produkt- und Prozessgestaltung: Best-Practice-Modelle zum Management von Meta-Wissen. Deutscher Universitäts-Verlag, Wiesbaden

137. Klagge C, Blank J (2012) Komplexität als Chance nutzen. Wassermann AG http://www.wassermann.de/fileadmin/user_ upload/deutsch/dokumente/pdf/WAG_Broschueren/White_Paper_ 2012_Komplexitaetsmanagement.pdf. Accessed 20 May 2015

138. Klaus P (2004) Die Frage der optimalen Komplexität in SupplyChains und Supply Netzwerken. In: Eßig K (ed) Perspektiven des Supply Management - Konzepte und Anwendungen. Springer, Berlin, pp 362-375

139. Kleijnen JPC (2009) Factor screening in simulation experiments: review of sequential bifurcation. In: Alexopoulos C, Goldsman D, Wilson JR (eds) Advancing the frontiers of simulation: a festschrift in honor of George Samuel Fishman. Springer, Dordrecht, pp 153-168

140. Klepsch B (2004) Komplementäre Produkt- und Fabrikmodularisierung am Beispiel der Automobilindustrie. VDI, Düsseldorf

141. Klinkne R, Mayer A, Thom A (2005) Modulare Logistik: Ein Lösungskonzept zum Management von Komplexität in dynamischen Netzwerken. Ind Manag 21(5):33-36

142. Klug F (2010) Logistikmanagement in der Automobilindustrie: Grundlagen der Logistik im Automobilbau. Springer, Heidelberg

143. Kohagen J (2007) Auslastung behindert Kanbanprozess. DVZ Dtsch. Verkehrs-Ztg, 25 October

144. Kolbusa M (2013) Implementation management: high-speed strategy implementation. Springer, Heidelberg

145. Kolbusa M (2013) Umsetzungsmanagement: Wieso aus guten Strategien und Veränderungen häufig nichts wird. Springer Gabler, Wiesbaden

146. Komorek C (1998) Integrierte Produktentwicklung: Der Entwicklungsprozess in mittelständischen Unternehmen der metallverarbeitenden Serienfertigung. Steuer- und Wirtschaftsverlag, Berlin

147. Köster O (1998) Komplexitätsmanagement in der Industrie Kundennähe und Effizienz in der Leistungserstellung. Deutscher Universitäts-Verlag, Wiesbaden

148. Krah E (2014) Komplexitätsmanagement. http://ekrah.com/ wiki/Komplexit\%C3\%A4tsmanagement. Accessed 15 Oct 2014

149. Krause F-L, Franke H-J, Gausemeier J (2007) Innovationspotenziale in der Produktentwicklung. Carl Hanser, München

150. Krizanits J (2015) Der Tanz mit der Komplexität: Tools für Teams. ZOE Z. Organ. Entwickl. 4:42-49

151. Krumm S, Schopf K (2005) Komplexität beherrschen. In: VDI (Ed.) Logistik-Navigator für komplexe Netzwerke?: Proceedings of the 6th annual conference on automotive logistics. VDI, Leipzig, pp 230-235

152. Kuckartz U (2012) Qualitative Inhaltsanalyse: Methoden, Praxis. Computerunterstützung, Beltz Juventa, Weinheim

153. Kühl S (1995) Vom Mythos der flachen Organisation: Warum Reengineering und Enthierarchisierung in Unternehmen scheitern. Blick Wirtsch, 28 March, p 7

154. Lammers T (2012) Komplexitätsmanagement für Distributionssysteme. Josef Eul, Lohmar

155. Lasch R, Gießmann M (2009) Ganzheitliche Ansätze zum Komplexitätsmanagement - eine kritische Würdigung aus Sicht der Beschaffungslogistik. In: Bogaschewsky R, Eßig M, Lasch
R, Stölzle W (eds) Supply Management Research: Aktuelle Forschungsergebnisse 2008. Gabler, Wiesbaden, pp 194-231

156. Lasch R, Gießmann M (2009) Qualitäts- und Komplexitätsmanagement - Parallelitäten und Interaktionen zweier Managementdisziplinen. In: Hünerberg R, Mann A (eds) Ganzheitliche Unternehmensführung in dynamischen Märkten. Gabler, Wiesbaden, pp 93-124

157. Lebedynska Y (2011) Entwicklung eines Informationssystems mit Reifegradmanagement für automatisierte Schraubprozesse. Dissertation, Brandenburg University of Technology, Cottbus Senftenberg

158. de Leeuw S, Grotenhuis R, van Goor R (2013) Assessing complexity of supply chains: evidence from wholesalers. Int $\mathbf{J}$ Oper Prod Manag 33(8):960-980. doi:10.1108/IJOPM-07-20120258

159. Lindemann M, Gronau N (2009) Gestaltung marktorientierter Produktionssysteme. In: Specht D (ed) Weiterentwicklung der Produktion: Tagungsband der Herbsttagung 2008 der Wissenschaftlichen Kommission Produktionswirtschaft im VHG. Gabler, Wiesbaden, pp 43-60

160. Lindemann U, Maurer M, Braun T (2009) Structural complexity management: an approach for the field of product design. Springer, Berlin

161. Link P (2014) Agile Methoden im Produkt-Lifecycle-Prozess Mit agilen Methoden die Komplexität im Innovationsprozess handhaben. In: Schoeneberg K-P (ed) Komplexitätsmanagement in Unternehmen: Herausforderungen im Umgang mit Dynamik, Unsicherheit und Komplexität meistern. Springer Gabler, Wiesbaden, pp 65-92

162. Lucae S, Rebentisch E, Oehmen J (2014) Understanding the front-end of large-scale engineering programs. Proc Comput Sci 28:653-662. doi:10.1016/j.procs.2014.03.079

163. Luhmann N (1980) Komplexität. In: Grochla E (ed) Enzyklopädie der Betriebswirtschaftslehre: Handwörterbuch der Organisation. Poeschel, Stuttgart, pp 1064-1070

164. Lübke E (2007) Lebenszyklusorientiertes Produktstrukturmanagement: Eine theoretische und empirische Untersuchung. Transfer-Centrum, München

165. Mahmood W, Rosdi M, Muhamad M (2014) Formulating the strategy in managing manufacturing complexity: a pre-review. Sci Int (Lahore) 26(5):1849-1853

166. Manuj I, Sahin F (2011) A model of supply chain and supply chain decision-making complexity. Int J Phys Distrib Logist Manag 41(5):511-549. doi:10.1108/09600031111138844

167. Mansour M (2006) Informations- und Wissensbereitstellung für die lebenszyklusorientierte Produktentwicklung. Vulkan, Essen

168. Marti M (2007) Complexity management: optimizing product architecture of industrial products. Deutscher UniversitätsVerlag, Wiesbaden

169. Maschinenmarkt (2006) Komplexität beherrschen. http://www. maschinenmarkt.vogel.de/themenkanaele/managementundit/ein kauf/articles/16433/. Accessed 15 Oct 2014

170. Mayer A (2007) Modularisierung der Logistik: Ein Gestaltungsmodell zum Management von Komplexität in der industriellen Logistik. Universitätsverlag der Technischen Universität Berlin, Berlin

171. Meier H, Hanenkamp N (2003) Integriertes Komplexitätsmanagement mit digitalisierten Produktionsmodellen. Ind. Manag 19(1):9-12

172. Meijer B (2006) Organization structures for dealing with complexity. Dissertation, Technical University of Delft, Delft

173. Meredith J (1993) Theory building through conceptual methods. Int J Oper Prod Manag 13(5):3-11

174. Meyer C (2007) Integration des Komplexitätsmanagements in den strategischen Führungsprozess der Logistik. Haupt, Bern 
175. Meyer J, Brunner A (2007) Einflüsse analysieren. Logist. Heute 29(9):32-33

176. Minhas S, Lehmann C, Berger U (2011) Concept and development of intelligent production control to enable versatile production in the automotive factories of the future. In: Hesselbach J, Herrmann C (eds) Glocalized Solutions for Sustainability in Manufacturing: proceedings of the 18th CIRP international conference on life cycle engineering. Springer, Berlin, pp 57-62. doi:10.1007/978-3-642-19692-8_10

177. Miragliotta G, Perona M, Portioli-Staudacher A (2002) Complexity management in the supply chain: theoretical model and empirical investigation in the italian household appliance industry. In: Seuring $\mathrm{S}$ (ed) Cost management in supply chains. Springer, Berlin, pp 381-397

178. Moos C (2009) Komplexität, Flexibilität und Erfolg als Herausforderungen marktorientierter Fertigungsstrategien. In: Strohhecker J, Größler A (eds) Strategisches und operatives Produktionsmanagement. Gabler, Wiesbaden, pp 47-69

179. Nurcahya E (2009) Ein Produktdatenmodell für rechnerunterstütztes Variantenmanagement. Shaker, Aachen

180. Olbrich R, Battenfeld D (2000) Komplexitätsmanagement aus Sicht des Marketing und der Kostenrechnung. Hagen University. https://www.fernuni-hagen.de/marketing/download/forschungsbe richte/fb03_web.pdf. Accessed 20 May 2015

181. Ortner W, Hanusch S, Schweiger J (2011) Management of Requirements in Collaborations ${ }^{\mathrm{MRC}}$ - Das Projekt. In: Ortner W, Hanusch S, Tschandl M (eds) Abnehmer-LieferantenBeziehungen optimieren: management of requirements in collaborations. Leykam, Graz, pp 1-10

182. Oxford Dictionaries (2014) Complex. http://www.oxforddic tionaries.com/definition/english/complex. Accessed 13 Nov 2014

183. Oxford Learner's Dictionaries (2016) dimension. http://www. oxfordlearnersdictionaries.com/definition/english/dimension?q= dimension. Accessed 1 July 2016

184. Oxford Learner's Dictionaries (2016) factor. http://www.oxfor dlearnersdictionaries.com/definition/english/factor_1?q=factor. Accessed 1 July 2016

185. Oxford Learner's Dictionaries (2016) force. http://www.oxfor dlearnersdictionaries.com/definition/english/force_1\#force_1_4. Accessed 1 July 2016

186. Oxford Learner's Dictionaries (2016) indicator. http://www. oxfordlearnersdictionaries.com/definition/english/indicator?q= indicator. Accessed 1 July 2016

187. Oxford Learner's Dictionaries (2016) parameter. http://www. oxfordlearnersdictionaries.com/definition/english/parameter?q= parameter. Accessed 1 July 2016

188. Oxford Learner's Dictionaries (2016) phenomenon. http://www. oxfordlearnersdictionaries.com/definition/english/phenomenon? $\mathrm{q}=$ phenomenon. Accessed 1 July 2016

189. Oxford Learner's Dictionaries (2016) property. http://www.oxfor dlearnersdictionaries.com/definition/english/property\#property_4. Accessed 1 July 2016

190. Oxford Learner's Dictionaries (2016) source. http://www.oxfor dlearnersdictionaries.com/definition/english/source_1?q=source. Accessed 1 July 2016

191. Oxford Learner's Dictionaries (2016) symptom. http://www. oxfordlearnersdictionaries.com/definition/english/symptom?q= symptom. Accessed 1 July 2016

192. Oxford Learner's Dictionaries (2016) variable. http://www. oxfordlearnersdictionaries.com/definition/english/variable_1?q= variable. Accessed 1 July 2016

193. Oyama K, Learmonth G, Chao R (2015) Applying complexity science to new product development: modeling considerations, extensions, and implications. J Eng Technol Manag 35:1-24. doi:10.1016/j.jengtecman.2014.07.003
194. Parry G, Purchase V, Mills J (2011) Complexity Management. In: Ng I, Parry G, Wild P, McFarlane D, Tasker P (eds) Complex Engineering Service Systems: Concepts and Research. Springer, London, pp 67-86. doi:10.1007/978-0-85729-189-9_4

195. Patzak G (1982) Systemtechnik - Planung komplexer innovativer Systeme: Grundlagen, Methoden, Techniken. Springer, Berlin

196. Payne G, Payne J (2004) Key concepts in social research. SAGE, London

197. Pepels W (2003) Produktmanagement: Produktinnovation, Markenpolitik, Programmplanung. Oldenbourg Wissenschaftsverlag, München, Prozessorganisation

198. Perona M, Miragliotta G (2004) Complexity management and supply chain performance assessment: a field study and a conceptual framework. Int J Prod Econ 90:103-115. doi:10.1016/ S0925-5273(02)00482-6

199. Pfeifer W et al (1989) Etymologisches Wörterbuch des Deutschen. Akademie-Verlag, Berlin

200. Picot A, Freudenberg H (1998) Neue organisatorische Ansätze zum Umgang mit Komplexität. In: Adam D (ed) Komplexitätsmanagement. Gabler, Wiesbaden, pp 69-86

201. Piller F (2006) Mass customization: Ein wettbewerbsstrategisches Konzept im Informationszeitalter. Deutscher UniversitätsVerlag, Wiesbaden

202. Piller F, Waringer D (1999) Modularisierung in der Automobilindustrie - neue Formen und Prinzipien: Modular Sourcing, Plattformkonzept und Fertigungssegmentierung als Mittel des Komplexitätsmanagements. Shaker, Aachen

203. Prillmann M (1996) Management der Variantenvielfalt: Ein Beitrag zur handlungsorientierten Erfolgsfaktorenforschung im Rahmen einer empirischen Studie in der Elektroindustrie. Peter Lang, Frankfurt am Main

204. Puhl H (1999) Komplexitätsmanagement - Konzept zur ganzheitlichen Erfassung. Planung und Regelung der Komplexität in Unternehmensprozessen, Foto-Repro-Druck, Kaiserslautern

205. Purle E (2004) Management von Komplexität in jungen Wachstumsunternehmen: Eine fallstudiengestützte Analyse. Josef Eul, Lohmar

206. Rall K, Dalhöfer J (2004) Komplexität indirekter Prozesse bei der Erstellung variantenreicher Produkte. ZWF Z Wirtsch Fabrikbetr 99(11):623-630

207. Rao K, Young R (1994) Global supply chains: factors influencing outsourcing of logistics functions. Int J Phys Distrib Logist Manag 24(6):11-19. doi:10.1108/09600039410066141

208. Raufeisen M (1997) Komplexitätsreduktion in der Auftragsabwicklung. ZfB Z Betriebswirtsch 67(2):125-149

209. Raufeisen M (1999) Konzept zur Komplexitätsmessung des Auftragsabwicklungsprozesses: Eine empirische Untersuchung. Transfer-Centrum, München

210. Reiners F, Sasse A (1999) Komplexitätskostenmanagement. Z Controll Account Syst Anwend 43(4):222-232

211. Reiß M (1992) Optimierung der Unternehmenskomplexität. io management 61(7/8):40-43

212. Reiß M (1993) Komplexitätsmanagement (I). In: Sieben G, Woll A (eds) WISU - Das Wirtschaftsstudium: Zeitschrift für Ausbildung, Examen und Kontaktstudium, Jahresregister '93. Lange \& Werner, Düsseldorf, pp 54-59

213. Reiß M (1993) Komplexität beherrschen durch Orga-Tuning. In: Reiß M (ed) Komplexität meistern - Wettbewerbsfähigkeit sichern. Schäffer-Poeschel, Stuttgart, pp 1-41

214. Reuter C, Prote J-P, Stöwer M (2015) Komplexität in Produktionsnetzwerken: bewertung der Komplexitätsveränderung bei Anpassung der Anzahl von Produktionsstandorten. Ind. 4.0. Management 31:8-12

215. Riedl R (2000) Strukturen der Komplexität: Eine Morphologie des Erkennens und Erklärens. Springer, Berlin 
216. Rosemann M (1998) Die Komplexitätsfalle. Logist Heute 20(9):60-62

217. Rudzio H, Apitz R, Denkena B (2006) Visionen für die Fertigung - Einfach produktiv sein. Ind Management 22(1):51-54

218. Ruppert T (2007) Modularisierung des Verbrennungsmotors. University Press, Kassel

219. Saunders M, Lewis P, Thornhill A (2009) Research methods for business students. Pearson, Harlow

220. Sauter R (2014) Steuerung im komplexen und dynamischen Marktumfeld - Eine Einführung. In: Keuper F, Sauter R (eds) Unternehmenssteuerung in der produzierenden Industrie: Konzepte und Best Practices. Springer Gabler, Wiesbaden, pp 4-25

221. Schäfer H, Henning K (1991) Hilfsmittel zur Komplexitätsbewältigung im Tagesgeschäft von Container-Umschlaganlagen. In: Henning K, Harendt B (eds) Methodik und Praxis der Komplexitätsbewältigung: Wissenschaftliche Jahrestagung der Gesellschaft für Wirtschaft- und Sozialkybernetik am 4. und 5. Oktober 1991 in Aachen. Duncker \& Humblot, Berlin, pp 155-168

222. Schawel C, Billing F (2011) Top 100 management tools: Das wichtigste Buch eines Managers. Gabler, Wiesbaden

223. Scheiter S, Scheel O, Klink G (2008) Was kostet Komplexität wirklich? A.T. Kearney

224. Schließmann C (2010) Komplexe Systeme brechen wie Glas. Die Bank 6:56-59

225. Schmid T (2009) Variantenmanagement - Lösungsansätze in den einzelnen Phasen des Produktlebenszyklus zur Beherrschung von Variantenvielfalt. Diplomica, Hamburg

226. Schmidt A (2015) Überlegene Geschäftsmodelle: Wertgenese und Wertabschöpfung in turbulenten Umwelten. Springer Gabler, Wiesbaden. doi:10.1007/978-3-658-08656-5

227. Schmidt D (1992) Strategisches Management komplexer Systeme: Die Potentiale computergestützter Simulationsmodelle als Instrumente eines ganzheitlichen Managements - dargestellt am Beispiel der Planung und Gestaltung komplexer Instandhaltungssysteme. Peter Lang, Frankfurt am Main

228. Schmidt S (2009) Die Diffusion komplexer Produkte und Systeme: Ein systemdynamischer Ansatz. Gabler Verlag, Wiesbaden

229. Schmidt C, Wienholdt H, Vorspel-Rüter M (2008) Komplexitätsorientierte Gestaltung von Produktionssystemen: Flexible Konfigurationslogik für die Fertigung kundenindividueller Produkte zu Kosten der Massenproduktion. ZWF Z Wirtsch Fabrikbetr 103(12):841-844

230. Schmitt R, Vorspel-Rüter M, Wienholdt H (2010) Handhabung von Komplexität in flexiblen Produktionssystemen: Kundenindividuelle Produkte zu Kosten der Massenproduktion. Ind Management 26(1):53-56

231. Schmitz C (2015) Klasse statt Masse. acquisa (5):64-69

232. Schömann S (2012) Produktentwicklung in der Automobilindustrie: Managementkonzepte vor dem Hintergrund gewandelter Herausforderungen. Gabler, Wiesbaden

233. Schoeneberg K-P (2014) Komplexität - Einführung in die Komplexitätsforschung und Herausforderung für die Praxis. In: Schoeneberg K-P (ed) Komplexitätsmanagement in Unternehmen: Herausforderungen im Umgang mit Dynamik, Unsicherheit und Komplexität meistern. Springer Gabler, Wiesbaden, pp 13-28

234. Schönsleben P (2011) Integrales Logistikmanagement: Operations und Supply Chain Management innerhalb des Unternehmens und unternehmensübergreifend, 6th edn. Springer, Heidelberg

235. Schott P, Horstmann F, Bodendorf F (2015) Context specific complexity management - a recommendation model for optimal corporate complexity. Int J Bus Sci Appl Manag 10(2):32-46
236. Schöttl F, Herrmann N, Maurer M, Lindemann U (2014) Systematic procedure for handling complexity in the automotive prodution. In: Zaeh M (ed) Enabling manufacturing competitiveness and economic sustainability: proceedings of the 5th international conference on changeable, Agile, Reconfigurable and virtual production (CARV 2013). Springer, Munich, pp 255-260

237. Schubert S (2008) Wettbewerbsvorteile durch Vereinheitlichung am Beispiel der europäischen Schienenfahrzeugindustrie. Dissertation, University of Halle-Wittenberg

238. Schuh C, Kromoser R, Strohmer M, Romero Pérez R, Triplat A (2011) Der agile Einkauf: Erfolgsgarant in volatilen Zeiten. Gabler, Wiesbaden

239. Schuh G, Schwenk U (2001) Produktkomplexität managen Strategien, Methoden. Tools, Carl Hanser, München

240. Schuh G (2005) Produktkomplexität managen - Strategien, Methoden, Tools, 2nd edn. Carl Hanser, München

241. Schuh G, Sauer A, Döring S (2006) Komplexitätsorientierte Gestaltung von Kooperationen: Eine Chance zur Sicherung des Standorts Deutschland. Ind Management 22(3):72-74

242. Schuh G, Arnoscht J, Rudolf S (2010) Integrated development of modular product platforms. In: Kocaoglu DF, Anderson TR, Daim $\mathrm{T}$ (eds) Proceedings of international center for management of engineering and technology PICMET. Portland, IEEE, pp 1928-1940

243. Schuh G, Krumm S, Amann W (2013) Chefsache Komplexität: Navigation für Führungskräfte. Springer Gabler, Wiesbaden

244. Schuh G, Gartzen T, Wagner J (2015) Complexity-oriented ramp-up of assembly systems. CIRP J Manuf Sci Technol 10:1-15. doi:10.1016/j.cirpj.2015.05.007

245. Schuh G, Guo D, Hoppe M, Ünlü V (2014) Steuerung der Lieferantenbasis. In: Schuh G (ed) Einkaufsmanagement, 2nd edn. Springer, Berlin, pp 255-342

246. Schuh G, Hoppe M, Schubert J, Mangoldt J (2014) Lieferantenauswahl. In: Schuh G (ed) Einkaufsmanagement, 2nd edn. Springer, Berlin, pp 183-254

247. Schuh G, Potente T, Varandani R, Witthohn C (2014) Consideration of risk management in global production footprint design. Proc CIRP 17:345-350. doi:10.1016/j.procir.2014.01. 048

248. Schulte C (1992) Komplexitätsmanagement. In: Schulte C (ed) Effektives Kostenmanagement: Methoden und Implementierung. Schäffer-Poeschel, Stuttgart, pp 83-94

249. Schulte C (1995) Komplexitätsmanagement. In: Corsten H, Reiß M (eds) Handbuch Unternehmensführung: Konzepte - Instrumente - Schnittstellen. Gabler, Wiesbaden, pp 757-766

250. Schwandt A, Franklin JR (2010) Logistics: the backbone for managing complex organizations. Haupt, Bern

251. Schweiger S (2005) Potenziale heben. Logist Heute 27(11):40-42

252. Schwenk-Willi U (2001) Integriertes Komplexitätsmanagement: Anleitung und Methodik für die produzierende Industrie auf Basis einer typologischen Untersuchung. Difo, Bamberg

253. Scott C, Lundgren H, Thompson P (2011) Guide to supply chain management. Springer, Heidelberg

254. Seifert S, Butzer S, Westermann H-H, Steinhilper R (2013) Managing complexity in remanufacturing. In: Proceedings of the world congress on engineering 2013 Vol. I WCE 2013. London, pp 647-652

255. Serdarasan S (2011) A review of supply chain complexity drivers. In: Proceedings of the 41 st international conference on computers and industrial engineering. Los Angeles, pp 792-797

256. Serdarasan S (2013) A review of supply chain complexity drivers. Comput Ind Eng 66:533-540. doi:10.1016/j.cie.2012.12. 008 
257. Servatius H-G (2010) Gestaltung von interaktiven Strategieprozessen im Enterprise 2.0. Inf Management Consult 25(4):6-13

258. Shah A. (2015) Literature survey vs. literature review. https://www. researchgate.net/post/What_is_the_main_difference_between_ Literature_Survey_and_Literature_Review. Accessed 9 July 2016

259. Siebertz K, van Bebber D, Hochkirchen T (2010) Statistische Versuchsplanung: design of experiments (DoE). Springer, Berlin

260. Skride H (2015) Kostenorientierte Bewertung modularer Produktarchitekturen. Josef Eul, Lohmar

261. Stark G, Oman P (1995) A survey instrument for understanding the complexity of software maintenance. Softw Maint Res Pract 7(12):421-441. doi:10.1002/smr.4360070605

262. Stauder J, Buchholz S, Klocke F, Mattfeld P (2014) A new framework to evaluate the process capability of production technologies during production ramp-up. Proc CIRP 20:126-131. doi:10.1016/j.procir.2014.05.043

263. Steger U, Amann W, Maznevski M (2007) Managing complexity in global organizations. Wiley, Chichester

264. Steinhilper R, Westermann H-H, Butzer S, Haumann M, Seifert S (2012) Komplexität messbar machen: Eine Methodik zur Quantifizierung von Komplexitätstreibern und -wirkungen am Beispiel der Refabrikation. ZWF Z Wirtsch Fabrikbetr 107(5):360-365

265. Stich V, Kompa S, Meier C, Cuber S (2011) Produktion am Standort Deutschland: Faktoren für eine nachhaltige Wettbewerbssicherung. ZWF Z Wirtsch Fabrikbetr 106(11):855-860

266. Sun C, Rose T (2015) Supply chain complexity in the semiconductor industry: assessment from system view and the impact of changes. IFAC PapersOnLine 48(3):1210-1215. doi:10.1016/j.ifacol.2015.06.249

267. Tenhiälä A (2009) Contingency theories of order management, capacity planning, and exception processing in complex manufacturing environments. Dissertation, Helsinki University of Technology

268. Thiebes F, Plankert N (2014) Umgang mit Komplexität in der Produktentwicklung - Komplexitätsbeherrschung durch Variantenmanagement. In: Schoeneberg K-P (ed) Komplexitätsmanagement in Unternehmen: Herausforderungen im Umgang mit Dynamik, Unsicherheit und Komplexität meistern. Springer Gabler, Wiesbaden, pp 165-186

269. Ulrich H (1970) Die Unternehmung als produktives soziales System: Grundlagen der allgemeinen Unternehmungslehre. Haupt, Bern/Stuttgart

270. Vickers P, Kodarin A (2006) Deriving benefit from supply chain complexity: complexity can be an important source of competitive advantage-provided you know how to manage it. PRTM

271. Vizjak A, Schiffers E (1996) Zu Viele, zu detaillierte und zu häufige Berichte. Blick Wirtsch 23:9

272. Vogel W, Lasch R (2015) Approach for complexity management in variant-rich product development. In: Blecker T, Kersten W, Ringle CM (eds) Operational excellence in logistics and supply chains: proceedings of the hamburg international conference of logistics (HICL). Hamburg, pp 97-140

273. von Waldthausen C (2007) Vertrieb komplexer Produkte: Vertriebsorganisation zwischen Gesamtkundenverantwortung und Produktexpertise. Rainer Hampp, München

274. Wallner M, Brunner U, Zsifkovits H (2015) Modelling complex planning processes in supply chains. In: Blecker T, Kersten W, Ringle CM (eds) Operational excellence in logistics and supply chains: proceedings of the hamburg international conference of logistics (HICL). Hamburg, pp 3-30
275. von Wangenheim S (1998) Planung und Steuerung des Serienanlaufs komplexer Produkte: Dargestellt am Beispiel der Automobilindustrie. Europäischer Verlag der Wissenschaften, Frankfurt am Main

276. Warnecke G, Puhl H (1997) Komplexitätsmanagement - Mit Systemdenken zur Beherrschung der Komplexität. wt Werkstattstech. 87:359-363

277. Wassmus A (2014) Serviceorientierung als Erfolgsfaktor und Komplexitätstreiber beim Angebot hybrider Produkte. Springer Gabler, Wiesbaden

278. Weber J (1994) Logistik-Kennzahlen. Handelsblatt (203), 20 October, $\mathrm{p} 24$

279. Wegehaupt P (2004) Führung von Produktionsnetzwerken. Dissertation, University of Aachen

280. Westphal J (2000) Komplexitätsmanagement in der Produktionslogistik. Technische Universität Dresden. http://tu-dresden. de/die_tu_dresden/fakultaeten/vkw/iwv/diskuss/2000_4_diskusbtr_ ivw.pdf. Accessed 20 May 2015

281. Wildemann H (1995) Komplexitätsmanagement in der Fabrikorganisation. ZWF Z Wirtsch Fabrikbetr 90(1-2):21-26

282. Wildemann H (1998) Komplexitätsmanagement durch Prozessund Produktgestaltung. In: Adam D (ed) Komplexitätsmanagement. Gabler, Wiesbaden, pp 47-68

283. Wildemann H (1999) Ansätze für Einsparpotentiale. Logist Heute 21(4):64-67

284. Wildemann H (1999) Komplexität: Vermeiden oder beherrschen lernen. Harv Bus Manag 21(6):31-42

285. Wildemann H (2005) Teure Vielfalt: Wie Komplexitätsmanagement auch Qualitätskosten reduziert. QZ 50(11):33-36

286. Wildemann H (2007) Supply Chain Management. In: Köhler R, Küpper H-U, Pfingsten A (eds) Handwörterbuch der Betriebswirtschaft. Schäffer-Poeschel, Stuttgart, pp 1721-1730

287. Wildemann H (2009) Produkte \& Services entwickeln und managen, 2nd edn. Transfer-Centrum, München

288. Wildemann H (2011) Variantenmanagement: Leitfaden zur Komplexitätsreduzierung, -beherrschung und -vermeidung, 19th edn. Transfer-Centrum, München

289. Wildemann H, Voigt K-I (2011) Komplexitätsindex-Tool: Entscheidungsgrundlagen für die Produktprogrammgestaltung bei KMU. Transfer-Centrum, München

290. Wildemann H (2012) Komplexitätsmanagement in Vertrieb, Beschaffung, Produkt, Entwicklung und Produktion, 13th edn. Transfer-Centrum, München

291. Wulf S, Redlich T, Wulfsberg JP (2015) Die Strategie der Offenheit in der industriellen Wertschöpfung. ZWF Z Wirtsch Fabrikbetr 110(3):107-113

292. Zahn E, Kapmeier F, Tilebein M (2006) Formierung und Evolution von Netzwerken - ausgewählte Erklärungsansätze. In: Wojda F, Barth A (eds) Innovative Kooperationsnetzwerke. Gabler, Wiesbaden, pp 129-150

293. Zhang Y-L, Yang N-D (2012) Research on the evolutionary mechanism of NPD project complexity based on the CAS theory. In: Lan H, Yang Y-H (eds) Proceedings of the 19th international conference on management science \& engineering. Dallas, University of Texas \& Harbin Institute of Technology, IEEE, pp 230-235. doi:10.1109/ICMSE.2012.6414188

294. Zimmermann K, Fabisch N (2014) Personalmarketing als Baustein eines Komplexitätsmanagements in der logistischen Personalbeschaffung. In: Schoeneberg K-P (ed) Komplexitätsmanagement in Unternehmen: Herausforderungen im Umgang mit Dynamik, Unsicherheit und Komplexität meistern. Springer Gabler, Wiesbaden, pp 249-274 